UNIVERSIDADE DE SÃO PAULO

FACULDADE DE FILOSOFIA, LETRAS E CIÊNCIAS HUMANAS DEPARTAMENTO DE LETRAS CLÁSSICAS E VERNÁCULAS PROGRAMA DE PÓS-GRADUAÇÃO EM ESTUDOS COMAPRADOS DE LITERATURAS EM LÍNGUA PORTUGUESA

DAVIANE MOREIRA E SILVA

\title{
NO RITMO DA LAPASSIADA: LEITURAS DO PROJETO CRÍTICO-LITERÁRIO DE EDIMILSON DE ALMEIDA PEREIRA
}

São Paulo

2014 
DAVIANE MOREIRA E SILVA

\section{NO RITMO DA LAPASSIADA \\ Leituras do projeto crítico-poético de Edimilson de Almeida Pereira}

Tese apresentada ao Departamento de Letras Clássicas e Vernáculas da Faculdade de Filosofia, Letras e Ciências Humanas da Universidade de São Paulo como requisito parcial para obtenção do grau de Doutor em Letras - Estudos Comparados de Literaturas de Língua Portuguesa.

Orientador: Prof. Dr. Mário César Lugarinho 
Autorizo a reprodução e divulgação total ou parcial deste trabalho, por qualquer meio convencional ou eletrônico, para fins de estudo e pesquisa, desde que citada a fonte.

Catalogação na Publicação

Serviço de Biblioteca e Documentação

Faculdade de Filosofia, Letras e Ciências Humanas da Universidade de São Paulo

SILVA, Daviane Moreira e.

No ritmo da lapassiada: leituras do projeto crítico-poético de Edimilson de Almeida Pereira / DAVIANE MOREIRA E SILVA; orientador Mário César Lugarinho. - São Paulo, 2014.

$178 \mathrm{f}$.

Tese de doutorado - Faculdade de Filosofia, Letras e Ciências Humanas da Universidade de São Paulo.

Departamento de Letras Clássicas e Vernáculas. Área de concentração: Estudos Comparados de Literaturas de Língua Portuguesa.

1. Poesia. 2. Crítica Literária. 3. Edimilson de Almeida Pereira. I. , , orient. II. Título. 
NOME: SILVA, Daviane Moreira e. No ritmo da lapassiada: leituras do projeto crítico-poético de Edimilson de Almeida Pereira. Tese apresentada ao Departamento de Letras Clássicas e Vernáculas da Faculdade de Filosofia, Letras e Ciências Humanas da Universidade de São Paulo como requisito parcial para obtenção do grau de Doutor em Letras Estudos Comparados de Literaturas de Língua Portuguesa.

Aprovada em:

Banca examinadora

Prof.Dr. Instituição

Julgamento Assinatura

Prof.Dr. Instituição

Julgamento Assinatura

Prof.Dr. Instituição

Julgamento Assinatura

Prof.Dr. Instituição

Julgamento Assinatura

Prof.Dr. Instituição

Julgamento Assinatura 
Para Maria, Isaac e David, que sempre abrem a porta. 


\section{AGRADECIMENTOS}

Ao Prof. Dr. Mário César Lugarinho, que aceitou a orientação deste trabalho sem me conhecer e que de orientador generoso passou a colega que me ajuda a projetar os caminhos.

À Profa. Dra. Maria José Somerlate Barbosa, que me carinhosamente me recebeu na The University of Iowa, oferecendo acesso ao rico acervo construído em vinte anos de leitura da poesia de Edimilson Pereira.

Ao Prof. Dr. Emerson Inácio pela supervisão durante o PAE e pelas conversas de antes.

To my dear friends at the U.S., Stefan Shöberlein, Byron Williams and Pat Ryan: I thank you for make my life so easier - and warmer.

Ao meu núcleo hard uspiano: Victor Palomo, Sandra Salavodro, Arnaldo Sobrinho, Bruno César, Fátima Fernandes, Márcio Vidal, Sinei Sales e Luana Barossi. Muito obrigada pelos cafés, noites de estudos e por todas as conversas (e veneno) mas, principalmente, por terem se tornado parte da minha vida fora da universidade.

À Rackel Machado, Nani de Bem, Gustavo Antunes, Caroline Brandão Hauaji, Maíra do Valle, Filipe Malkavian e Demetrius Coutinho, que nos últimos quatro anos me acolheram e acarinharam.

À Maria das Graças, David e Isaac, que respeitam as minhas maluquices e apoiam as minhas andanças.

À Coordenação de Aperfeiçoamento de Pessoal de Nível Superior, pela concessão da bolsa de doutorado. 
A margem me propicia os meios Edimilson de Almeida Pereira, "Dedicatória" 


\section{RESUMO}

SILVA, Daviane Moreira e. No Ritmo da Lapassiada: escolhas críticopoéticas na obra de Edimilson de Almeida Pereira. 2014. 150f. Tese (doutorado). Estudos Comparados de Literaturas de Língua Portuguesa. Departamento de Letras Clássicas e Vernáculas da Faculdade de Filosofia, Letras e Ciências Humanas da Universidade de São Paulo, São Paulo, 1995.

RESUMO: O objetivo desta pesquisa é apontar algumas das escolhas críticas e poéticas que são observadas na obra de Edimilson de Almeida Pereira, através das quais é possível investigar diálogos entre manifestações da cultura afrodescendente.

PALAVRAS-CHAVE: Poesia; Crítica; Edimilson de Almeida Pereira. 


\begin{abstract}
SILVA, Daviane Moreira e. No Ritmo da Lapassiada: escolhas críticopoéticas na obra de Edimilson de Almeida Pereira. 2014. 150f. Tese (doutorado). Estudos Comparados de Literaturas de Língua Portuguesa. Departamento de Letras Clássicas e Vernáculas da Faculdade de Filosofia, Letras e Ciências Humanas da Universidade de São Paulo, São Paulo, 1995.
\end{abstract}

The objective of this research is to point out some of the critical and poetic choices that are observed at the work of Edimilson de Almeida Pereira, through which it is possible to investigate dialogues among manifestations of African descent culture.

KEYWORDS: Poetry; Criticism; Edimilson de Almeida Pereira. 


\section{SUMÁRIO}

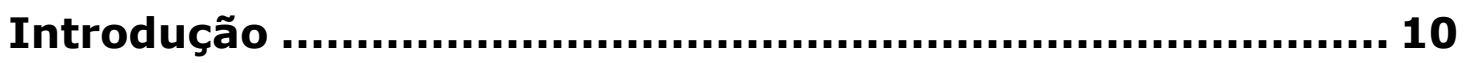

1. "Como os leões, ruja feroz na brecha" ............................ 22

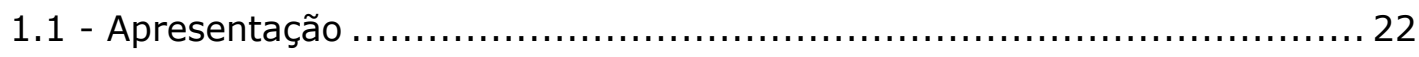

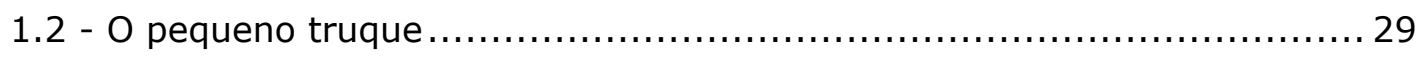

1.3 - Literatura Negra: por que (ainda) não? ................................ 44

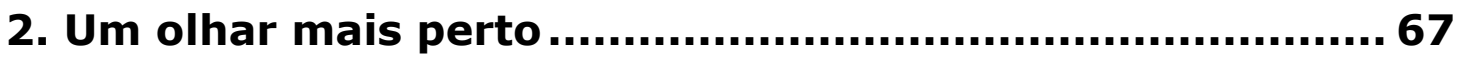

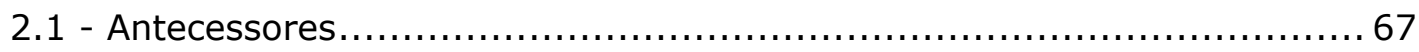

2.1 .2 - Outros Antecessores ................................................ 73

2.2. - Edimilson De Almeida Pereira ....................................... 76

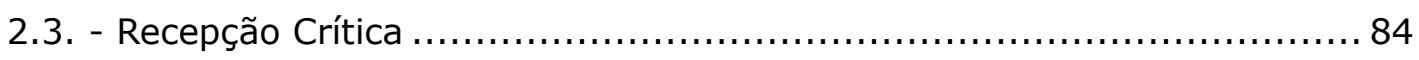

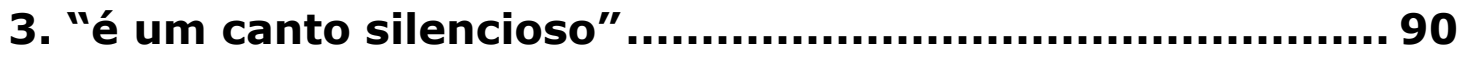

3.1 - Ars Poetica................................................................. 90

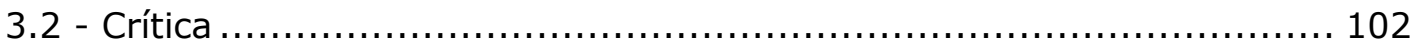

4. "I'M ALWAYS LIKE A TIGER, I'M READY TO JUMP" ........ 129

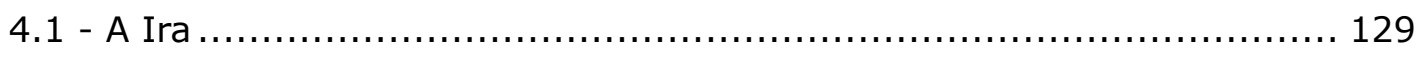

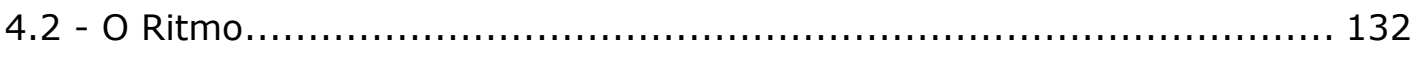

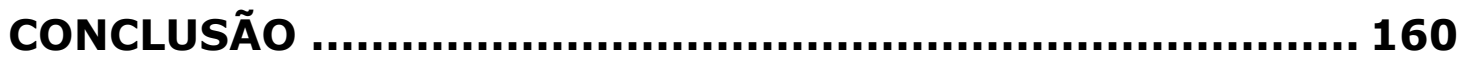

REFERÊNCIAS BIBLIOGRÁFICAS .................................. 163

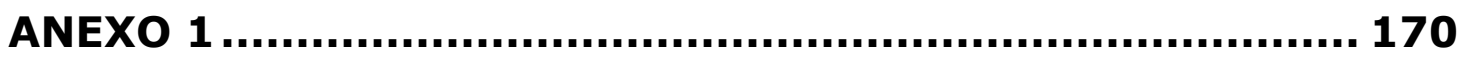

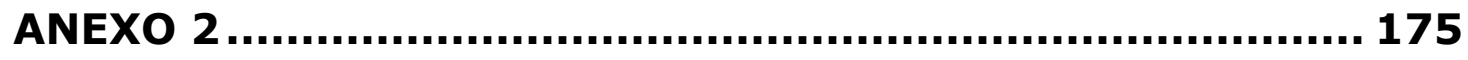

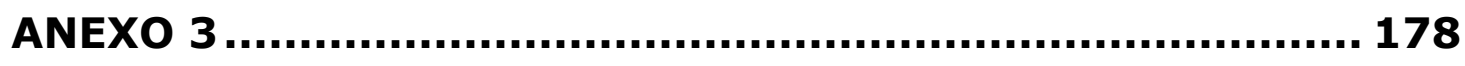




\section{INTRODUÇÃO}

Em entrevista publicada em 1998 na Revista de Literatura Brasileira Brasil/Brazil, Edimilson de Almeida Pereira foi questionado a respeito do título do livro lançado em 1990, Ô Lapassi \& Outros Ritmos de Ouvido. A pergunta se referia à palavra lapassi, e a resposta do poeta é que "[As pessoas da zona rural] raramente terminam a palavra com consoante. Colocam sempre uma vogal no final da palavra. Aí virou a palavra lapassi. Nada mais, nada menos que o 'rapaz' do português padrão." (BARBOSA, 1998, p.105).

Se quiséssemos utilizar a nomenclatura linguística para explicar porque a palavra rapaz acaba se tornando o lapassi da zona rural, poderíamos chamar a variação fonética de metaplasmo, conforme atestam os manuais de estilística para as ocorrências galfo (garfo) e arvre (árvore) (MARTINS, 2008, p.75). No entanto, a explicação do poeta parece mais válida aqui, não pela autoridade do autor, justificando o título da própria obra, mas pela percepção da importância da voz do outro na poética de Edimilson de Almeida Pereira. A preservação do termo como é utilizado por seus falantes, melodiosa por si só, indica como é possível reconhecer quem fala nos poemas (não se faz necessário apontar origem, cor, textura capilar ou poder aquisitivo do eu-lírico para identificá-lo, basta se ater aos vocábulos encontrados nos versos).

Edimilson Pereira lançou, a partir de 2002, a reunião reorganizada de sua obra poética, resultando em quatro volumes nos quais constavam 
tanto poemas antigos quanto inéditos. Após a proposta inicial de pesquisa, dois volumes de poesia foram lançados: o conciso Variaciones de un libro de sirenas (2010c), todo escrito em espanhol como seu predecessor, Signo cimarrón (de 2005) e o longo Homeless, também de 2010, que vem acompanhado por um livreto com (quase) todas as referências que se possa encontrar nas três sessões da obra (para o diálogo com outros textos, o trabalho de pesquisa/investigação cabe ao leitor, começando assim o ato de "mergulhar" na escrita de Edimilson Pereira).

Além dos livros de poesia, o autor lançou quatro volumes de crítica: Depois, o Atlântico (2010) e No berço da noite (2012), ambos organizados com Robert Daibert Junior e compostos por textos de alunos e professores envolvidos com o curso de especialização em História e Cultura Afrobrasileira e Africana da Universidade Federal de Juiz de Fora, onde o poeta/antropólogo/crítico leciona; Malungos na escola (2010), com entrevistas a escritores afro-brasileiros, artigos sobre o currículo da educação no Brasil e comentários sobre o sagrado no cotidiano de alguns grupos; e, finalmente, o longo Um tigre na floresta de signos (2010), com sete sessões para abrigar os textos de poetas e críticos sobre as vozes femininas na Literatura Afro-brasileira, as performances afrodescendentes, as fissuras no que é entendido como afro-brasilidade, entre outros tópicos. Tanto os livros de poesia quanto os de crítica me fizeram repensar o caminho da pesquisa: não seria possível ignorar nem as novas experimentações estéticas empreendidas, nem as reconfigurações analíticas que ficaram mais evidentes nos últimos trabalhos.

Mas o poeta, persona generosa, abriu espaço para que o crítico mostrasse mais explicitamente a que veio, desdobrando a escrita em textos sobre algumas das construções poéticas atualmente feitas no Brasil. Por isso lidei com os livros publicados após o início da pesquisa, incluindo os de crítica, mesmo o autor já tendo produzido uma obra 
bastante extensa. Como o aparecimento dos últimos livros de literatura e os questionamentos sobre os parâmetros do que se entende como poesia no Brasil fizeram-se tão fortemente presentes, foi difícil deixá-los de lado, talvez por aparecerem atando os trabalhos do poeta, do antropólogo e do crítico, como se deixassem mais claro um projeto maior que os abarca todos: as representações e elaborações possíveis através da palavra, que se estendem para a contribuição no estabelecimento de um referencial crítico-teórico sobre a cultura e literatura negras no Brasil, em diálogo com outras áreas da diáspora negra.

À primeira vista, a instrução para se atentar às palavras durante a leitura de poemas parece redundante: como não observar a escolha vocabular quando se está empenhado na análise de um texto poético? Prestar atenção ao léxico do autor costuma ser uma das primeiras orientações aos que se aventuram ao estudo de um poeta. No entanto, o que quero apontar aqui é a forte presença de marcas de oralidade que, em um contexto gramatical normativo, seriam considerados inadequados ou indesejados.

A escrita de Edimilson Pereira abrange o discurso poético, a crítica literária, as histórias infantis e os textos acadêmicos sobre antropologia; tal fertilidade poderia causar uma leitura demasiadamente generalizada das obras. Por esta razão, escolhi me ater à análise das escolhas poéticas feitas por Pereira utilizando a produção do crítico/pesquisador como suporte para este exercício, mas sem a obrigatoriedade de me ater somente a eles. $\mathrm{O}$ projeto inicial consistia em uma leitura voltada para as questões poéticas que surgem nos poemas de Edimilson, com a combinação entre elementos da cultura popular brasileira e da estética ocidental resultando numa elaborada diç̧ão artística. Com o aprofundamento das leituras dos poemas, o interesse pelas utilizações do ritmo, bem como a importância da música dentro da construção foram se 
destacando e sugerindo outros caminhos

Partindo da pergunta de George Steiner, "Que dimensão de homem tal obra propõe?" (1988, p.26), e da epígrafe drummondiana que abre Ô lapassi, "Como vive o homem,/ se é certo que vive?" (PEREIRA, 2002, p.18), li a obra de Edimilson de Almeida Pereira como um questionamento que constantemente se alarga, se multiplica como um caleidoscópio: o ser humano é representado como aquele que vivência o sagrado, que se desloca em errância, que gera frutos, palavras, que por vezes the vê negado o direito de ser gente, mas não desiste nem do canto nem da dança, mesmo quando deixam de ser fonte prazerosa e viram estratégias para permanecer.

Concentrei uma parte do trabalho em demonstrar a contribuição de Edimilson de Almeida Pereira ao pensamento crítico sobre a Literatura Brasileira, seja refletindo acerca da constituição do sistema literário, seja produzindo poesia com uma voz diferenciada que incorpora a musicalidade da diáspora. Realizei um mapeamento dos antecessores escolhidos pelo autor, como se aproxima ou se afasta de alguns nomes representativos das letras nacionais, assim como elege para interlocutores alguns artistas da palavra que nem sempre são reconhecidos como tais, além da posição crítica de Edimilson de Almeida Pereira diante da atual análise das poéticas afro-brasileiras; como sua própria obra poética é lida também é um dos aspectos contemplados.

Como cabe neste momento apontar para a estrutura que se pretende seguir na escrita da tese, proponho a seguinte organização após as últimas investidas crítico-poéticas do poeta/crítico/antropólogo estudado. O primeiro capítulo da tese, "Como os leões, ruja feroz na brecha", é uma contextualização do cenário literário no qual Pereira se insere, principalmente pensando no que é entendido como Literatura Negra e/ou Afrodescendente no Brasil. Foi considerado, para esta parte, a 
configuração do cânone literário afrodescendente no Brasil, debate no qual se insere desde a terminologia a ser empregada até o reconhecimento ou não-reconhecimento de uma produção afro-brasileira. Pereira se insere, aqui, como produtor de textos críticos sobre o tema - embora surja também como poeta quando tem sua obra analisada dentro desse contexto

No segundo capítulo, "Multiplicado na unidade", apresento uma aproximação com Cruz e Sousa, refletindo também no diálogo que empreende com outros poetas, como os caribenhos Aimé Césaire e Édouard Glissant. Esta leitura aponta para a relação com a diáspora negra nas Américas, o que amplia o campo canônico de sua poesia, não circunscrita nem à produção afrodescendente, nem à Literatura Brasileira. Para a apresentação de Edimilson de Almeida Pereira, tanto como poeta quanto como pesquisador de literatura, três aspectos foram considerados: 1) a identificação dos antecessores poéticos escolhidos pelo autor, abordagem que se desdobra principalmente na leitura conjunta com a obra de Cruz e Sousa, mas engloba ainda os caminhos que, percorridos poeticamente, relacionam a poesia de Pereira com a produção artística originária da Diáspora Negra na América Latina e no Brasil em particular; 2) a apresentação de Edimilson de Almeida Pereira através de sua vinculação inicial a grupos artísticos de Juiz de Fora e pela escolha de algumas temáticas poéticas recorrentes em seu trabalho; 3 ) revisão geral da recepção crítica da obra de Pereira, observando quais categorias são utilizadas nas leituras de seus poemas e nas tentativas de analisá-lo no contexto da Literatura Brasileira.

Embora os versos de Edimilson de Almeida permeiem todo o texto, o terceiro capítulo, "É um canto silencioso", é dedicado a uma leitura mais atenta de alguns metapoemas através dos quais é possível encontrar as diretrizes para o entendimento da obra aqui tratada, bem como na análise 
dos aspectos estilísticos; neste mesmo capítulo observo como os escritos do crítico de literatura se relacionam com seu trabalho poético, desenvolvendo a discussão apontada pela faceta do pesquisador a respeito do embate entre as duas visões essencialistas sobre a experiência estética que desde sempre rondam a produção afrodescendente: de um lado a poesia como texto criativo sem espaço para conflitos históricos ou indagações de ordem social; do outro, a ação política desvinculada da experimentação estética (PEREIRA, 2010, p.23). Nesse momento se insere o questionamento dos parâmetros utilizados para a análise poética, que nem sempre conseguem abarcar a produção oral fora dos preceitos estabelecidos como válidos, pautados no texto escrito. Aqui o crítico abre espaço para o antropólogo que testemunhou a vivência do sagrado e as elaborações poéticas dos devotos e cantopoetas praticantes do Candombe.

Devido à extensão da obra, o recorte temático pareceu mais apropriado do que uma leitura cronológica dos poemas. Alguns temas aparecem mais frequentemente, como a construção da identidade do sujeito, muito presente em Zeosório Blues e em "Caderno de retorno" (In: As Coisas Arcas), ou a exploração do espaço, como nos poemas-cidades de $O$ velho cose e macera; entretanto, resolvi me deter nas temáticas da Ira e do Ritmo.

Após o mapeamento feito sobre os metapoemas, exploro no quarto capítulo, "I'm always like a tiger, I'm ready to jump", duas das temáticas dentre as que mais frequentemente aparecem na obra poética: a Ira (como motriz de ações) e o Ritmo (no qual se inserem as canções, as danças e seus desdobramentos); opto por um destaque maior em relação à temática musical na poesia de Pereira por ser um aspecto menos explorado em sua obra e uma das formas de circulação de saber e sobrevivência cultural.

A primeira temática, a "Ira", é entendida não como raiva pura e 
simples, mas como a reação a uma violência que, quando transmutada, serve de combustível para a criação, como explicado em "Santa Efigênia", sobre a construção do convento da santa (vale lembrar que Santa Efigênia é protetora contra incêndios): "Não será de adobe/ nem de pedra./ Vamos fazê-lo/ com nossas iras./ Depois de levantado/ não pega incêndio." (PEREIRA, 2003, p.153-154). Em segundo lugar o Ritmo, o modo escolhido para a realização do projeto estético, advertência lida no poema "Preceito": "Nada aqui se faz sem ritmo" (PEREIRA, 202, p.127).

Os títulos dos capítulos merecem uma explicação. Para nomear os capítulos da dissertação de mestrado ${ }^{1}$, escolhi versos dos poemas de Edimilson de Almeida Pereira que julguei mais condizentes com a proposta daquele trabalho. No caso desta tese, as trocas e aproximações sugeridas pela abertura que os textos de Pereira propõem formam um aspecto que julgo importante de ser destacado. A inserção de várias matrizes culturais no tecido poético, apontando para os modos de vivenciar o mundo e transformá-lo, seja no âmbito estético da poesia, seja na experiência do sagrado dos Arturos foi, muitas vezes, a minha chave para adentrar aos poemas, portanto, resolvi privilegiá-la. O Capítulo 1 foi nomeado com um dos versos do poema "Arte" de Cruz e Sousa, "E como os leões, ruja feroz na brecha" (CRUZ E SOUSA, 1995, p.386). O segundo capítulo, que pretende apresentar Pereira, foi o único nomeado com um verso do próprio: "multiplicado na unidade" é parte de "Passeios - C/ Ricardo Aleixo). "É um canto silencioso" é o trecho de um pedido de "abrição" de porta: na Folia de Reis existem cantos específicos quando o mestre pede que os moradores abram a porta para recebê-los; neste caso, não apenas a porta é aberta, mas também as luzes, antes apagadas, são acesas. E

\footnotetext{
V. SILVA, Daviane Moreira e. "Cahier, Caderno: um diálogo possível". Dissertação de Mestrado. Universidade Federal de Juiz de Fora, 2009. Uma versão resumida do terceiro capítulo da dissertação "Cahier, Caderno, um diálogo possível", foi publicada na Revista Crioula n.06, 2009, com o título "Césaire-Pereira, uma leitura Martinica-Brasil".
} 
finalmente, "I'm always like a tiger, I'm ready to jump", título do Capítulo 3, é um trecho da letra de "Down in the dumps", escrita por Leola Wilson e Wesley Wilson e gravada por Bessie Smith, em 1933 (SCHULLER, 1975, p.29).

Edimilson de Almeida nasceu em Juiz de Fora em 1963, no antigo bairro Meggiolário, hoje Nossa Senhora Aparecida, "na margem direita do rio Paraibuna" (MARQUES, 2004, p.61). Se destaco a localização do bairro em relação ao rio que corta a cidade é para mostrar que essa cisão engloba outra: é na zona Leste do município mineiro que se localizavam os bairros de grande parte dos trabalhadores de fábricas, casas de família e do comércio do centro da cidade.

Em depoimento concedido a Fred Spada sobre a história lírica do lugar onde nasceu, Edimilson de Almeida Pereira comenta que, até a entrada no curso de Letras da Universidade Federal de Juiz de Fora, a "vida se restringia à experiência de bairro, de periferia" (SPADA, 2012). Conseguimos vislumbrar essa atmosfera da vida de bairro nos primeiros poemas de Zeosório blues, com as festas, o futebol nos campinhos, as conversas entre vizinhos, a reprodução dos nomes de companheiros.

A entrada na universidade fez com que ingressasse, em 1983, no folheto Abre Alas e na revista d'lira, que faziam parte do cenário de agitação cultural da cidade, englobando não somente escritores e poetas, mas fotógrafos, artistas plásticos, atores e músicos, que se desdobravam na confecção quase artesanal do panfleto. O que costuma ser ressaltado sobre este período pelos outros poetas que fizeram parte do Abre Alas é a sensação de liberdade - dada a abertura política que o país começava a alcançar - e o debate dos próprios textos com os colegas. Leio nos depoimentos do autor o modo como o desejo por uma reconfiguração do cenário político se conjugava com as experimentações estéticas com as quais iam tomando contato: "a década a qual nos referimos nos 
surpreendeu com a ruptura e a fragmentação de valores, mas, em contrapartida, o reconhecimento da força da palavra se configurou como uma atitude de resistência à desmobilização social e à mera repetição do cânone literário" (PEREIRA, 2007, 186).

Quando o grupo se dissolveu, as especificidades se mostraram melhor - no caso de Pereira, a relação entre pesquisa antropológica e trabalho poético se tornou mais íntima e se mantém ainda hoje, como se faz notar no recentemente publicado Homeless, de 2010, no qual assume a tarefa de "não deixar nunca que a experiência poética, que a experiência estética se afaste também das relações históricas, das relações sociais, das grandes necessidades que a mim muitas vezes desesperam" (SPADA, 2012).

Em artigo de 2011 para a revista Scripta, Maria José Somerlate Barbosa ressalta a ligação existente entre aspectos biográficos e poéticos no trabalho de Pereira como, por exemplo, a economia vocabular poética como reflexo da carência financeira durante a infância (BARBOSA, 2011, p.235).

Além de poeta premiado ("Hors concours" do Prêmio Alberto da Costa e Silva, da União Brasileira de Escritores em 2004; 10 lugar no Concurso Sílvio Romero da FUNARTE/CNFCP e, 2002; Prêmio Marc Ferrez da FUNARTE em 1994, por exemplo), Edimilson Pereira é também antropólogo e professor titular da Faculdade de Letras da Universidade Federal de Juiz de Fora, com graduação em Letras Vernáculas pela mesma instituição, doutorado em Comunicação e Cultura pela Universidade Federal do Rio de Janeiro e pós-doutorado em Literatura Comparada pela Universidade de Zurique.

A produção de Pereira iniciou-se em 1985 com o primeiro livro de poemas, Dormundo, e já conta com mais de vinte títulos, entre eles Árvore dos Arturos e outros poemas (1988), Águas de contendas (1998) e 
Homeless (2010), para citar alguns, fora as parcerias com Ricardo Aleixo (A roda do mundo, 1996), Prisca Agustoni (Traduzioni/Traduções, 1999) Fernando Fiorese e Iacyr Freitas (Dançar o nome, 2000). Publicou obras infanto-juvenis como O menino de caracóis na cabeça (2001), Os reizinhos de Congo (2004) e a Coleção Bilbeli, de quatorze volumes, com Prisca Agustoni (2001-2003).

$\mathrm{Na}$ área de antropologia cultural vale ressaltar as publicações relacionadas ao projeto Minas $\&$ Mineiros, como Os tambores estão frios: herança cultural e sincretismo religioso no ritual de Candombe (2005), Negras raízes mineiras: os Arturos (1988). Organizou, sobre crítica literária, Um tigre na floresta de signos, de 2010.

Apontei apenas alguns títulos publicados por Pereira, com o intuito de demonstrar por onde suas publicações transitam. Um elencamento minucioso da bibliografia do autor pode ser encontrado no final do livro Recitação da passagem: a obra poética de Edimilson de Almeida Pereira, de Maria José Somerlate Barbosa, que conta ainda com um levantamento de textos sobre Pereira, como entrevistas, artigos e resenhas.

Além do já referido Recitação da passagem, que analisa a obra de Pereira destacando a presença de Exu e da tradição africana, algumas das intertextualidades e aspectos metalinguísticos, destaco outras leituras sobre a produção de Edimilson Pereira. Dentre as entrevistas, "Conversa com Edimilson de Almeida Pereira", publicada em 2004 por Fabrício Marques e "An Interview with Edimilson de Almeida Pereira", conduzida por Steven White (1996) são importantes pois, através delas, percebemos a reflexão do poeta sobre poesia e sobre outras questões que aparecem em sua obra, como as representações dos afro-brasileiros.

Dos artigos publicados com leituras sobre a obra de Pereira aponto "Reconversões", de Laura Padilha, que propõe um diálogo entre a poética de Edimilson Pereira e a de Ruy Duarte de Carvalho; o trabalho de Steven 
White, "A reinvenção de um passado sagrado na poesia afro-brasileira contemporânea", com leitura da temática religiosa em poetas afrobrasileiros; e os artigos de Prisca Agustoni, "Os sete selados na poética de Edimilson de Almeida Pereira" e Jussara Santos "Palavra poética em transe/trânsito: manifestações pelos sete buracos da minha cabeça". Além destes trabalhos, os prefácios aos livros de poesia também auxiliam na leitura da obra de Pereira, como Rita Chaves prefaciando As coisas arcas, Iacyr Freitas em "Lugares luminares", Antonio Risério em "E a roda do mundo gira, camará".

Durante o doutoramento na Universidade de São Paulo, as disciplinas cursadas me auxiliaram a formular as reflexões que aparecem nesta tese. Os cursos acompanhados foram, com o Prof. Dr. Renato Seixas, "Comunicação, Cultura e Narrativas do Cotidiano: a Identidade Cultural da América Latina Narrada por Si Mesma", realizado no Curso Interunidades: Integração da América Latina; "Semiótica: Teoria e Aplicação na Canção Brasileira", com o Prof. Dr. Luiz Tatit; "Faces da Poesia Brasileira a partir dos Anos 60", ministrado pela Profa. Dra. Viviana Bosi; "O Texto Poético em Língua Portuguesa", com o Prof. Dr. Emerson Inácio e "Ficção e Utopia: Literaturas Africanas de Língua Portuguesa", com a Profa. Dra. Rejane Vecchia. As discussões propostas pelas disciplinas me ajudaram a pensar não apenas em questões de poética ou sobre o cenário literário brasileiro, mas também a refletir sobre a produção artística no cenário latino-americano e dentro da diáspora negra.

Mas não só as disciplinas foram importantes durante este período: pude participar como revisora e editora da Revista Crioula, o que me ajudou a aprimorar minha leitura crítica; fiz parte do Programa de Aperfeiçoamento de Ensino (PAE), e a possibilidade de acompanhar a organização e execução de uma matéria de graduação complementou minha formação. 
No ano de 2013-2014 fui contemplada com uma bolsa do Programa de Doutorado Sanduíche no Exterior (PDSE/CAPES), que me permitiu trabalhar com a Profa. Dra. Maria José Somerlate Barbosa na The University of Iowa, tendo acesso aos arquivos da professora sobre o trabalho de Edimilson Pereira e contando ainda com sua inestimável atenção ao me receber e discutir comigo os caminhos que fui traçando para a realização desta tese. 


\section{1. "COMO OS LEÕES, RUJA FEROZ NA BRECHA"}

\section{1 - Apresentação}

A escolha do poema "Linguae" para a abertura do primeiro capítulo tem como finalidade demonstrar algumas características da poesia de Pereira que serão melhor exploradas no decorrer deste capítulo e cujo mapeamento pode ser encontrado na Tabela Temática, Anexo 2. Embora este trabalho não pretenda explorar minuciosamente os temas poéticos mais frequentes na poesia de Pereira, mas sim demonstrar as escolhas feitas por ele no âmbito da estética e da crítica, julguei válido ao menos apresentá-los. A diáspora africana, as religiões afrodescendentes, a música dos cantos de trabalho e do blues, o ser humano reificado, a condição à margem do escravo, a exploração dos cenários de circulação dos sujeitos serão retomados posteriormente.

Para iniciar esta introdução parto do seguinte poema:

\author{
LINGUAE \\ o mundo parece \\ outra figura \\ se aceitamos \\ o verbo sem contrário \\ mas se 0 \\ vivido dispara \\ o míssil \\ das perguntas? \\ cabemos \\ no idioma a que não \\ se ajusta
}

[1] 
o país de húmus?

esse idioma

percorre os artelhos

do que

falamos?

: eu memo

é cariocanga

(i circle

the nameless

body)

: eu memo

é capicovite

(glasses are shining

i know
nothing
catch

nothing)

: eu memo

[7]

é cadandumba

serena

(but it is silence

offered up

the ring)

la pierre de notre

origine

s'aniquile

mais

je suis un autre

[9]

avec

ma parfaite

hallucination

a pronunciar

uma nova

espessura [11]

$\begin{array}{ll}\text { àtòrì } & \text { àtòrì } \\ \text { bá } & \text { organiz } \\ \text { mi } & \text { e } \\ \text { to } & \mathrm{a}\end{array}$




$\begin{array}{ll}\text { iyè } & \text { minha } \\ \text { tèmi } & \text { própria } \\ \text { fún } & \text { memór } \\ \text { mi } & \text { ia }\end{array}$

et avec une seule possibilité

: render o medo pois

\begin{tabular}{lll} 
os & \multicolumn{1}{c}{ isìnkú } & [14] \\
fantasmas & òrun & \\
nunca & kì \\
comem & í je & \\
obì & obì & \\
torrado & súnsun & \\
no & n' \\
fogo & íná & \\
: en la lengua & [15] \\
florece & \\
u atrocidad & \\
punto & \\
pucer del cuerpo & \\
ha fiera &
\end{tabular}

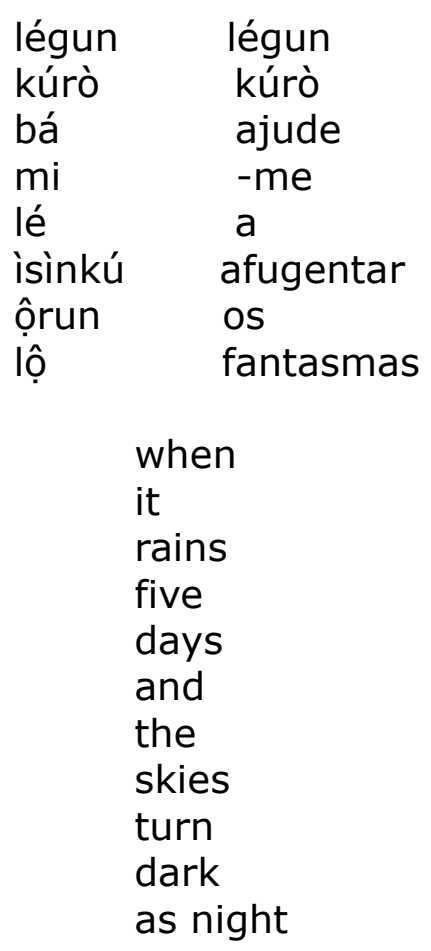


(não) atinamos

[19]

em que

registro

trafega a nave

: la chose la plus claire

[20]

en este huracán

are the spaces between

the words

o que me impede

de ser

apenas extensão

da máquina

et me laisse comme

les travaillers

que negocian

la tempestad

$$
\begin{aligned}
& \text { ombrera } \\
& \text { tutimba } \\
& \text { ô calunga } \\
& \text { ô tomara } \\
& \text { ô tavira }
\end{aligned}
$$

: a máquina

devorada não

[24]

se extingue (espreita

da ferrugem)

o país de uns

$\&$ outros

desde o convés

se enerva

desde a linguagem

- diria,

quem está

em silêncio

[23]

(PEREIRA, 2010, p.116-121)

"Linguae" é o quinto poema de uma série de seis ("Cartografia I", 
"Manhã", "Colisão", "Navio", "Linguae", "Cartografia II") intitulada "Homeless", presente em "Passagem do meio", segundo trecho de Homeless, livro de 2010 de Edimilson Pereira. A série de poemas descreve desde antes da saída dos homens escravizados da África, seguindo com a preparação para o embarque, as transformações que ocorreram dentro do navio durante a travessia, até uma visão contemporânea do processo de escravização. Devido à extensão do poema, indiquei o número das estrofes entre colchetes, para facilitar a leitura.

O poema é composto por vinte e seis estrofes, com número irregular de versos e sílabas poéticas. A princípio, duas coisas chamam a atenção na estrutura do texto: a presença de outras línguas que não o português (além do título em latim, temos inglês, francês, espanhol e vocábulos do grupo linguístico banto) e a distribuição gráfica das sílabas poéticas. As línguas se misturam no texto, com as palavras banto dividindo espaço com o inglês, como nas estrofes 5, 6 e 7, francês e português na estrofe 13, francês e espanhol na estrofe de número 22. À presença destas línguas acrescenta-se o latim do título, "Linguae", com o substantivo feminino declinado no plural.

A presença de outras línguas no texto literário não é novidade no trabalho de Pereira: em Rebojo, de 1995, já é possível encontrar palavras em francês e kimbundu, mas esse multilinguismo poético se intensifica em "Caderno de retorno", de 2010, concentra-se na língua espanhola em Signo cimarrón e Variaciones de un libro de sirenas e junta francês, espanhol, inglês, italiano e vocábulos banto em Homeless. A novidade neste último volume de poesias é, além da presença do italiano e do inglês, o modo como as línguas aparecem. Agora uma frase começada em francês pode terminar em espanhol ou português ("et me laisse comme/ les travaillers/ que negocian/ la tempestad") e ao lado do trecho com palavras em banto aparece a versão em português, como nas estrofes 12 , 
14 e 17 - não se trata necessariamente de tradução direta. As línguas não mais dividem apenas o mesmo poema, mas o mesmo verso: estão amalgamadas.

Enquanto a distribuição das sílabas poéticas nos versos mais curtos, como nas estrofes 12 e 13 parece relacionar diretamente cada palavra banto a uma de língua portuguesa, a distribuição das palavras na estrofe 18 pode ser lida de outra forma. Os versos "when/ it/ rains/ five/ days/ and/ the/ skies/ turn/ dark/ as night" formam a primeira estrofe de "Backwater blues", como aparece na "Porta escrita", o libreto de referências que acompanha Homeless (PEREIRA, 2010, p.07). O que não aparece no encarte é o contexto de composição da música, mostrado por David Evans em "Bessie Smith's 'BackWater Blues': the story behind the song": embora seja geralmente associada à enchente advinda da cheia do rio Mississipi em 1927, a canção, gravada em 17 de fevereiro, dois meses antes do ocorrido, refere-se, na verdade, à cheia que afligiu o rio Cumberland em Nashville, no estado do Tennessee, no Natal de 1926 (EVANS, 2006, p.97). A enchente do Mississipi deixou milhares de mortos, centenas de milhares desabrigados, mais de quarenta mil construções destruídas e lama o bastante para impedir a plantação daquele ano. Estima-se que mais de noventa por cento dos atingidos fossem negros (EVANS, 2006, p.97).

Várias expressões artísticas foram feitas sobre a catástrofe, mas a canção de Bessie Smith é a mais associada ao ocorrido. Quando o principal aterro do rio Mississipi rompeu e a enchente ganhou força, em meados de abril, o disco com "Backwater blues" já estava nas lojas, visto que fora lançado em março de 1927. Vem daí a associação frequente entre a canção de Smith que já circulava na época e o desastre (EVANS, 2006, p.99).

A distribuição dos versos escolhida por Pereira parece mimetizar o 
canto de Smith: na gravação de 1927, acompanhada pelo pianista James P. Johnson, a cantora faz com que as palavras desta primeira estrofe da canção deslizem em seu canto, o que Pereira talvez tenha tentado reproduzir ao colocar cada palavra em um verso. Segundo a explicação de Ted Buehrer:

Note a forma pela qual ela [Bessie Smith] frequentemente desliza para dentro e para fora das notas. Só na primeira linha ela desce em "five" e em "skies", e desliza totalmente em "night". A letra é toda preenchida com notas melancólicas. Note também que, em contraste com a execução ritmicamente precisa de Johnson, o fraseado de Smith é mais relaxado: ela frequentemente canta um tantinho atrasada, um pouco atrás da batida². (BUEHRER, 2006, p.13. Tradução nossa).

No poema de Pereira, o céu escurecendo se transforma não para anunciar a chuva causadora de enchentes como na canção de Smith, mas para indicar a dureza do tempo vindouro de sofrimento em outras terras: a catástrofe aqui será mais longa e penosa.

Assim como o multilinguismo poético, a referência a Bessie Smith não é novidade na obra de Pereira, como atestam as mensagens entre a cantora de blues e Janis Joplin em "De Janis a Bessie" e "De Bessie a Janis" (PEREIRA, 2002, p.97 e p.113), que analisaremos no Capítulo 3.

Os versos ": eu memo/ é cariocanga", ": eu memo/ é capicovite" e "eu memo/ é candandumba/ serena", que no poema de Pereira se distribuem por três estrofes, são os versos do vissungo $\mathrm{XX}$, coletado por Aires da Mata Machado Filho em 1928:

\section{Eu memo é capicovite}

\footnotetext{
2 É possível ouvir a gravação de Bessie Smith e James P. Johnson com os comentários de Behrer em "Listening Guide to Backwater Blues by Bessie Smith". Disponível em <https://www.youtube.com/watch?v=mRTHHkeQ8sE>. Acessado em 28 de abril de 2014.
} 
eu memo é cariocanga

eu memo é candandumba serena.

(MACHADO FILHO, 1985, p.80)

Os cantos recolhidos por Machado Filho foram registrados na região de São João da Chapada, município de Diamantina, Minas Gerais. Os vissungos são cantos encontrados em Minas Gerais e eram entoados pelos escravos durante o trabalho na lavoura, no garimpo e também em brincadeiras e nos velórios. O vissungo XX é descrito como "o cantador gabando suas qualidades" (MACHADO FILHO, 1985, p.80). Nas estrofes 5, 6 e 7, o vissungo XX se mistura aos trechos do poema "Duelo" (PEREIRA, 2003, p.72), traduzido para o inglês por John Keene. A menção a "àtòrí" e "légun kúrò", nas estrofes 12 e 17, se refere a plantas utilizadas nos rituais da Umbanda e do Candomblé.

"Linguae" demonstra as negociações que ocorreram (e ainda ocorrem) devido ao processo da escravização no período colonial e a subsequente dispersão dos africanos pelas Américas. Vemos as trocas linguísticas ocorridas no "útero às avessas" do navio negreiro (PEREIRA, 2010, p.114), que se estendem ao garimpo em Minas Gerais, à música no sul dos Estados Unidos, ao francês caribenho, aos candombeiros do Uruguai.

\section{2 - 0 pequeno truque}

No livro A República Mundial das Letras a autora, Pascale Casanova, parte do conto The figure in the carpet, de Henry James, para defender a 
mudança de perspectiva da crítica literária ao analisar uma obra. No conto de James o narrador, um jovem crítico, é encarregado de escrever um artigo sobre um livro do escritor Vereker. Ao conhecer o escritor e este the revelar a existência em sua obra de "um pequeno truque", "um plano sofisticado", o narrador interpela Vereker para tentar descobrir o verdadeiro assunto de sua obra, ao que o autor indica dois princípios contrários às representações comuns da arte literária: por um lado, existe de fato um objeto a se descobrir em cada obra, e esta é a tarefa legítima da crítica, que não enxerga o óbvio ("Não faço outra coisa senão gritar minha intenção na cara aparvalhada da crítica" JAMES, 1993, p.152) e, por outro lado, esse "segredo" não é da ordem do indizível, ou de uma essência superior e transcendente que impõe um silêncio estático. Após várias investidas para que Vereker revele a mensagem da obra, o autor terminar por explicar a configuração de seu projeto literário: tal como um tapete persa que se constitui de vários motivos para formar o desenho do plano original, cada obra do escritor é um motivo no arranjo do desenho de sua produção. É preciso ter todas as partes para enxergar o motivo completo (CASANOVA, 2002, p.16).

Em oposição a uma noção de insularidade que impede que as obras literárias sejam vistas em conjunto para que assim se observe as semelhanças e diferenças que existem entre elas, Casanova propõe que a leitura das obras seja feita na "totalidade do espaço literário mundial", já que cada obra só encontraria sua significação quando contextualizada com o restante do universo literário. A autora afirma que "As obras literárias só se manifestariam em sua singularidade a partir da totalidade da estrutura que permitiu seu surgimento. Cada livro escrito no mundo e declarado literário seria uma parte ínfima da imensa "combinação" de toda a literatura mundial." (CASANOVA, 2002, p.17). Tal como na reflexão sobre linguagem proposta por Ferdinad de Saussure, em que tudo se ergue 
sobre relações, sejam elas de oposição ou associação entre signos, em que a língua é vista como um sistema cujas partes funcionam em solidariedade sincrônica (SAUSSURE, 1995, p.96), o argumento de Casanova é de que não há significação em isolamento.

No cenário da República das Letras que a crítica francesa mapeia, o conceito de valor é retomado a partir das observações de Goethe e Valéry ao descreverem os intercâmbios culturais com um vocabulário emprestado da economia e do comércio, com Valéry afirmando que

há um valor chamado 'espírito', como há um valor petróleo, trigo ou ouro. Disse valor, porque há apreciação, julgamento de importância e também discussão sobre o preço que se está disposto a pagar por esse valor, o espírito. Pode-se fazer um investimento com esse valor; pode-se rastreá-lo, como dizem os homens da Bolsa; pode-se observar suas flutuações em alguma cotação, inscrita em todas as páginas dos jornais, como ela compete aqui e ali com outros valores, pois há valores concorrentes (...). Todos esses valores que sobem e descem constituem o grande mercado dos negócios humanos. (CASANOVA, 2002, p.27)

Os indícios do poder do capital literário nacional são encontrados também em Valéry, que aponta, por exemplo, os textos declarados nacionais, as obras convertidas em história nacional, a antiguidade da literatura, o número de textos considerados "clássicos" frente a outras literaturas nacionais. $O$ contrário desse prestígio literário também pode ser mensurado, e a autora se apoia em Antonio Candido para demonstrar que as altas taxas de analfabetismo, os parcos meios de difusão literária, a pouca especialização dos escritores montam o palco da fraqueza de capital literário nacional. (CASANOVA, 2002, p.30).

Retomo o texto de Casanova pela lembrança de Henry James e a figura do tapete e pela percepção do léxico de autores clássicos da economia, como Adam Smith e David Ricardo, nas falas dos autores de 
literatura dos séculos XVIII e XIX. O aprofundamento na discussão sobre o cânone literário não é o principal tópico desta tese, mesmo assim, julgo relevante apontar o que alguns textos desse debate apontam pois, mesmo não sendo novidade, ajudam a compor o cenário de construção do cânone literário negro ou afrodescendente que ocorre atualmente na Literatura Brasileira, no qual Edimilson de Almeida Pereira se insere, ora como crítico, ora como poeta.

Os debates sobre o cânone literário que ganharam fôlego nas universidades brasileiras nas últimas duas décadas, tendo em vista, principalmente, a publicação de $O$ cânone ocidental, do norte-americano Harold Bloom, gerando inúmeras respostas. Lançado no Brasil em 1995, O cânone ocidental ganhou espaço tanto em cursos acadêmicos de literatura quanto em revistas semanais ${ }^{3}$.

A primeira definição de Bloom é que canônicos são os autores obrigatórios em nossa cultura. Essa obrigatoriedade vem da estranheza nunca inteiramente assimilada ou que nos assimila de modo a nos fazer cegos para seu caráter peculiar: este é o sinal de originalidade que dá status canônico a uma obra (BLOOM, 1995, p.12-15). Ao apontar a origem religiosa do termo, indica que a escolha é feita "entre textos que lutam uns com os outros pela sobrevivência". A única forma de uma obra adentrar na eleição de textos canônicos é através da força poética, constituída pelo domínio da linguagem figurativa, originalidade, conhecimento e dicção exuberante. $O$ teste que confirmaria a canonicidade de um texto é a releitura da obra (BLOOM, 1995, p.27-36)

"Leio, logo existo". Entrevista a Flávio Moura. Revista Veja. Edição 1685, 31/01/2001. Disponível em: http://veja.abril.com.br/310101/entrevista.html. Só Shakespeare salva". Entrevista a Luís Antônio Giron. Disponível em http://revistaepoca.globo.com/Revista/Epoca/0,,EDR718086060,00.html. Acessado em 27/05/2014. "'Acho que a paz é uma impossibilidade'"'. Entrevista a Paulo Polzonoff. Revista Continente Multicultural, n.65. Publicado em 01/05/2006. Disponível em http://www.revistacontinente.com.br/index.php/component/content/article/2197.html. Acesso em 27/04/2014. 
Para o autor, o debate atual sobre o cânone divide-se entre dois pólos que trabalham com premissas falaciosas - de um lado os "Direitistas do Cânone", cujo argumento principal é que o cânone preserva e transmite valores morais que Bloom considera inexistentes; do outro lado, a "Escola do Ressentimento", composta basicamente por pesquisadores dos estudos culturais, que tentariam derrubar o cânone para promoção de programas de transformação social. Nos dois extremos, o problema maior seria a fuga do estético:

Nossas legiões que desertaram representam uma corrente
em nossas tradições que sempre esteve em fuga ao estético:
moralismo platônico e ciência social aristotélica. O ataque à
poesia ou a exila por ser destrutiva do bem-estar social ou
lhe concede tolerância se ela assumir o trabalho de catarse
social sob as bandeiras do novo multiculturalismo. Por baixo
da superfície de marxismo, feminismo e neo-historicismo
acadêmicos, continua a correr a antiga polêmica do
platonismo e a igualmente arcaica medicina social
aristotélica. (BLOOM, 1995, p.26)

A argumentação de Bloom é bastante virulenta e, embora defenda ferozmente os parâmetros de qualidade que julga essenciais, escolhendo termos pejorativos para se referir aos críticos literários com ideias contrárias às suas, nem tudo produzido por ele é descartável, como é o caso da teorização sobre influência literária e da retórica da imortalidade.

Segundo o autor, para que haja obra canônica é necessário o processo aflitivo da influência literária, e o prêmio para quem sobrevive ao conflito entre o gênio passado e a aspiração presente é a inclusão no cânone e subsequente sobrevivência literária (BLOOM, 1995, p.17). No processo da influência, os escritores capazes de transformar seus antecessores em seres compósitos tornam-se escritores fortes.

Para a explicação da retórica da imortalidade, Bloom parte da definição de ansiedade feita por Freud, as expectativas ansiosas (Angst 
vor etwas). Segundo o autor, as obras adquirem ansiedades humanas, e uma delas em especial, o medo da morte, transmuta-se, no âmbito literário, na tentativa de canonização por parte da obra (BLOOM, 1995, p.26). A listagem oferecida das obras canônicas é também uma lista de sobreviventes:

\begin{abstract}
A questão é a mortalidade ou imortalidade das obras literárias. Onde se tornaram canônicas, elas sobreviveram a uma imensa luta nas relações sociais, mas essas relações muito pouco têm a ver com luta de classes. Os valores estéticos emanam da luta entre textos: no leitor, na linguagem, na sala de aula, nas discussões dentro de uma sociedade. [...] O valor estético surge da memória, e, portanto (como viu Nietzsche), da dor, da dor de abrir mão de prazeres mais fáceis em favor de outros muito mais difíceis. [...] Também os cânones são ansiedades realizadas, não esteios unificados de moralidade, ocidentais ou orientais. (BLOOM, 1995, p.44-5).
\end{abstract}

No caso de Bloom, é interessante notar o local do qual o discurso é pronunciado: enquanto professor da Universidade de Yale, uma das mais prestigiadas dos Estados Unidos, a fala de Bloom é tão apaixonada quanto privilegiada. Se o valor estético emana da luta entre os textos que ocorre nos debates em sala de aula e na sociedade, conforme destacado na citação anterior, os lugares com maior capital literário, para usar a expressão de Casanova, serão aqueles com maior força e poder para apontar a legitimidade de determinadas obras. Harold Bloom adota um discurso acusatório ao comentar as correntes críticas contemporâneas não por realmente estar ameaçado, mas por não conseguir dialogar com as novas leituras das obras literárias. O que imprime valor às obras e as elege para a posteridade está nos textos, nos escritores, nos lugares de legitimação e, principalmente no gosto pessoal do próprio Bloom.

Retomando ao debate no Brasil, Leyla Perrone-Moisés, no livro Altas 
literaturas, é bastante cuidadosa no que se refere à explicitação e detalhamento dos conceitos utilizados na elaboração do cânone dos escritores-críticos: a ensaísta faz um apanhado dos valores estéticos utilizados pela crítica desde os românticos ("novidade e originalidade"); traça ainda um levantamento da utilização dos termos "cânone", "clássico", das propostas de paideuma. Após o trabalho centrado nos escritores modernos, o último capítulo do livro se volta para a pouca popularidade da leitura nos tempos atuais ("O desafeto progressivo pela leitura é um fenômeno internacionalmente reconhecido"PERRONE-Moisés, 1998, p.178), para a exemplificação do que a autora indica como oscilantes definições da pós-modernidade, até comentar o cenário do ensino de literatura no Brasil. Ao se referir à fama de inutilidade das ciências humanas e da adequação dos cursos de Letras a uma grade curricular que privilegie o ensino de línguas, a autora indica os professores como os principais responsáveis pelo sufocamento dos estudos literários. Para Perrone-Moisés, a escolha dos textos a serem lidos vem sendo feita baseado em critérios de "raça", "gênero" e "classe" (1998, p.191). A crítica não é aos estudos culturais como um todo, mas a uma superficialidade que rondaria a área:

Não me ocorre, como a ninguém ocorreria, a ideia de negar o valor de estudos realmente culturais. Praticados sobre objetos precisos, e com sólido conhecimento das diversas disciplinas que eles requerem, os estudos culturais são de uma inegável utilidade, além de ser uma necessidade premente no mundo atual. O que me parece danoso é a prática de um ecletismo superficial transformado em "superdisciplina", que eclipsa as disciplinas específicas e as exclui pouco a pouco dos programas. E a consequente produção de discursos "culturais" generalizantes e fortemente ideológicos, carentes da necessária fundamentação histórica, antropológica, sociológica ou filosófica. (PERRONE-MOISÉS, 1998, p.192) 
As características atribuídas ao cânone - universalidade, hierarquia e durabilidade -, deveriam ser, segundo a estudiosa, as mesmas utilizadas para avaliar obras em que se intentasse acrescentar ao cânone. Ao ler o texto de Bloom, Perrone-Moisés aponta o caráter apocalíptico e de diatribe de algumas afirmações de Bloom (PERRONE-MOISÉS, 1998, p.199), mas concorda com ele no que se refere à defesa dos critérios estéticos para os estudos literários em lugar de critérios ideológicos, visto que indica que o estético não é necessariamente reacionário. A posição reticente da autora em relação aos estudos culturais, cujo destaque no Brasil considera como adesão irrefletida à polarização norte-americana entre culturalistas e tradicionalistas (mas não se refere à adesão entusiasmada aos estruturalistas franceses), aparece também em outros críticos como Terry Eagleton: na introdução de Depois da teoria, de 2003, o crítico inglês reconhece o valor dos estudos culturais ao abrir espaço para as leituras de obras pós-coloniais, por exemplo, mas ironiza ao imaginar os objetos das teses de doutoramento como as implicações políticas do piercing no umbigo ou a hermenêutica de se passar um dia na cama. O que quero apontar é que não apenas críticos conservadores receberam os estudos culturais com reservas diante de uma produção crítica que por vezes parecia deixar a literatura de fora.

Mas é importante ressaltar, também, a existência de um debate que reflete sobre os estudos culturais - originados na Inglaterra, em fins dos anos 1950, por Raymond Williams e Richard Hoggart, responsáveis pela fundação do Center for Contemporary Cultural Sudies. Tal debate não se contenta em repetir afirmações importadas ou da Inglaterra ou dos Estados Unidos, mas problematizam os estudos culturais no contexto latino-americano, como feito por Alberto Moreiras em $A$ exaustão da diferença. Em "A indisciplina dos Estudos Culturais", Beatriz Resende faz um levantamento dos debates inicias em torno dos estudos culturais no 
Brasil, partindo dos encontros da Associação Brasileira de Literatura Comparada desde 1996, com a presença de Homi K. Bhabha, até o momento da publicação do artigo, em 2002. O que a autora aponta é o trajeto dos estudos em face a outras áreas, dentro e fora da área de Letras e sem ignorar o contexto latino-americano, o que vai de encontro ao pensamento irrefletido que Perrone-Moisés enxerga na área. Resende retoma a importância do feminismo e da multiplicidade identitária para os estudos:

sobretudo, o que me interessa nos Estudo Culturais é a politização - no sentido grandioso que a palavra deve ter da investigação intelectual proposta. É na pluralidade cultural, no reconhecimento das diversas subjetividades, nas múltiplas identidades e na certeza de que, por exemplo, existem na literatura brasileira muitas literaturas brasileiras, que está a possibilidade de se reconhecer o complexo, o diferente, o outro. (RESENDE, 2002, p.49)

No artigo de 2006, "Literatura para todos", Perrone-Moisés desenvolve a ideia esboçada no final de Altas literaturas ao apontar as mudanças no ensino de literatura no Brasil, nas séries fundamentais e um maior empenho, por parte dos professores universitários, em se queixarem sobre o parco repertório de leitura dos alunos que chegam nos cursos superiores do que preparar estes alunos para lecionarem nos ensinos básico e fundamental (PERRONE-MOISÉS, 2006, p.18). A autora aponta a importância de se ensinar obras canônicas nas escolas, visto que os alunos socialmente privilegiados acabam por entrar em contato com elas no âmbito familiar ou nas escolas particulares.

Um contraponto aos textos de Bloom e Perrone-Moisés é "Cânone literário e valor estético: notas sobre um debate de nosso tempo", de Idelber Avelar. A proposta do texto de Avelar é apresentar pautas para a discussão sobre valor estético que estejam baseadas na descontinuidade 
entre os conceitos de valor, cânone e estética, ressaltando a impossibilidade do conceito de valor estético se apresentar de modo imanente à obra. A estratégia para apresentar essa descontinuidade começa com o princípio de que mesmo as correntes críticas com maior viés cientificista se utilizam de parâmetros valorativos e que tanto a crítica e quanto a teoria literárias sempre trazem implícitas uma posição sobre valor.

Sobre o caráter dicotômico que os escritos sobre cânone literário assumem, Avelar argumenta que tanto as ideias de valor estético quanto de cânone literário devem ser repensadas, e que a formulação do debate defendida por duas posições antagônicas é por si mesma problemática: de um lado, os defensores do cânone, que defendem a manutenção do mesmo; do outro, os culturalistas, interessados em sua relativização ou abolição (AVELAR, 2009, p.114).

O texto oferece um levantamento da conceituação de valor no decorrer dos movimentos do século $X X$, tais como o New Criticism, 0 Formalismo Russo e o estruturalismo francês, com o intuito de demonstrar que, mesmo implicitamente, o conceito de valor sempre esteve presente. Avelar apontando a variação de posicionamento sobre o tema nas análises das correntes críticas do século $X X$ e em análises contemporâneas, e notadamente o caso de Wayne Booth, no qual a utilização do reductio ad absurdum como prática comparativa é gritante (contrastando Rei Lear à revista Hustler, por exemplo). As falácias apocalípticas encontradas em alguns dos textos citados pelo autor parecem baseadas em princípios transcendentais para analisar a literatura: "formação do caráter, mergulho na alma humana, renovação da linguagem, progresso do espírito, defesa do legado ocidental, emancipação do proletariado" (AVELAR, 2009).

Um dos tópicos do artigo, "Crítica estética e pânico ocidentalista", é 
dedicado ao comentário do livro de Harold Bloom, O cânone Ocidental, e à obra de Leyla Perrone-Moisés, Altas literaturas. Nessa parte a escrita de Avelar se torna mais inflamada e aponta que tanto Bloom quanto Perrone, enquanto guardiões de um valor socialmente precário em seu fundamento, se sentem ameaçados, e por isso é menor "sua capacidade de entrar em genuíno debate com a força emergente que aponta o caráter contingente desse valor." (AVELAR, 2009, p.124).

Para Avelar, a questão principal à qual a teoria literária deveria se ater, no embate entre culturalistas e esteticistas, é a da descontinuidade entre as noções distintas de cânone, valor e estético, o que permitiria uma identificação melhor sobre o que atribui valor estético no contexto da Literatura Brasileira, por exemplo. A proposta de Avelar de uma genealogia do conceito de valor para ajudar na concretização desta empreitada é interessante, e seu artigo se atém à proposição de demonstrar a indissociação que tão frequentemente ocorre entre os termos na crítica e teoria literárias. A percepção de que o conceito de valor estético sempre foi utilizado como justificativa para a eleição de determinadas obras, mas não claramente esmiuçado, é bastante válida.

Conforme ressalta o autor, talvez a discussão esteja sendo reduzida ao ponto de não se perceber no que ela pode contribuir: a construção da história do valor literário no Brasil. É apontado no texto que o conceito de valor abre um rico horizonte para a crítica literária, mas que se torna obscurecido se o reduzirmos ao problema de quais autores farão parte do panteão de leituras obrigatórias; essa redução une esteticistas e culturalistas, "ocidentalistas" e "particularistas". Perdido nesse debate fica o fato óbvio, mas pouco analisado, de que o conceito de valor não se reduz a suas consequências para o cânone (AVELAR, 2009).

Antes que a discussão tomasse corpo com os textos mencionados, um artigo de René Jara e Jenaro Talens, "Comparatismo y semiótica de la 
cultura" (JARA \& TALENS, 1998, p.5) ressaltava claramente um aspecto sobre o cânone literário que não deve ser esquecido. Ao retomarem o dito de que "la historia la hacen los pueblos, pero la escriben los señores" ["a história é feita pelos povos, mas escrita pelos senhores], Jara e Talens apontam a frase como aplicável a qualquer discurso que queira historicizar, ou seja, narrar o percurso de uma atividade humana. A escolha das obras literárias com as quais a História e a crítica trabalham não estaria vinculada, portanto, às noções como valor estético ou à necessidade de preservação de grandes obras da humanidade, mas ao intuito de se construir um referencial para justificar o modo de viver e pensar o mundo pela sociedade atual.

A institucionalização dos estudos literários foi articulada de modo a refletir os valores do pensamento ilustrado burguês, além de constituída com parâmetros que se pretendiam científicos e se articulavam em três conceitos. O primeiro deles, o valor da tradição literária como modelo, era originário do caráter normativo da retórica clássica e da busca de uma essencialidade no fenômeno literário; em seguida a noção de nacionalidade, variante artística da história política de uma comunidade nacional no momento em que começam a surgir movimentos de independência, e que combinaria a língua dominante nesta comunidade e a ideia de nação. O terceiro critério é a premissa de que a história tem um sujeito central, de caráter individual, assim os textos de literatura são analisados e periodicizados tendo como referência a figura do autor, proprietário do sentido do texto (JARA Y TALENS, 1988, p.5).

Um dos aspectos centrais para a argumentação de Jara e Talens é a percepção do processo histórico como sendo apresentado de modo naturalizado, sem implicações histórico-ideológicas. Quando se percebe, por exemplo, que as mudanças de terminologias entre as "gerações" ou "escolas literárias" não implicam a mudança do paradigma, visto que o 
conceito de autoria individualizada continua funcionando como ponto de articulação, percebe-se também o papel ideológico da história da literatura. Outro fator apontado no texto são as bases econômicas e profissionais do cânone - ao estabelecimento deste parâmetro segue-se o surgimento de mecanismos para sua manutenção, tais como as disciplinas universitárias (JARA Y TALENS, 1988, p.7). Mais do que um modo de preservar e classificar a história, o cânone é um instrumento para escrever a história literária.

Os autores apontam três fenômenos ocorridos nas décadas de 1970 e 1980 que foram importantes para o cenário literário: o primeiro deles, a explosão da literatura de testemunho baseada em experiências de tortura e violação dos direitos humanos, que corrói os limites entre o real e a representação; o segundo, o discurso crítico feminista que desafia os padrões oficiais de validação literária, sempre masculinos. Interessante notar que este fenômeno se move da margem para o centro gravitacional ao atrair outros textos, formando uma tradição alternativa, um "canon alterno". O terceiro acontecimento seria o da fenomenologia do testemunho.

O discurso crítico feminista apontado gerou consequências na configuração do cânone, dessa maneira, a literatura escrita por mulheres obrigou a rearticulação do sistema de valores vigentes. Como os novos textos apresentavam uma visão de mundo distinta da até então reproduzida, o leitor precisou acessar outras chaves semânticas para acessar as mensagens sugeridas. A ficção feminista requer critérios de análise construídos em bases semióticas diferentes e recorre aos relatos de experiência cuja

peculiaridade temática se explica, talvez, pela imediatez com que as mulheres têm experimentado o sentimento de 
impotência. Este, ao ser posto na perspectiva do relato, se converte em mecanismo de compreensão, em encantamento e rejeição de si mesmo. A opção pela loucura, pelo abandono do controle e pela causalidade se converte, paradoxalmente (para a aventura masculina da significação) em tábuas sagradas de uma lei do ser que lhes é negada na racionalidade. (JARA Y TALENS, 1988, p.9. Tradução nossa).

A perspectiva da literatura feminina gerou uma mudança no modo de encarar a literatura, antes inacessível no mundo das essências. No contexto em que a literatura feminina começou a demandar outros parâmetros para a leitura de sua produção, o estruturalismo e o New Criticism haviam cristalizado o fazer literário na autorreferencialidade. O sentido mundano era rechaçado pelo cânone e ao poema era dada uma justificativa tautológica. A poesia assumia o caráter sagrado ao satisfazer a nostalgia humana pela harmonia e identidade das origens. A crítica justificava a tautologia do poema que se justifica em si mesmo e, simultaneamente, conservava seu próprio lugar ao se promover como a única capaz de estabelecer os critérios da doxa (JARA Y TALENS, 1988, p.10).

Além da crítica feminina, o discurso audiovisual, propagado por um meio hegemônico, ajudou no questionamento dos parâmetros canônicos. Deste modo, a tarefa de subversão intelectual é a de reconfigurar o corpus literário com

outra concepção da realidade, com outros valores. Esses valores surgiram predominantemente daquelas vozes que até agora estavam condenadas a articular as sílabas do silêncio, que buscavam um acesso à linguagem, uma participação nas estruturas do poder. [...] Se impõe já, pouco a pouco, com a opacidade mesma do corpo, uma heterodoxia, um registro de valores fundados no respeito do outro, na diferença. [...] A função do crítico e do professor é reconhecer a constituição de uma nova plataforma axiológica que renova as estruturas do sentido e exige estratégias 
semióticas de investigação. (JARA Y TALENS, 1988, p.12. Tradução nossa).

René Jara e Jenaro Talens apresentam, ao final do texto, propostas como a necessária redefinição da História da Literatura, o que implica substituir a "sucessão de centros" por "processos sem centros". Como uma parte da relação dialógica dos diferentes discursos da cultura, o que coloca a História da Literatura em uma dupla relação: com a intertextualidade literária, na qual se percebe o discurso literário como inserido numa rede de outros discursos; com a intertextualidade cultural, com as relações sintagmáticas e paradigmáticas do discurso literário em relação ao discurso da literatura em sua própria língua e com outras línguas, além dos discursos que compõem uma cultura situada num espaço-tempo específico. Como a permanência de uma obra no cânone não implica a qualidade imanente desta obra, mas a continuidade de uma função, a História da Literatura deve ser estudada como o processo de institucionalização social de uma prática discursiva (JARA Y TALENS, 1988, p.15).

Nesta abertura que permite o surgimento de uma crítica voltada para as literaturas que "articulam as sílabas do silêncio", se inserem a literatura feminina e a literatura negra, na qual Edimilson de Almeida Pereira se movimenta em duas frentes. Conscientemente ou não, parte do projeto literário de Edimilson Pereira corresponde à noção de nacionalidade demonstrada por Jara y Talens: o cânone da Literatura Negra brasileira é pensado na obra de Edimilson Pereira, em suas atividades enquanto crítico e enquanto poeta, com os movimentos de ajudar a erigir e explicitar a constituição desta literatura dentro e em diálogo com a Literatura Brasileira, apontando suas especificidades mas longe do isolamento apontado e defendido por alguns. Mas, antes de 
chegar propriamente à atuação de Pereira, vale especificar o que se entende ou se rechaça como Literatura Negra no Brasil.

\section{3 - Literatura Negra: por que (ainda) não?}

Em dezembro de 2011, o poeta Ferreira Gullar, em texto intitulado "Preconceito cultural", fez sua apreciação da utilização do termo literatura negra brasileira como forma de designar a literatura escrita por negros ou mulatos: o poeta considerou a denominação desprovida de pertinência, sem cabimento. Para aquele considerado um dos mais importantes poetas vivos no país, ganhador do Prêmio Jabuti de 2011, Literatura Negra simplesmente não existe, uma vez que os africanos escravizados que aqui chegaram não tinham literatura (entenda-se literatura, nesse caso, como a arte dos textos escritos, exclusivamente). Machado de Assis, Cruz e Sousa e Lima Barreto não poderiam, portanto, ser entendidos como autores representativos de uma literatura afro-brasileira por terem escrito seus trabalhos baseados em paradigmas estéticos europeus.

É preciso ressaltar que não há, no artigo, a negação da contribuição afrodescendente na formação da identidade nacional, mas somos orientados a não tentar separar o que é herança cultural negra ou branca, visto que, de acordo com o autor, somos todos mestiços. O texto de Gullar indica que a contribuição afrodescendente à cultura brasileira é clara e facilmente identificável na música, na dança, no Carnaval. A obra literária, contudo, não entra nessa equação (GULLAR, 2011, s/p).

Um dos argumentos do texto é pautado na ideia de que a cor da 
pele do autor não caracteriza sua produção como literatura negra, e Ferreira Gullar exemplifica este ponto principalmente com Cruz e Sousa e Machado de Assis:

Cruz e Souza era negro; Machado de Assis, mulato, mas tanto um quanto outro foram herdeiros de tendências literárias europeias, fazendo delas veículo de seu modo particular de sentir e expressar a vida. Não se pode, portanto, afirmar que faziam "literatura negra" por terem negra ou parda a cor da pele. (GULLAR, 2011, s/d).

Destaco que as aspas que encerram a nomenclatura "literatura negra" estão presentes no texto original: como nesse caso o termo indicado entre aspas não se refere a uma citação, uso de estrangeirismo ou arcaísmo, diálogo ou título de obra, resta a explicação de que o recurso estilístico foi aqui empregado "para realçar ironicamente uma palavra ou expressão" (CUNHA, 1985, pg.644). Não há como negar o esmero linguístico do qual se utilizou Ferreira Gullar para demonstrar seu posicionamento de que, se a expressão "literatura negra" vem sendo utilizada, é melhor que permaneça entre aspas, afinal, não se deve levá-la muito a sério.

A explicação inicial no texto de Ferreira Gullar é sobre a pertinência do termo "escultura negra", no início do século XX, para indicar as obras africanas que inspiraram os artistas plásticos que circulavam e produziam na Europa. Segundo ele, o termo é adequado por se referir não à etnia dos produtores mas sim a uma expressão própria da cultura negra. No caso da literatura, tal tratamento não procede, ao contrário, mostra uma tentativa de cisão, de separar o que é negro e o que é branco quando, na verdade, tudo é brasileiro.

À publicação do texto não tardaram as reações dos mais diversos tipos. Em uma delas, o texto "A empáfia do poeta Gullar", o poeta Cuti 
(Luiz da Silva) ressalta o comentário do poeta sobre o analfabetismo que, para os negros escravizados no Brasil, não era uma questão de opção, mas de lei. Como exemplo para esta afirmativa é possível lembrar, por exemplo, do decreto $1.331 \mathrm{~A}$ de 17 de fevereiro de 1854, conhecido como a reforma de Couto Ferraz. O referido decreto instituía a obrigatoriedade do ensino para crianças maiores de 7 anos e gratuidade no caso das instituições primárias e secundárias da Corte. Mas a lei ainda tinha mais uma função: proibir o ensino para portadores de doenças contagiosas e para escravos (SILVA \& ARAÚJO, 2005, p.68). Há uma indicação clara de que escravos alfabetizados, assim como a propagação de doenças, eram nocivos à sociedade e precisavam ser evitados.

Cuti prossegue seu texto exemplificando outros autores negros, como Aimé Césaire e Léopold Senghor, também herdeiros de tradição literária europeia, que utilizaram a língua francesa e os recursos estéticos apreendidos na poesia para criar uma expressão própria de suas culturas, afrodescendentes de língua francesa na Martinica e no Senegal. O que Cuti aponta é a dificuldade de Ferreira Gullar enxergar as representações simbólicas que aparecem na produção literária afrodescendente, que não se baseiam unicamente na fenotipia do autor ou de um imaginado leitor negro (SILVA, 2011, s/p).

Em outra resposta a "Preconceito cultural", Francisco Maciel questiona o encerramento da literatura como produção exclusivamente escrita, utilizando, para tal, o exemplo de Mestre Didi, escritor, artista plástico e alapini - posição mais alta no Culto dos Egunguns. O argumento de Maciel é justificado pela citação a Mestre Didi na coleção Literatura e Afrodescendência no Brasil: "Com a sua literatura, Mestre Didi contou casos, narrou a história da cultura africana na Bahia e registrou antigos Itans, que são contos que fazem parte do patrimônio sagrado da tradição nagô. Baseadas na oralidade, tais narrativas ganham a chancela 
do texto impresso, sendo publicado no Brasil e no exterior" (ASSIS, 2011, p.474). Ao argumento de Ferreira Gullar de que "é tolice ou má-fé" associar o reconhecimento dos escritores negros brasileiros à formação de um público leitor negro, Maciel lembra o estudo de Regina Dalcastagnè que demonstrou, entre outras coisas, a sufocante homogeneidade racial dos autores nacionais publicados pelas principais editoras do país. Independente do período analisado pela pesquisadora (1990-2004 e 1965-1979), mais de noventa por cento dos autores eram brancos.

O texto de Ferreira Gullar chamou tanta atenção, dentre outros fatores, pelo alcance que têm as palavras do poeta e crítico de arte ao escrever sobre literatura numa mídia de grande circulação. Além do Jabuti de 2011, o poeta recebeu o prêmio Camões de 2010, o mais importante prêmio literário de Língua Portuguesa que, instituído há mais de vinte anos por um acordo cultural entre os governos português e brasileiro, visa "consagrar anualmente um autor de língua portuguesa que, pelo valor intrínseco da sua obra, tenha contribuído para o enriquecimento do património literário e cultural da língua comum". (Direção-Geral do Livro, dos Arquivos e das Bibliotecas, $s / d, s / p)$. Uma rua em São Luís foi nomeada em sua homenagem ${ }^{4}$, recebeu o título de doutor honoris causa pela Universidade Federal do Rio de Janeiro ${ }^{5}$, consta nos manuais de Literatura Brasileira como autor do indiscutivelmente impactante "Poema sujo".

Ferreira Gullar é um poeta famoso (considerando a extensão da fama que um poeta pode ter no Brasil). Mais do que conhecido, é também um nome estabelecido e respeitado, quanto a isso não há dúvidas: mesmo

\footnotetext{
4 Rua Ferreira Gullar - Anjo da Guarda. In: Google Maps. Disponível em:https://www.google.com/maps/place/Rua+Ferreira+Gullar+-+Anjo+da+Guarda/@-2.5454914,44.3310543,17z/data=!3m1!4b1!4m2!3m1!1s0x7f688c8cb591551:0x295a04becc4c302b. Acesso: 23 de abril de 2014.

5 "O dia do poeta". Disponível em: http://www.ufrj.br/mostraNoticia.php?noticia=10732_O-diado-poeta.html>. Acesso em 23 de abril de 2014.
} 
uma matéria com o título "Ferreira Gullar impostor" se utiliza do reconhecimento do lugar de Ferreira Gullar na Literatura Brasileira como artifício para chamar a atenção do leitor que, atraído pela referência ao poeta, se depara com uma matéria sobre suas cópias de quadros famosos e colagens artísticas ${ }^{6}$.

Não é à toa que uma declaração destas apareça justo agora: com o crescimento dos estudos sobre a Literatura Afrodescendente no Brasil, as políticas afirmativas como a Lei 10.639/03, que instituiu a obrigatoriedade de aulas de História e Literatura Negra no ensino básico, os estudos afrobrasileiros receberam outro destaque, com presença exigida em bancos escolares e editais de cultura.

Mas, como sempre acontece, quem se encontra já numa posição estabelecida tende a se sentir injustiçado quando o direito do outro é expandido ou, nas palavras de Cuti, "a literatura, sendo a menina dos olhos da cultura, deve ser defendida da invasão dos negros." (SILVA, 2011 s/p). Talvez identificar a existência de uma produção literária negra, dentro da literatura brasileira, seja demais para algumas pessoas; é como se o reconhecimento da continuidade negro-literatura fosse uma ofensa e houvesse a necessidade de manter a literatura como reserva de mercado privilegiada.

Alguns meses antes, a Editora da UFMG lançara uma coleção em quatro volumes, organizada por Eduardo Assis, que contou com a participação de mais de sessenta pesquisadores envolvidos no trabalho de mapear e estudar a literatura produzida por afrodescendentes no Brasil desde o período colonial. Constituída de ensaios, estudos de obra e fontes de consulta, a coleção Literatura e Afrodescendência no Brasil: antologia crítica, parece mais do que palpável e coerente para aprovar a pertinência

\footnotetext{
6 "Ferreira Gullar impostor". Disponível em: http://revistapiaui.estadao.com.br/edicao4/esquina/ferreira-gullar-impostor. Acesso: 23 de abril de 2014.
} 
da utilização do termo Literatura Afro-Brasileira.

Sobre a questão da Literatura Afro-brasileira, vou me ater aos seguintes aspectos: a nomenclatura empregada; as principais características do que é entendido como Literatura Afro-brasileira e a aceitação ou rejeição desta produção na crítica literária brasileira.

No artigo de jornal que escreveu em fins de 1908, um mês após a morte de Machado de Assis, José Veríssimo usou a frase "Mulato, foi de fato um grego da melhor época" para se referir ao escritor. Após a publicação do texto, Veríssimo foi alertado em carta por Joaquim Nabuco de que a palavra mulato era pejorativa e que Machado era um branco, mesmo com algum "sangue estranho", que the prejudicava as características caucásicas (OLIVEIRA, 1974, p.70).

Passados mais de cem anos do episódio, talvez seja desnecessário falar da releitura dos textos de Machado de Assis com estudos centrados nos elementos de afrodescendência presentes em sua obra, ou na "capoeria verbal", descrita por Eduardo de Assis Duarte como a dissimulação do jogo de capoeira que Machado de Assis reproduz em seus textos (DUARTE, s/d, p.03). Porém, o estabelecimento de Machado de Assis no cânone literário nacional talvez não tivesse ocorrido se o autor houvesse optado por outra estratégia; caso tivesse explorado com maior frequência e de modo mais explícito a cultura afrodescente em seus textos, teria Machado conseguido adesão para fundar a Academia Brasileira de Letras, receber homenagens póstumas de outros escritores, ocupar hoje o mesmo lugar na Literatura Brasileira?

Luiz Ruffato, no prefácio ao livro Questão de pele, demonstra, pelo exemplo de Lima Barreto, qual seria a situação de Machado de Assis caso fosse mais enfático em seus escritos: "é com Lima Barreto que chegamos ao ápice da representação do negro na literatura brasileira. Comprometido com a causa afrodescendente, desde seus primeiros escritos assumiu sua 
condição de mestiço - e pagou caro por isso." (RUFFATO, 2009, p.14).

Um dos trabalhos iniciais sobre Literatura Negra no Brasil é de Luiza Lobo, cujos artigos sobre o tema podem ser encontrados da terceira parte de Crítica sem juízo. No livro, Lobo apresenta um levantamento de grupos e autores afrodescendentes então atuantes (década de 1980), como Negrícia, Gens e Quilombhoje, as antologias de Paulo Colina, Axé e de Oswaldo de Camargo, A razão da chama.

A autora ressalta a poesia como a produção negra mais destacada, seja pela maior influência que os autores receberam da música popular, seja pelo espaço deixado quando os poetas se exilaram por conta da ditadura (LOBO, 1003, p.165). Os textos de Luiza Lobo encontrados em Crítica sem juízo são interessantes pelo elencamento de grupos, obras e autores da Literatura Negra cuja fixação é importante para constituir sua história. No entanto, quero destacar algumas questões apontadas pelos textos, como a proposta de definição da literatura afro-brasileira. Segundo Lobo, uma das características da literatura negra é o traço logocêntrico, com ênfase na palavra oral em oposição à escrita com o distanciamento entre significado lógico e sentido pragmático como forma de encontrar um universo simbólico-discursivo próprio (LOBO, 1993, p.171). Outro ponto importante é a diferença entre a produção de autores negros, com postura didatizante e militante, geralmente levando à africanização, em relação às autoras negras, mais inclinadas a uma renovação da linguagem e com menos utilização da noção épica histórica.

Em "O negro de objeto a sujeito", a autora indica a mudança da posição do negro, de temática, portanto objeto, para autor de uma visão do mundo. Embora use frequentemente a expressão "literatura negra", Lobo aponta a necessidade de uma nomenclatura específica: "para arrancar a literatura negra do reduto reducionista da literatura em geral que a trata como tema folclórico, exótico, ou como estereótipo, é preciso 
que ela seja, verdadeiramente, uma literatura afro-brasileira". (LOBO, 1993, p.215). No final do artigo, aponta que, mesmo com essa utilização, o destaca maior ainda é para o aspecto brasileiro da literatura, não para o caráter afrodescendente.

Outro trabalho que estabeleceu características da produção afrodescendente foi a tese de doutoramento de Zilá Bernd, "Vozes negras na literatura brasileira: contraponto com as literaturas de língua francesa no Caribe", defendida em 1987 e publicada como livro, em 1988, no livro Introdução à Literatura Negra; a proposta de Bernd de apontar as características da literatura negra é feita, portanto, em contraponto à literatura caribenha.

Em determinado momento, a obra discute o motivo de textos com a mesma temática terem alcançado destaques nas instâncias legitimadoras enquanto outros permaneceram obscuros. Afora as qualidades estéticas, algumas obras alcançam sucesso em seu lançamento, como O Gaúcho, de José de Alencar, enquanto outras obtêm reconhecimento apenas posteriomente, como Martín Fierro, de José Hernández. A hipótese de Bernd é que as obras nas quais a voz dos vencidos aparece mostrando sua visão da História não são bem recebidas.

A defesa da legitimidade da expressão literatura negra se faz pelo argumento de que negar a nomenclatura é tão nefasto quanto não reconhecer as reivindicações dos autores que podem dela se utilizar. Segundo Bernd, a maior característica da literatura negra são "os procedimentos de (re)novação do mundo circundante", como a crítica que torna possível a descoberta de autores antes considerados irrelevantes.

$O$ ato de nomear é o gesto de tomar posse do que está sendo nomeado: se a renomeação é a principal característica da literatura negra, o marcador estilístico mais expressivo é a enunciação do discurso em primeira pessoa, confirmando a premissa da autora de que nem a cor da 
pele do autor, nem a temática do texto é que definem a literatura negra, mas a prova textual do enunciador que se apresenta como negro (BERND, 1988, p.22).

Para melhor explicitar a importância de uma nomeação específica para a produção afrodescendente, Bernd apoia-se na ideia de reterritorialização apresentada por Gilles Deleuze e Félix Guattari em Mil platôs: capitalismo e esquizofrenia (DELEUZE \& GUATTARI, 1995, p.). A autora defende o fazer poético na literatura negra como um processo para a retomada de territórios culturais que ficaram perdidos para o grupo em questão.

Em trabalhos subsequentes Zilá Bernd prosseguiu com o posicionamento apresentado em 1988 com alguns acréscimos. No artigo de 2010, "Da voz à letra: itinerários da literatura afro-brasileira" algumas ideias do livro de 1988 são prolongadas, sendo expostas também na Apresentação da edição de 2011 da Antologia de Poesia Afro-Brasileira: 150 anos de consciência negra no Brasil. As principais características dessa produção seriam:

a) existência fora da legitimidade conferida pelo campo literário instituído;

b) emergência do eu-enunciador que reinvindica sua identidade negra, ou seja, sua pertença a um imaginário afro-brasileiro que urge se reconstruir no Brasil;

c) construção de uma cosmogonia que remonta ao período anterior às travessias transatlânticas nos navios negreiros, isto é, um restabelecimento de elos culturais com a África;

d) ordenação de uma nova ordem simbólica, fazendo emergir na poesia elementos ligados ao mundo da escravidão como instrumentos de tortura, transformando-os em símbolos de resistência;

e) reversão dos valores e avaliação do outro, na tentativa de tornar positivos elementos que se constituíam, em função da construção de estereótipos, em fatores de exclusão e/ou alienação do negro, como o cabelo pixaim, o formato do nariz, etc. (BERND, 2010, p.30) 
Se ressalto os textos de Bernd é por terem sido frequentemente citados pelos estudiosos posteriores do assunto, como Eduardo de Assis Duarte (2011), Jussara Santos (2002) e Maria Nazareth Soares Fonseca (2002), por exemplo.

Sobre a nomenclatura, dada à produção literária afro-brasileira, no início do século $X X$, o termo literatura negra passou a dividir espaço com as expressões afro-brasileira e afrodescendente. A justificativa é que negro indicaria uma definição da expressão artística pela cor da pele, quando a intenção é justamente mostrar que a literatura ou afro-brasileira ou afrodescendente recebe este nome por ser negro o sujeito da enunciação, não mais visto como objeto.

A novidade no trabalho de Bernd é a diferenciação proposta para as tendências identitárias, divididas entre a tendência ao enraizamento identitário (raiz única), na qual a construção identitária, articulada de modo a unir a comunidade contra práticas discriminatórias, encerra-se nas referências da comunidade negra. E a tendência ao enraizamento dinâmico e relacional, conceito do pensador francês Michel Maffesoli pautado na identidade como abertura para a relação com o outro (BERND, 2011, p.34). Esta ideia apresenta-se também no pensamento de Édouard Glissant.

Retomando a discussão sobre a nomenclatura utilizada para designar a produção literária negra e/ou afrodescendente, faço agora referência ao livro de Cuti (Luiz Silva), Literatura negro-brasileira. Nele, após um apanhando histórico sobre a literatura negra no Brasil, Cuti questiona a utilização do prefixo "afro", que ligaria os autores mais à África do que ao Brasil, deixando-os ainda mais à margem em relação à Literatura Brasileira, da qual a Literatura Negro-Brasileira faz parte. Além disso, afro engloba não negros, como mulatos e brancos que, por não 
carregarem características fenotípicas mais marcantes, não passariam pela experiência de discriminação racial.

As principais vertentes terminológicas apontadas por Cuti são: afrobrasileira, "com iniciativa de estrangeiros e respaldada pelos estudos acadêmicos", literatura negra, preferida pelos estudiosos negros não vinculados ao ambiente acadêmico. Em sua fala sobre a rejeição ao prefixo afro, Cuti parece compartilhar alguns pontos em comum com Ferreira Gullar:

Os negro-africanos que no Brasil chegaram escravizados não trouxeram em sua bagagem nenhum romance, livro de contos ou de poesia que pudessem ter servido de base para a continuidade de uma literatura afro no Brasil. Veio sim, a literatura oral. Entretanto, os textos escritos têm sua gênese fundamental em outros textos escritos, apesar de outras influências secundárias. Quando se transpõe um conto oral para o papel tem-se a exata dimensão de seu deslocamento e inconsistência para a literatura. [...] Quanto ao "sabor" para a leitura, há sempre que lhe faltar o tempero (o som da fala, sua entonação e teatralidade do momento de sua narração, além do público receptivo para ouvi-lo). (CUTI, 2010, p.45)

Cuti aponta a inexistência de uma literatura afro no Brasil por não haver, entre os africanos que para aqui vieram, o objeto livro ou textos literários escritos. Ignora as características da literatura oral afrodescendente como se as reproduções dos ritmos e gestos retomados pela literatura escrita não fossem válidos. Ignora totalmente o trabalho de Ricardo Aleixo cujas performances poéticas quebram com os limites apontados por Cuti.

Luiza Lobo, ao referir-se a uma entrevista concedida no Centro de Estudos Afro-Asiáticos em 1986 por Éle Semog, Arnaldo Xavier, Roseli Nascimento, Miriam Alves e José Jorge, aponta a clara distinção feita pelos entrevistados sobre a segregação imposta exteriormente e o cerco 
formado por eles mesmos:

ou você está a favor da autonomia da cultura negra, mas se coloca de fora das suas discussões intrínsecas, ou você adota uma atitude pseudo-acadêmica, científica e finge que está por dentro: mas aí cai na armadilha do paternalismo. Não tem meio-termo. É preciso ser convidado para romper com o cerco que os negros se criaram para pensar sua identidade. "Mas" - explica Miriam Alves, uma das autoras contemporâneas - "o que nós poetas negros vivemos hoje não é um gueto. Gueto é quando se é segregado pelos outros. Hoje nós vivemos o quilombo; a revolta que nós mesmos provocamos". (LOBO, 1993, p.162)

Minha intenção aqui é demonstrar essa divisão feita pelos autores e estudiosos da Literatura Negra e/ou Afrodescendente como movimento consciente, como consciente é a escolha dos escritores apontados nos ensaios sobre História da Literatura Negra no Brasil. Essa tentativa de estabelecer limites, características, quem pode ou não ser identificado com pertencente a essa faceta da Literatura Brasileira, tudo me parece previsto no percurso de um movimento que tenta se afirmar depois de tantas tentativas de apagamento. O que me parece perigoso é o encerramento, a falta de abertura para o diálogo e a troca na qual alguns autores e estudiosos parecem se apegar, o que Zilá Bernd identifica como "tendência ao enraizamento identitário" (BERND, 2011, p.24).

$\mathrm{O}$ ato de fechar-se às alteridades e exigir sempre uma postura combativa, pautada na explicitação constante do preconceito, desfavorecimento social, parece não deixar espaço para mais nada, principalmente no que se refere à experimentação estética. Cuti continua a discorrer sobre nomenclatura ao referir-se a Wole Soyinka:

Wole Soyinka, escritor nigeriano, teve sua frase de efeito contrária à Negritude e à sua insistente afirmação de ser negro - bastante difundida entre os que pretenderam e 
pretendem, entre outras coisas, dizer aos negros: "Calemse!". A frase foi a seguinte: "Um tigre não fala sobre a sua tigretude, ele salta sobre sua presa para devorá-la". [...] A frase de Soyinka angariou um fã-clube de "tigreiros" em todo lugar por onde a Negritude incomodou e, até hoje, lança-se mão desse "Cala boca, negro!", pronunciado por um genuíno negro-africano. (CUTI, 2010, p.55)

A frase de Soyinka se tornou um marco para discussões sobre produção afrodescendente: durante um congresso de escritores negros, a discussão voltou-se para a Negritude, movimento iniciado por Leopold Senghor e Aimé Césaire e chegou à necessidade dos autores explicitarem suas identidades étnicas. A esta questão Soyinka respondeu que "Um tigre não proclama sua tigritude: ele salta" (JANH, 1968, p.265). Seria incoerente que a frase de Soyinka sugerisse que questões étnicas não pudessem ser ou retratadas ou discutidas em criações artísticas: sua própria obra aponta para isso ao inserir a cultura tradicional da Nigéria face à modernização do país, além do problema do racismo, mas o faz não de forma idealizada - a luta política de Soyinka lhe valeu várias prisões.

O discurso de Cuti, até então bem estruturado no seu detalhamento da literatura negro-brasileira, cai no jogo reducionista de que esta literatura só se faria negra ao se pronunciar continua e explicitamente no texto, com a necessidade do autor declarar sua fenotipia, como se a opacidade da obra literária fosse dispensável em se tratanto da literatura negra: "de que vale a pele escura do autor se seu texto se constitui em uma constante invisibilização do teor simbólico de sua pele e de suas características fenotípicas?" (CUTI, 2010, p.57).

A atuação de Cuti no âmbito da Literatura Negra não é de se ignorar: em entrevista a Charles Rowell publicada na revista Callaloo, ao ser questionado se haveria mesmo necessidade de um movimento, como o Quilombhoje, que destacasse os autores negros em relação aos demais 
na literatura brasileira, considerando a ideia de democracia racial propagada pelo país, Cuti comenta a introjeção do racismo pelos negros e o clareamento de Machado de Assis nas fotografias (ROWELL \& SILVA, 1995, p.902-903). Embora por vezes a fala de Cuti proponha um certo encerramento da Literatura Negra em torno de si mesma, a construção do cânone e da história da literatura afro-brasileira redimensionam o cânone literário brasileiro, mas não com o intuito de implodi-lo, como pensam Bloom e Perrone-Moysés em relação aos estudos culturais e à produção de grupos periféricos, mas para mostrar que outros centros, outras possibilidades são possíveis.

Conforme dito anteriormente, o fechamento não é a opção de todos. Ao considerar a obra de Pereira, convém dar muita atenção ao que não é dito explicitamente. Em entrevista do autor concedida a Steven White e publicada pela revista Callaloo, fica claro que as expectativas em relação à produção do poeta são frustradas se a busca é por uma mensagem que faça sempre referência ao "homem negro", como lemos no trecho destacado:

Quem lê meus poemas pode esperar que a maioria das pessoas que falam neles sejam negros. Isso distingue os meus textos dos de outros poetas que frequentemente usam expressões como "homem negro", "mulher negra" [...]. Até agora, ninguém me encontrou usando expressões que façam referência explícita ao "homem negro" na minha poesia, embora eu ache que muitas pessoas gostariam que eu fizesse isso. Eu escrevo coisas que ouço os negros dizerem". (WHITE, 1996, p.50. Tradução nossa)

O poeta opta por uma escolha dialógica face às "exigências" ou expectativas do que se espera de um autor que incorpora elementos da cultura afro em sua produção. Outra voz que surge contra o encerramento do sujeito dentro de classificações é a de Ricardo Aleixo, parceiro de 
Pereira em $A$ roda do mundo, em entrevista a Fabrício Marques:

A designação "poeta negro" é índice tão só da dificuldade do sistema literário para lidar com "o que não é espelho". Uma coisa é chamar Cruz e Sousa de "poeta negro", "Dante Negro", quando não havia nenhum outro poeta de pele preta por perto. Era preciso, naquele momento, chamar a atenção do sistema literário para o fato de que um dos melhores poetas do período era um descendente de africanos escravizados. Outra é, em pleno século XXI, querer aprisionar um poeta no rótulo "poeta negro", sem que sua obra indique o desejo de ser lido dessa forma. (MARQUES, 2004, p.115)

A leitura associada aos conceitos de Édouard Glissant justifica-se, portanto, pela escolha do diálogo e não por uma raiz única da Literatura Negra e/ou Afrodescendente, conforme condensado pela citação de Wole Soyinka "Un tigre no anuncia su tigritud, salta".

O martinicano Édouard Glissant, retomando o conceito de raiz única apresentado por Guilles Deleuze e Félix Guattarri em Mil platôs, analisa a identidade cultural do Caribe e das Américas para chegar às identidades presentes no processo de crioulização. Embora o conceito inicial seja apresentado pelos autores franceses, Glissant atualiza-o a partir do contexto caribenho. Antes de partir para os conceitos de Glissant que julgo interessantes para ler a obra de Edimilson Pereira, apresento uma contextualização do pensamento de Édouard Glissant e Patrick Chamoiseau.

Enquanto pensadores martinicanos que propuseram outras formas de pensar a questão identitária do homem negro, Glissant e Chamoiseau, em seus trabalhos individuais, partiram da proposta de rizoma de Deleuze e Guattari, combatendo fundamentalismos que se constituíram tendo como pretexto de afirmação das identidades. A crioulidade, alternativa pensada por Chamoiseau, supõe no mesmo espaço o encontro de 
elementos culturais europeus, africanos, asiáticos e caribenhos, e a interação entre eles, o que significa uma abertura em relação à negritude, que considerava fortemente o elemento negro, e não a interação; o contato entre culturas diferentes proporciona o surgimento de uma cultura crioula.

Glissant amplia o conceito de crioulidade atribuindo-lhe mais duas noções: o processo e o dinamismo; as novas culturas, compósitas, vão sendo continuamente construídas, sem que seja possível prever um resultado dessa construção. Posteriormente, em Écrire en pays dominé, Chamoiseau adere às noções propostas por Glissant e opta pelo uso do termo crioulização para explicitar o processo de construção identitária caribenha, no qual a idéia de unidade, raiz única, é impraticável (BERND, 2004, p.103). Essa construção compreende uma abertura ao outro, sem que para isso seja preciso perder-se no outro, subjugar-se ou negar o diálogo, ensimesmando-se numa identidade negra sem a colaboração de outras matrizes culturais. Para referir-se a esse homem em construção permanente, Glissant usa a forma verbal étant (sendo):

Penso que chegamos a um momento da vida das
humanidades em que o ser humano começa a aceitar a idéia
de que ele mesmo está em perpétuo processo. Ele não é ser,
mas sendo e que como todo sendo, muda. Penso que esta é
uma das grandes permutações intelectuais, espirituais e
mentais de nossa época que dá medo a todos nós. Todos
temos medo desta idéia: um dia vamos admitir que não
somos uma entidade absoluta, mas sim um sendo mutável.
Essa noção de consciência e de rapidez fulminante tem como
conseqüência não chegarmos a uma nova estase, a uma
nova fase, digamos, de fixação. (GLISSANT, 2005, p.33)

Além do "sendo mutável" glissantiano, destaco o espaço como importante constiuinte de seus conceitos críticos: a América é um elemento importante no pensamento de Glissant não apenas na forma de 
se ver o mundo na América, ou de se estar no mundo enquanto escritor/ povo americano, mas a própria estrutura física, a geografia do espaço caribenho estão presentes no pensamento glissantiano, como o exemplo que utiliza para abordar as diferenças culturais entre europeus e caribenhos, diferenças semelhantes às suas respectivas naturezas geográficas: assim como a cultura de seus habitantes, o Mar Mediterrâneo concentra, ao passo que o Mar do Caribe abre, difrata.

Marx Hantel, em texto de 2012 intitulado "Errant Notes on a Caribbean Rhizome", destaca a utilização de conceitos de Gilles Deleuze e Félix Guattari no pensamento de Édouard Glissant; o texto de Hantel é o início de um projeto maior sobre as ligações entre Édouard Glissant e Deleuze e Guattari. O trabalho apoia-se apoia em Poétique de la Relation, de 1990, a obra de Glissant que mais se aproxima do pensamento dos autores franceses, principalmente no que se refere ao conceito de rizoma, explorado em Mil Platôs.

Hantel concentra sua argumentação na discussão sobre o "espaço esburacado" que aparece em "Tratado de nomadologia: máquina de guerra", volume 5 de Mil Platôs (DELEUZE \& GUATTARI, 1997, p.8). A justaposição entre os dois pensamentos "enfatiza a materialidade poética de Glissant e a incorporeidade do empirismo radical de Deleuze e Guattari" (HANTEL, 2012). Sobre o papel no Outro no pensamento de Glissant e o rizoma, Hantel comenta que:

Quando Glissant se refere ao pensamento rizomático como uma relação na qual "cada e toda identidade é prolongada através de uma relação com o Outro", torna-se claro que ambos os sentidos de identidade e do Outro mudaram para ele. Primeiro, identidade é uma demarcação particular em questão de fluxo, uma concretização provisória de qualidades extensivas e intensivas. Glissant está particularmente preocupado em como os sujeitos negociam a força assombrada da escravidão e da colonização como 
uma formação de memória que não está sempre materialmente presente. (HANTEL, 2012, s/p. Tradução nossa.)

Glissant aponta o pensamento rizomático por trás da poética da relação em que cada identidade se extende em relação com o Outro, o que se aproxima da filosofia de Deleuze e Guattari ao tratar de um sistema raiz mas se afasta ao se referir a identidade e o Outro. O ponto de Hantel é apontar como o pensamento glissantiano circula a filosofia deleuze-guattariana mesmo optando por uma terminologia diferente; o percurso escolhido para tal comprovação passa por Foucault, escrito por Deleuze, e pela ideia foulcaultiana de heterotopia para chegar aos conceitos de Glissante de errância e opacidade. Quando fala sobre o caosmundo, Glissant retoma na distinção feita por Deleuze e Guattari entre raiz única e rizoma:

No encontro das culturas do mundo, precisamos ter a força imaginária de conceber todas as culturas como agentes de unidade e diversidade libertadoras, ao mesmo tempo. É por isso que reclamo para todos o direito à opacidade. Não necessito mais "compreender" o outro, ou seja, reduzi-lo ao modelo de minha própria transparência, para viver com esse outro ou construir com ele. Nos dias de hoje, o direito à opacidade seria o indício mais evidente da não-barbárie. (GLISSANT, 2005, p.86).

Os dois principais argumentos de Hantel são de que o rizoma é mais produtivo quando pensado pelo "espaço esburacado" que aparece no "Tratado de nomadologia" e de que o rizoma cresce imprevisivelmente no "não-espaço" entre conteúdo e expressão. Para Hantel,

Retrabalhando conceitos deleuzeguattarianos, Glissant fornece um modo de comprometimento com traumas do passado que nem desaprova totalmente o sentido do fato histórico do sofrimento nem identifica completamente com a 
facticidade da memória nem uma inabilidade de mover-se além da realidade daquele sofrimento. O rizomático abraço da erraticidade e da opacidade articula novos modos de subjetivação e coletividade, ambos fundamentados e abertos, escapando da falsa escolha entre a raiz totalizadora e o desenraizamento. (HANTEL, 2012, s/p. Tradução nossa.)

Como observado no ensaio "Negociação e conflito na construção das poéticas brasileiras contemporâneas", de Edimilson de Almeida Pereira:

a Literatura Negra e/ou Afro-brasileira sustenta uma linha pragmática, que circunscreve a pauta de criação, enredando o poeta numa trama na qual ele se vê obrigado a oferecer respostas imediatas às demandas extraliterárias. Nesse caso, a liberdade de experimentação soa como esteticismo alienante, ao invés de se apresentar como recurso para a formulação de novas configurações e interpretações do real. (PEREIRA, 2010, p.31)

O discurso que nega a existência de uma Literatura Afro-brasileira, ou que argumenta que a Literatura Brasileira não precisa de segmentações, como se tudo acolhesse harmoniosamente, com o mesmo destaque para todas as obras, vem sendo questionado no que se refere à escolha do cânone literário brasileiro. Conforme argumenta José Jorge de Carvalho no ensaio "As culturas afro-americanas na Ibero-América: o negociável e o inegociável", de 2003, as expressões simbólicas afroamericanas começaram a se inserir no meio mercadológico através de uma dinâmica que privilegiava o fetiche da restituição dos valores perdidos pelo Ocidente, como a riso, o erotismo, a espontaneidade, a sacralização do cotidiano (CARVALHO, 2003, p.108).

Apresento o texto de Carvalho por ser um dos trabalhos que pensa a cultura afro-americana, partindo de suas idiossincrasias culturais, econômicas, políticas. Um ponto que Carvalho frisa no decorrer do trabalho é a importância de não se assimilar o conteúdo teórico importado 
de grandes potências econômicas de maneira irrefletida.

O autor reflete a partir do cenário dos anos 1990, quando o modelo neoliberal foi amplamente celebrado como o parâmetro a ser seguido, no qual os países periféricos deveriam limitar a intervenção do Estado, abrir a economia, transferir para órgãos privados os projetos sociais e abrir mão dos projetos nacionais. Com estas ações, a globalização traria maiores oportunidades de negócios e intercâmbios simbólicos. O discurso se mostrou falacioso pelo fato dos estados nacionais de maior poder internacional terem permanecido fortes, o que levou à conclusão de que a falência dos países periféricos era devida à perda de autonomia, ao descontrole da dívida externa e ao desequilíbrio econômico e simbólico (CARVALHO, 2003, p.102).

Quando alguns dos países periféricos começaram a transferir a responsabilidade de investimento em projetos culturais do Estado para empresas privadas, a validade de um elemento cultural passou a ser medida através de sua capacidade de se converter em mercadoria, não mais pelo "seu potencial de emancipação, resistência, reinvindicação ou expressão de identidades discriminadas e fragmentadas", o que certamente não leva em conta os desejos dos produtores afro-americanos (CARVALHO, 2003, p.103). No entanto, para que a parceria entre a empresa privada e o artista funcionasse, se fazia necessário que a produção artística fosse esvaziada ideológica e politicamente, gerando no artista a preocupação de adaptar sua arte ao mercado, o que sufocava principalmente as expressões artísticas marginais.

A exemplificação desse esvaziamento é feita quando o autor se refere ao caso do grupo Olodum, cuja proposta inicial de luta contra o racismo e mobilização da comunidade negra de Salvador começou a arrefecer após a projeção internacional do grupo. Quando inserido no circuito de entetenimento internacional, o Olodum e outros blocos afro 
transformaram o protesto em representação estética inofensiva, apresentando-se, no dia 20 de novembro, não nas ruas, mas em clubes fechados para empresários internacionais cujo objetivo era escolher grupos para tours em outros países.

A proposta de Carvalho não é a de julgamento contra a circulação de bens culturais, mas uma crítica ao modelo como as formas culturais afroamericanas são comercializadas em caráter de "canibalismo simbólico", com a promoção das formas culturais afro-americanas para entretenimento, "que toma o mercado como neutro, dessinteressado politicamente ou alheio às transformações simbólicas profundas que provoca". (CARVALHO, 2003, p.113).

Destaco a argumentação de Carvalho antes de introduzir o trabalho de Edimilson Pereira para apontar a relevância do debate crítico se construir considerando fatores não apenas estéticos: 0 jogo mercadológico, por exemplo, não deve ser excluído de um debate sobre literatura afrodescendente, considerando que os signos afro, quando inseridos na circulação de bens de consumo, costumam ser rentáveis sem a marcação política explícita, ou sem tentar adentrar num âmbito reservado para a alta cultura, como revela o comentário de Gullar ao dizer que a contribuição negra à cultura brasileira é clara se pensada em carnaval e futebol, mas não em poesia.

A reflexão sobre como lidar com a intervenção mercadológica que absorve o que o afrodescendente tem de exótico mas considera menor o mesmo elemento se apresentado, por exemplo, no contexto poético, se faz necessária. Embora não seja esta a temática desta tese, aponto, em seguida, o exemplo de Cruz e Sousa, cuja fenotipia pode ter sido um dos motivos para ter os primeiros livros publicados. A crítica ao trabalho do poeta catarinense oscila de acordo com a intenção da leitura dos críticos e com as teorias da época. A publicação de Missal e Broquéis foi motivada 
pelo interesse da editora em obras que de algum modo suscitassem polêmica, como afirma Iaponan Soares em Ao redor de Cruz e Sousa:

Missal e Broquéis foram editados por conta de Magalhães e Cia - Editores, em 1893, quando o país inteiro vivia os dias agitados provocados por insultos do governo de Floriano Peixoto. Além da editora, Domingos Magalhães tinha uma livraria, a Moderna, ambas instaladas nos números 3 e 5 da rua da Quitanda, no Rio de Janeiro. A nova firma estava se iniciando no comércio de livros e, nesse terreno, queria fazer nome de imediato, publicando obras de "escritores novos e mais ou menos escandalosos". Editou, entre outros, o romance polêmico de Adolfo Caminha, O Bom Crioulo, e mais: A Mocidade Morta, de Gonzaga Duque, No Hospício, de Rocha Pombo e a novela O Sapo, de Nestor Vítor. Provavelmente, quando aceitou publicar Cruz e Sousa pensava tirar proveito pelo fato de o autor ser negro. (SOARES, 1988, p.57)

Em "A reinvenção de um passado sagrado na poesia afro-brasileira contemporânea", Steven White introduz o artigo retomando o livro "A poesia afro-brasileira", de Roger Bastide. Publicado em 1943, a parte sétima do livro talvez seja a mais polêmica: nela, Bastide afirma que a descoberta da poesia africana no Brasil foi feita por autores brancos e que os escritores afrodescentes pouco teriam contribuído para o achado inicial. Bastide descreve a "descoberta" dos escritores brancos e o "esquecimento" dos autores negros, afirmando que os sofrimentos da escravização de africanos no Brasil teria sido cantado por autores brancos; a pouca contribuição dos autores negros teria ocorrido tardiamente, sem acrescentar nada de relevante na produção já existente. Afirma ainda que

Seria, entretanto, um erro grave acreditar não exista uma poesia afro-brasileira, com seus traços próprios, seus sinais distintivos e suas descobertas líricas. Apenas a África não é assunto aparente. Ela está, como a filigrana, inscrita na transparência do papel, na textura, na trama da obra escrita, 
no segundo plano dos sentimentos expressos e a sua música é ouvida em surdina, ressonância longínqua e sutil, a cada pausa do verso ou da estrofe." (BASTIDE, 1943, p.129)

A citação de Bastide fala muito sobre o que Ronald Augusto chama de "expectativa ready-made" em "Transnegressão", ao relatar o contato com uma estudante alemã interessada em estudar literatura negra no Brasil. Quando apresentada a um poema caligráfico-visual, a reação da jovem foi perguntar "Onde está o negro neste poema?". Ronald Augusto lê esta como uma variação das expectativas em relação à poesia negra: o típico, o léxico específico (chibata, quilombo, liberdade), o exótico. (AUGUSTO, 2010, p.425). A literatura negra existiria, portanto, só quando se mostrasse às claras, com todos os sinais classificatórios. O crítico se volta para um movimento dentro da literatura que defende uma essência negra, que considera Machado de Assis e Cruz e Sousa como "traidores da essência, digo, da consciência". Augusto prossegue mostrando o quão limitadora e danosa é esta postura:

O grande dano desse traçado programático, delimitador e, de resto, extremamente eficaz para confinar esta prática poética dentro do universo dos estudos culturais e das literaturas de testemunho, é a exclusão sumária de outros textos/autores que apontam hoje - ou que apontaram no passado - para zonas limiares, imprecisas, abertas à sedução da impremanência dos significados, onde ainteligência em movimento costuma puxar o tapete à mediocridade conformadora; o esforço dos poetas/escritores que focalizam sua atenção mais no como dizer e menos, bem menos, no que é urgente dizer talvez ao ouvido do pesadelo da História. (AUGUSTO, 2010, p.426).

Em um contexto literário no qual a urgência de denúncia e reescrita histórica parecem suplantar a experimentação e a liberdade estéticas, as previsões de abertura parecem um respiro. 


\section{UM OLHAR MAIS PERTO}

O intuito principal deste capítulo é apresentar Edimilson de Almeida Pereira. Mesmo sendo um poeta que publica há quase trinta anos - o primeiro livro é de 1985 -, creio que tal apresentação se faz necessária pelos diálogos que a obra de Pereira estabelece com discussões vigentes na crítica literária brasileira, como a formação do cânone literário e os debates sobre Literatura Negra. Após esses tópicos, passo aos antecessores poéticos escolhidos pelo autor, à leitura de algumas das temáticas citadas e à recepção crítica de sua obra.

Certamente é possível traçar outros caminhos para a apresentação de um autor, mas julguei interessante demonstrar como Pereira se desdobra em vários papéis e como reflete continuamente sobre as mesmas temáticas, mesmo em gêneros distintos como a pesquisa antropológica, a crítica ensaística, a produção poética. Essa retroalimentação pode ser percebida desde os primeiros livros de Pereira, o que dá ideia de um projeto alinhavado com base em muita reflexão. Mesmo a recepção crítica de sua obra poética não serve apenas de revisão bibliográfica, pode ser ainda um outro modo de observar como vem se articulando hoje a discussão sobre a Literatura Negra e/ou Afrobrasileira.

\section{1 - Antecessores}

\subsection{1 - Cruz e Sousa}


A escolha de Cruz e Sousa para esta introdução dialógica do capítulo deve-se à necessidade primeira, ao se apresentar um poeta, de tentar situá-lo dentro da produção local, de tentar compreendê-lo na configuração sócio estética de seu contexto; existência de um poeta como Cruz e Sousa, a quem as escolhas feitas custaram muito, é um dos fatores, na Literatura Brasileira, que possibilita os posicionamentos Edimilson Pereira como poeta e crítico - Cruz e Sousa não é apenas um antecessor na poética edimilsoniana, retomando a expressão de Ricardo Aleixo, é um dos caminhos escolhidos por ele, a vertente traçada nas produções da diáspora negra.

Considerando que Edimilson Pereira é um autor (posto que as obras aqui tratadas não são exclusivamente poéticas) cuja vinculação à afrodescendência não pode ser ignorada, mas que também não o engessa, não é a característica única a defini-lo, ficamos na posição de lidar com textos que por vezes são lidos como Literatura Negra e/ou Afrodescendente e apenas isso: é como se o emprego dessa terminologia específica limitasse $o$ reconhecimento das elaborações estéticas perceptíveis nesta produção ou desvinculasse essas elaborações do que é entendido/lido como Literatura Brasileira. De modo sucinto, é como se as questões ou os valores de uma não permeassem a outra. O "emparedamento" do sujeito pelas questões estéticas parece oscilar, nos debates contemporâneos, entre o aprisionamento por uma adesão ao debate político da produção afrodescendente, que dá conta apenas de demandas externas ao texto, e o argumento de que o discurso poético é autônomo, tem regras próprias e perde o apelo artístico se reduzido à função comunicativa imediata.

No ano de 1898, após o falecimento de Cruz e Sousa, foi publicado 
Evocações, volume cujos textos em prosa merecem um olhar atento acerca da carga poética que carregam. No último texto da obra, "Emparedado", acompanhamos o narrador em sua contemplação do anoitecer descrito com uma adjetivação densa, tomado por uma "tristeza fina e incoercível" (CRUZ E SOUSA, 1995, p.658), que suscita rememorações cujo deslocamento ao longo do poema em prosa se assemelha a uma procissão de Corpus Christi; a Solenidade do Corpo e Sangue de Cristo foi criada no século XII para ressaltar a crença no "Cristo todo" presente no pão eucarístico - no Brasil, as ruas percorridas pela procissão costumam ser enfeitadas por tapetes coloridos feitos de flores, sementes e serragem. A alusão ao sacrifício do corpo e sangue não é fortuita: no poema, a imolação é feita com os sonhos não concretizados, a penosa caminhada empreendida rumo ao dia que não chega; o ritmo chega a ser vertiginoso em alguns pontos, como no trecho em que, por estar flutuando na alta e doce paragem das Ideias, o eu-lírico alvoroça "os Preceitos, severos". O sujeito no poema é acusado de ter o temperamento "entortado" para o lado da África, de ser necessário endireitá-lo para a Regra, de não poder ser artista por ser descendente "dos de Cam" (CRUZ E SOUSA, 1995, p.672).

A ascendência étnica do eu-lírico é o principal motivo para a ameaça que recebe: as quatro paredes que se erguerão em torno dele e que aumentarão cada vez mais, permanecendo o sujeito emparedado e alucinado em seu Sonho, caso insista em continuar caminhando - na Frente os Despeitos e Impotências, Atrás a Imbecilidade e Ignorância, à Direita os Egoísmos e Preconceitos, à Esquerda as Ciências e as Críticas (CRUZ E SOUSA, 1995, p.673).

Mas ainda há o conflito por não aceitar os valores estéticos cristalizados que são oferecidos, opondo-se aos "rebeldes em casa", que se dizem rebelados, mas aderem ao jogo de fazer da Arte um modo de 
conseguir prestígio, pagando reverência à Convenção; embora se impulsione contra as fórmulas, o poeta não chega a propor outros valores para lidar com a força tóxica que é a Arte, mas já aponta o conflito de ser poeta negro e ainda escolher outros valores que não os aceitos. A cor da pele, a expressão fenotípica não é o único motivo do incômodo causado: também a insubordinação aos preceitos estilísticos o posicionam como outsider. A apresentação de Cruz e Sousa escrita por Zilá Bernd para a Antologia de Poesia Afro-brasileira coloca o poeta no "Limiar da Consciência", e demonstra que, mesmo que a identidade como negro não transpareça nos poemas mais celebrados, ainda assim é possível encontrá-la:

\begin{abstract}
Se nas obras mais conhecidas não se podem apontar exemplos de um eu-lírico reivindicando sua negritude, isso não quer dizer que a questão do grau de consciência negra de Cruz e Sousa esteja encerrada. A análise do longo poema em prosa, "Emparedado", revela, pela primeira vez na poesia brasileira, uma postura crítica em face da preconceituosa sociedade da época, feita por um negro que assume sua condição de negro "emparedado" no mundo branco, oprimido entre quatro paredes [...]. O poeta de Santa Catarina consegue, na última década do século XIX, propor a reflexão da demolição da ideologia que pretende estabelecer falsos vínculos entre raças (ou cor da pele) e produção de determinada cultura. (BERND, 2011, p.44-45)
\end{abstract}

João da Cruz e Sousa nasceu em Desterro, Santa Catarina, em 1861. A sua criação demonstra o lugar indeterminado no qual o poeta viveu, entre a origem dos pais biológicos, negros escravizados, e a criação dos pais adotivos, família de posses. Conforme descrito, em momentos distintos, por Paulo Leminski e Mara Consuelo Campos, a situação de Cruz e Sousa era bastante particular no que concerne a criação de filhos de escravos no Brasil. O acesso à educação refinada oferecida pelos pais adotivos deu a João da Cruz a possibilidade de desenvolver suas 
habilidades artísticas e assim poder transitar pelos meios artísticos de Desterro.

\begin{abstract}
Anomalia sócio-cultural no Brasil escravocrata do Segundo Império, exceção, desvio, aí temos a matéria-prima para um poeta. Afinal, que é poesia senão discurso-desvio, mensagem-surpresa, que, essencialmente, contraria os trâmites legais da expressão, numa dada sociedade? O filho de Guilherme (escravo) era, agora, o filho de Guilherme (o Marechal do Império). Na confusão dos nomes, entre o pai verdadeiro e o adotivo, muito mistério. A paternidade de João da Cruz fundia-se numa homonímia verbal, irônica em relação ao contexto sócio-cultural. O pai-escravo e o paisenhor chamam-se pelo mesmo nome. (LEMINSKI, 2003, p.20)
\end{abstract}

Foram seus pais o mestre pedreiro Guilherme da Cruz e a lavadeira Carolina Eva da Conceição, negros, escravos alforriados - ela primeiro que o marido - pelo então coronel Guilherme Xavier de Sousa, de quem o menino João da Cruz receberia, como de costume na sociedade escravocrata brasileira, sobrenome e proteção, consubstanciada no apadrinhamento e na educação formal enquanto, paralelamente, os pais continuavam vivendo no porão da casa senhorial. [...] Acolhido no solar senhorial, o menino, nascido de ex-escravos, insere-se numa espécie de entre-lugar social: o de filho de criação ou afilhado, que, não representando, entretanto, igualdade, em relação aos brancos, todavia o destacava, sem dúvida, dentre os demais meninos negros [...]. (CAMPOS, 2011, p.223)

Este "entre-lugar social" destacado por Mara Campos prolonga-se além do período da infância e se imiscui na poesia, conforme Cruz e Sousa começa a desenvolver uma dicção própria. O menino recitando poemas nos saraus da cidade deixa de ser aplaudido como meio de entretenimento quando se transforma no experimentador que nada em sentido contrário às ondas da poesia parnasiana, corrente literária dominante da época. Mas a crítica não era apenas por conta do estilo de escrita mas, como ressalta Leminski, as críticas eram "de aberto racismo: em algumas, Cruz 
chega a ser chamado de 'negrinho mau rimador'" (LEMINSKI, 2003, p.32). Quando deixa de oferecer entretenimento aos locais, o tratamento muda, e não apenas no caso de Cruz e Sousa, mas de outros negros que se lançaram em atividades artísticas.

Por essa época [década de 1888], Cruz e Sousa já sofria as mais variadas formas de pressão social que, logicamente, possuíam raízes raciais. Essas pressões sociais se acentuavam ao caráter inovador do poeta, constantemente em busca de superação de velhos valores, principalmente nas artes e na literatura [...]. Para a sociedade branca de Desterro, era demais sua ousadia ao querer interferir de maneira séria nos meios culturais da cidade. Enquanto João da Cruz era apenas o menino prodígio, com precocidade poética desde os oito anos de idade, recebia convites e mais convites para declamar nos salões de concerto, quiçá como objeto exótico. Mas a partir do momento em que o intelectual Cruz e Sousa passou a atuar, questionando a produção cultural de Desterro, as coisas se complicaram. (GONÇALVES, 1988, p.19)

A referência aos "velhos valores" destacada por Aguinaldo Gonçalves demonstra o período de transição em que a produção literária se encontrava no Brasil: a grande importância e influência do Parnasianismo na poesia da época não dava ao incipiente movimento Simbolista espaço bastante para ser acolhido de outra forma que não com desconfiança e um certo desprezo intelectual.

A batalha estética travada por Cruz e Sousa era voltada para suas experimentações musicais, simbólicas dentro dos estreitos moldes Parnasianos. Junte-se a isso o elemento do preconceito racial que não permitia o reconhecimento da qualidade artística dos afrodescendentes (principalmente no âmbito sofisticado da poesia) e o cenário de criação se configura bastante tenso.

As leituras de Cruz e Sousa não se restringem mais aos elementos 
poéticos mas abrangem atualmente sua concepção de arte, vide os estudos de Mendonça Telles (TELLES, 1994, p.28) e Luiz Silva (SILVA, 1999). Sua recepção oscila com o direcionamento dos estudos da época, sendo lido hoje como grande poeta negro, com o léxico simbolista (branco, neve, etéreas) desvinculado do que se chamou tentativa de branqueamento pela poesia, como escreveu Roger Bastide em um dos vários textos dedicados ao poeta. Cruz e Sousa seguiu a regra poética que vigia no Brasil então (Parnasianismo), mas optou posteriormente pela novidade europeia que the chegou via os franceses simbolistas.

\subsection{2 - Outros Antecessores}

Seguindo o pensamento de Édouard Glissant, a identidade rizomática irá nos ajudar a entender a cultura afrodescendente como um dos elementos, uma das escolhas na obra de Pereira, mas não significará um fechamento. A diáspora negra é tema que permeia toda a obra de Pereira, mas não se trata de um delimitador.

"Como vive o homem, se é certo que vive?" (PEREIRA, 2002, p.18), questionamento que perpassa não apenas este livro, mas, também, os demais, e ecoa parte das pesquisas do poeta e da observação de Sebastião Uchoa Leite no prefácio a Zeosório blues sobre o caráter antropológico da poesia, "não no sentido mais superficial de uma poesia temática e sim no sentido mais vertical que incorpora o ponto de vista nuclear do ser humano como centro das preocupações" (LEITE, 2002, p.13).

O poeta modernista mineiro também aparece através do livro $A$ 
bolsa e a vida, que nomeia o poema no qual a praça é o lugar cuja travessia aponta a possibilidade do assalto. Minas é um lugar carregado de significados, muito além de mero cenário ou paisagem de fundo: é possível reconhecer a geografia e as aflições e ansiedades do lugar, seja as da moça do século XVIII (p.139, Águas), seja o amor que não vinga, em "Magister", p.188. Ainda na entrevista a White, o poeta demonstra como os caminhos linguísticos ligam sua produção artística à antropológica:

As viagens através de Minas Gerais mudaram minha poesia porque abriram caminhos linguísticos e representações culturais ricas pra mim. Lendo os meus poemas você não vai encontrar uma descrição detalhada da paisagem física. Mas a paisagem humana é revelada frequentemente pelos nomes das pessoas como Nelson de Jacó, Geraldo Arthur, Tita, Induca, Manoel Goularte, Orlando Lucas, Zé de Ernestina e muitos outros. (WHITE, 1996, p.50)

Manuel Bandeira tem também uma pergunta duplicada na primeira sessão de poemas de $O$ Velho cose e macera (2002, p.45): "Você me conhece? (Frase dos mascarados de antigamente) localiza cronologicamente os poemas no início do século XX e também um dos personagens principais deste conjunto de poemas, Madame Satã, uma das máscaras utilizadas por João Francisco dos Santos dentro e fora dos bailes e blocos de carnaval do Rio de Janeiro. Bandeira aparece tanto quando "Poema tirado de uma notícia de jornal" (2002, p.81) se transforma em "Poema para uma notícia de jornal", quando da permanência do homem, "O bicho", dificilmente identificado devido à situação de miséria em que se encontra, surge ainda na poesia de Pereira.

Além destes, "Corpo de baile", sessão com três poemas intitulados com nomes de mulheres remetendo ao livro de novelas de Guimarães Rosa; a fala do vendedor ambulante em "signo em rotação", lembrando a 
obra crítica de Octavio Paz, que aparece como poeta no início de Signo Cimarrón, no qual pergunta "¿Quién canta em las orillas del papel?", verso do poema "Arcos". O título de "Na casa de meu pai" pode aludir tanto à passagem do evangelho de João ("Há muitas moradas na casa de meu Pai") quanto ao livro do ganense Kwame Anthony Appiah, Na casa de meu pai. Referências e personagens bíblicos não são incomuns.

As primeiras referências aqui apontadas aparecem mais comumente associadas ao âmbito da literatura escrita. As referências seguintes, dentro das escolhas de Pereira, por sua vez, seguem por um viés não tão conhecido/explorado no cenário da Literatura Brasileira, como na sessão "Passeios", os poemas "divididos" com Ricardo Aleixo e Langston Hughes, este destacado no movimento Harlem Renaissance e na tentativa de criação do jazz poetry, movimento de afirmação identitária dentro da literatura, com a cadência do jazz dentro da poesia servindo para a construção de uma poesia afro-americana pura. O outro diálogo é com Ricardo Aleixo, poeta mineiro com quem Pereira publicou $A$ roda do mundo em 1996, e que fundou, em parceria com Gil Amâncio, a Sociedade Lira Eletrônica Black Maria, que nomeia o último livro da reunião poética 1. Gil Amâncio também fundou a Companhia Seraquê?, cuja peça "De Patangome na cidade" nomeia um dos poemas de Veludo azul (o pantagome, instrumento de percussão típico de Minas, muito usado nas festas de congado e reisado, é como um pandeiro fechado com alças, cheio de contas).

Os poetas e críticos martinicanos aparecem ou em epígrafes (como a referência a Édouard Glissant em "Caderno de retorno", PEREIRA, 2003, p.194) ou com a tomada de versos sem indicação de pertencerem a outrem (como Césaire na mesma obra, com "O que espero deles não é carne/ mas raiz e errância", o último verso presente em Cahier d'un retour au pays natal, cuja referência se reproduz no título do livro-poema de As 
Coisas Arcas).

\section{2. - Edimilson De Almeida Pereira}

Conforme explicado no início deste capítulo, os dois temas escolhidos dentro da produção poética de Edimilson de Almeida Pereira para uma leitura mais dedicada serão explorados no Capítulo 3 da tese. No entanto, para uma melhor apresentação do autor, julgo interessante apontar outros temas que aparecem frequentemente nos poemas, menos como obsessão por parte de Pereira e mais como uma retomada contínua. Um detalhamento dos livros onde esses temas e seus índices aparecem pode ser encontrado na Tabela Temática do Anexo 2, mas passo agora a uma rápida exploração deles, começando com dois poemas da sessão "Paisagens":

NOVA ORLEANS

É necessário ao blues o que na penumbra se chama pelo nome. O blues é uma entre as coisas que se vestem com a própria fome. Com as mãos ossudas de um homem na guitarra. Com a roupa de quem saindo à névoa percebe a vida que o atravessa.

BUENOS AIRES

A María Mercedes e Felix Coluccio

Silêncio no candombe de outros dias, nessa calle. Impossível ver agora os cortejos de reis que, não sendo, eram livre nos bailes, sob os Buenos Aires respiram os fatos. Têm corpos, desejos e nomes. Rosendo Mendizábal e o tango, um incêndio que põe em viagem o sangue.

(PEREIRA, 2003, p.233 e p.235) 
A sessão "Paisagens" engloba treze poemas em prosa constituídos, cada um deles, por um parágrafo ("Genebra", "Havana", "Dublin", "Nova Orleans", "Granada", "Lagos", "Mariana", "Praga", "Cuzco", "Porto Príncipe", "Lisboa", "Marrakech", "Buenos Aires"). Os poemas "Nova Orleans" e "Buenos Aires" se aproximam pela referência a lugares nos quais a herança afrodescendente ou permaneceu ou foi apagada.

Os cenários dos poemas podem ser os mais comuns, mas são lugares onde a vida acontece: o salão abriga funções díspares - é para dançar e também velar o morto. O terreiro é o lugar das oferendas assim como as florestas; a igreja também, embora seja ainda um lugar para o encontro amoroso. A cozinha, centro das casas, destacadamente em Minas Gerais, por conta do calor do fogão à lenha, é também um lugar de acesso diferente na moradia: enquanto a varanda é o espaço entre a rua e o interior, o público e o privado, a sala recebe pessoas não íntimas à família; a cozinha, onde a família se senta, é aberta aos mais próximos apenas.

\section{OUTSIDERS}

Agonia e sorte de

Stela do Patrocínio

Me entreguei à vida e me deram a loucura. Apesar do cárcere o amor se subleva, fala à minha cabeça que roda, se arruma. Aqui onde não sou pessoa me tiram a vontade, não com remédios mas com a ausência que a tudo povoa. Fui vivente no outro lado da cidade, do alto das sandálias me pus a ordenar de sábado a sexta, até perceber nas mucamas a gestação das domésticas. Estive no cinema uma ou duas vezes. Nos edifícios onde me exauri noite e dia olhei o melhor pela entrada de serviço. Meu quarto, sendo quase uma da família, alcançava o céu no além-mar da janela. Apesar disso ser alucinação dos sadios, me deram albergue no 
hospício. Aqui e lá, onde não sou considerada, querem me tirar o juízo com choques, desprezo e sumiço.

O nada, porém, me recupera: reino dos bichos e animais é o nome que assino. Decifrar a floresta de quem me confina ajusta meu destino. Contra eles o amor se enerva, por ironia sou eu a que escreve. Como escrevia nos restos, nas grimpas para não enlouquecer. Sai a porta-bandeira, o operário, a noviça, o pavão real, a sede, um feriado no outro, tudo que em mim gritava e ainda grita. Sai o ator de novelas, os avós, o arlequim, a seleção de passistas. Sai o pai, a Dandã, os que me forma tirados e agora me habitam. Sai um malmequer na ala dos napoleões vencidos, uma bela entre abraços, meu amor como um rio. Apesar dos pesares sou eu a que escreve para salvar, talvez, outros afogados.

(PEREIRA, 2002, p.165)

O poema em prosa refere-se à vida de Stela do Patrocínio, voz poética em "Agonia e Sorte de Stela do Patrocínio" que viveu como interna por mais de trinta anos em um sanatório. As falas de Stela foram gravadas e publicadas como poesia no livro Reino dos bichos e dos animais é o meu nome - no poema de Pereira, a referência ao livro publicado em 2001 aparece no primeiro verso da segunda estrofe.

A começar pelo título do poema, a escolha da palavra "sorte" parece interessante por quebrar um pouco a expectativa da acepção mais frequente do termo em língua portuguesa: ao contrário da sorte como um acontecimento positivo, aqui a sorte é a indicação do destino do eu-lírico que, pela biografia de Stela do Patrocínio não parece nada auspicioso, mas cuja significação se modifica dentro do poema. O transtorno mental do primeiro verso ("Me entreguei à vida e me deram a loucura") não aparece como condição, mas como algo que foi imposto do exterior para a psique do eu-lírico, e que retoma os versos originais da interna: "Estava com muita saúde/ Me adoeceram/ Me internaram no hospital/ E me deixaram internada/ E agora eu vivo no hospital como doente" (PATROCÍNIO, 2001, 
p.51).

É perceptível, na narrativa poética, a reificação do sujeito em ambiente manicomial, o alheamento pelas drogas farmacológicas: "Aqui onde não sou pessoa me tiram a vontade, não com remédios mas com a ausência que a tudo povoa." (PEREIRA, 2002, p.165). O poema aponta outros índices da situação de marginalização na sociedade brasileira, como a manutenção das mucamas do período colonial nas domésticas contemporâneas, "quase da família"; a função da escrita, que serve "para salvar outros afogados", é confirmação tanto da exclusão dos indivíduos quanto da lucidez do eu-lírico, que analisa seu entorno.

Aparece aqui não só a opção de não se restringir ao âmbito afrodescendente como de questionar o que fazem os sujeitos para continuarem sendo, para não cederem a sua condição humana quando tantos discursos os questionam a respeito disso: os Arturos preservam o núcleo familiar, Smith e Joplin cantam, Madame Satã se faz performance, os exilados em manicômios (Bispo do Rosário e Stella do Patrocínio) escrevem, criam: afirmam-se quando são negados. A ideia de falar dos outsiders não é apenas uma parte do projeto de Edimilson de Almeida no qual se inserem negros, performers, operários e músicos, mas engloba junto a esses o discurso do crítico que se constrói ao mostrar que o paradigma apresentado para a leitura da poesia brasileira não é o suficiente para toda a produção poética nacional - tanto que exclui textos como os cantopoemas. As explicações sobre os cantopoemas e o Candombe encontram-se na parte 2.1. Crítica, do segundo capítulo.

Vejamos o caso de Madame Satã, uma das facetas do transformista e capoeirista (negro) João Francisco dos Santos, referência marginal do Rio de Janeiro: no início do século $X X$, a ideia de malandro estava associada ao tipo vadio, brigão; neste caso específico, os signos de identificação desse personagem (chapéu panamá, lenço no pescoço) 
aparecem no poema. Madame Satã aparece após sua morte, com o chapéu e o lenço presentes nas fotos antigas, cercado de músicos, com banda e referências ao carnaval, que the deu a alcunha e a cozinha, com a qual se ocupou no fim da vida; a inconsolável, pois viúva, compõe também a cena (apesar de homossexual, Satã foi casado com uma mulher, teve seis filhos de criação).

No poema, a dor da morte acalma-se no álcool (beber o morto), enquanto o defunto lembra que 'deveria ter os nomes' (2002, p.45) Madame Satã é apenas um dos muitos nomes usados por João Francisco que conta em entrevista que, quando um dos nomes já tinha muitas acusações na polícia, inventava outro.

\section{DIÁSPORA}

Em nós o inca cimarrón marcabrun prefere mil faces as que sendo tíbia hermafrodita desamparo

se estampam fora das revistas

$o$ ancestral madame grou os retirantes

espiam o labirinto em mim se agitam com os lagartos e os táxis acelerados $[\ldots]$ na freagem

Neste momento um migrante de Madagascar é revisado no aeroporto Genève - Toronto - Rio:

- Combien d'argent avez vous?

- Onde a sua carteira de trabalho?

Sob a luz branca ele se esconde na nudez de um pai guineense um noivo brasileiro um neto peruano em outro recinto as indianas as colombianas são adivinhadas como 
se o perigo a tivesse

por atalho.

Alguém esmurrou vitrines

pelos condenados de uma terra

que fruímos lendo textos em sala de aula.

Há tanto amestramos a ira

estamos lentos

como os comboios de ciganos

fáceis de mira como os chicanos.

(PEREIRA, 2003, p.196 e p.211)

Da diáspora negra nas Américas e a subsequente dispersão pelo resto do mundo após as independências das colônias vem a instabilidade em relação a uma base étnica; a utilização da primeira pessoa do plural para indicar o autóctone, o africano e o europeu em "inca, cimarrón, marcabrun", todos latinos, indesejados, espoliados; a "Memória", a "Dança" e a "Fala" contra "a blitz da memória", os elementos de identidade presentes nas histórias antigas de sabedoria cabinda (concha, antílope, velho, tartaruga, forquilha, lagarto, perdiz).

Algumas figuras representam a produção de poesia e crítica fora dos centros de produção cultural, tais como os martinicanos Édouard Glissant e Aimé Césaire, o escritor cubano Juan Francisco Manzano, conhecido na literatura cubana pela biografia do período em que foi escravo. O brasileiro Lima Barreto, cuja biografia de mulato, paciente de hospitais psiquiátricos, produzindo textos durante as internações, liga-se à vida de Stela do Patrocínio, voz poética em "Agonia e Sorte de Stela do Patrocínio"

Um dos temas mais recorrentes na poesia de Pereira é a religião. Para falar deste aspecto, utilizo o seguinte poema:

4/ MISSA CONGA

Para que deuses se reza

quando o corpo aprendeu

toda a linguagem do mundo? 


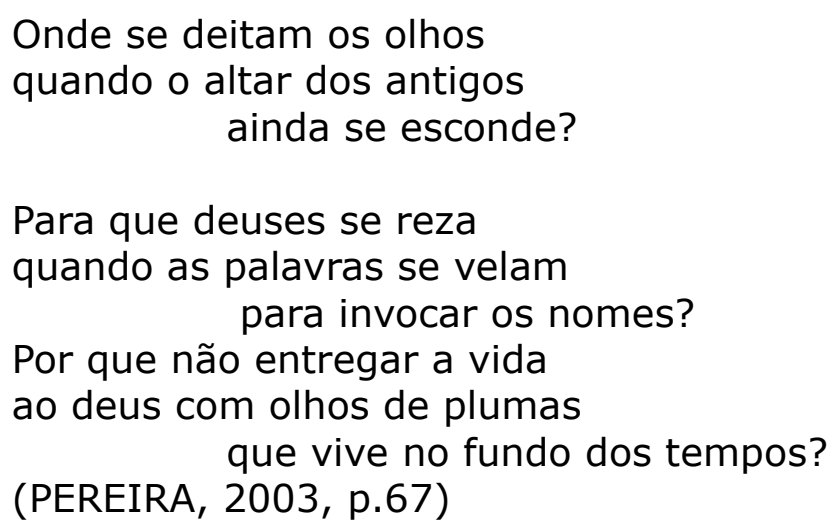

Os deuses jogam paciência, entidades africanas são destinatários de pedidos ("Calunga, me leva pra minha terra"), os principais orixás retratados no Livro de falas, com seus símbolos, remissões às suas histórias, amores, pelejas; São Benedito, o negro, na cozinha dirigindo o mundo. Aos vinte e um anos o jovem foi insultado pela cor que the deu alcunha e, antes e depois de ser superior no convento dos capuchinhos, trabalhou na cozinha do mesmo.

Os três atabaques usados na Umbanda, tratados como orixás, responsáveis que são pela convocação dos deuses ("vai comigo o rum/ o rumpi o lé"). O pai-nosso, os dogmas católicos, as missas, os ritos da Semana Santa, tudo conflui na temática religiosa (não em todos os livros: aqueles de nomes que remetem aos grupos de devoção afro-brasileira celebram sem a interferência da religião oficial - embora a imposição primeira esteja em seus ritos). Mas em Signo cimarrón ganha espaço o Palo Monte, destacado principalmente em Cuba, que deve o nome ("pau") ao material utilizado na confecção dos altares e de estatuetas (pau também pode ser associado a árvore, lugar de habitação dos espíritos na África). Um dos aspectos mais interessantes a ser ressaltado é a organização do culto, feita em "casas" ou "famílias": a separação das famílias sanguíneas no trajeto África - Américas para enfraquecer os escravizados fazia com que a iniciação de um "palero" em uma "casa" ou 
"templo" o inserisse numa "família" não-sanguínea, que se aproxima das práticas dos Arturos pelo aspecto da resistência contra a reificação.

As reflexões sobre a palavra escrita podem ser encontradas em todos os livros de Pereira, mas me utilizo de um poema de Signo cimarrón para ilustrar este tema:

ARTE POÉTICA

LA CONDICIÓN

Juan Francisco Manzano

nació para vivir lo que

es humano. Pero la codicia,

que es humana, le quitó los pasos. Hizo de su cuerpo miseria, testigo de batallas.

Dondequiera que se dijera hombre Manzano era antes esclavo, hijo de la industria

que reduce dulce a amargo, aunque fabricando azúcar ron fiesta tabaco. Juan, así

nombrado, tenía hilos de nomre. Lo cual es augurio si el hombre está em su

nombre como una semilla em la cosecha, mudando y siendo todavía ella misma.

A Francisco le quitaron el lazo de hombre y nombre. A la vez esclavo, lo humano

se dispersa entre listas de nombres que son falsos, pues no aluden a hombres

sino a penas y pesos. Juan Francisco Manzano intenta 
reunir una cosa y otra.

Como se juntan el color y la fruta, musgo y pared, el deseo y la escritura. (PEREIRA, 2005, p.60-64)

A pergunta de Drummond na abertura de O Lapassi... ("Como vive o homem, se é certo que vive?" [PEREIRA, 2002, p.18]) se desdobra nas cenas que perpassam os poemas, nas quais os sujeitos cantam, dançam, celebram, lidam com os policiais que quase inevitavelmente os abordam, bebem os mortos como se tentassem nos mostrar alguns indícios da vida dessas pessoas que também é a moça do século XVIII, sufocada pelo desejo e pelo olhar do pai, ou meninos jogando bola. As dimensões do homem se ampliam de modo a caber não apenas os espoliados, mas todos os que fazem parte da manutenção deste cenário: os conquistadores europeus vistos em "Cabelo" (2002, 107), as vozes do policial e do andante no poema de Veludo azul surgem inicialmente isoladas e depois em duo, ambos fazem parte da cena, ambos parecem sofrer as consequências de um pensamento engendrado, "lei não protege, ata sem mais": mesmo sem saber o que procurar, o policial sabe que determinados elementos, como o cabelo do título, a boca anis e a pele o "autorizam" a abordar o andante, e este percebe, desde o início, a intenção da outra voz.

\section{3. - Recepção Crítica}


De modo geral, a recepção crítica da obra poética de Edimilson Pereira costuma apontar para as seguintes características: a) presença de elementos da cultura afrodescendente; b) o trabalho como antropólogo; c) a formação e atuação com professor universitário. Estas não são as únicas características recorrentes, mas costumam ser as mais apresentadas para caracterizar não só a poesia mas também o poeta. A primeira característica é bastante clara e se configura através de referências a locais, personagens, vocabulário específico, recriação de narrativas, documentos históricos, etc. A segunda é apontada pelo próprio poeta e pelos críticos principalmente quando se trata da leitura de Árvore dos Arturos, obra com fortes reflexos do projeto Minas \& Mineiros. A circulação de Edimilson Pereira no âmbito acadêmico aponta o lugar que ele ocupa fora da posição de poeta: é o lugar da erudição, de um discurso por vezes descolado das expectativas de uma produção literária que trabalha, entre outras coisas, com a cultura afrodescendente. Em algumas críticas costuma ser apontado um menor arrebatamento ao lidar com esta cultura, uma posição menos contudente.

No texto "Viagem à textualidade afro-mineira" publicado em 1989, Ricardo Aleixo (então assinando como Rique Aleixo), ressalta a obra de Pereira, que acabara de conhecer, e de quem futuramente viraria parceiro. Classifica-o como "um dos poucos bons poetas surgidos entre nós nessa década pachorrenta" (ALEIXO, 1989, p. 06), já vinculanda à sua produção poética o trabalho como antropólogo - à época, Pereira já havia publicado, juntamente com Núbia Pereira de Magalhães, o livro Negras Raízes Mineiras: os Arturos. Dos quatro livros até então publicados por Edimilson Pereira, Aleixo destaca Dormundo, o primeiro deles, como livro de formação,

não no sentido que dão os alemães ao romance de 
formação o (Bildungsroman), mas significando, noutra medida, o aprendizado - a um tempo poético e político, mítico e existencial -, a formulação de um discurso, o mundo todo e o outro como possibilidades apenas levemente esboçadas de contato, confronto e - porque não? - síntese. (ALEIXO, 1989, p.06)

Aleixo aponta, na poesia de Pereira, a presença da oralidade africana, que permanece com os griots, e chega a compará-lo com Lèopold Senghor, caso este se desvencilhasse do gosto pelos arcaísmos. Mas a leitura mais interessante de Pereira feita por Aleixo é a da tentativa do poeta em participar das incipientes formulações da Literatura AfroBrasileira

\begin{abstract}
Edimilson que anseia participar da hipótese de uma Literatura Negra no Brasil (área mal demarcada e difusa) não se submete à estreiteza do método de Roger Bastide (leitura temática de uma obra literária escrita por um homem de cor, como nos lembra Antônio Risério, poeta e ensaísta baiano), antes o desnorteia, ao trazer à praça o esboço de uma tecnologia poética especificamente negroafricana ou afro-brasileira, apreendida principalmente na estrutura rítmico-lexical dos cânticos de louvor (orikis) das religiões negras. Conquanto se realiza ontologicamente, a poesia de Edimilson abre também nova frente para o esforço de sistematização do conceito de Literatura Afro-Brasileira, ou Literatura Negra no brasil, como dizem outros autores.
\end{abstract}

(ALEIXO, 1989, p.06)

Posteriormente, em 1990, no artigo "Ô Lapassi e outros ritmos de ouvido: modo de usar", Aleixo aponta o estranhamento presente nas primeiras leituras de Edimilson Pereira e a dificuldade de um poeta mais comprometido com seu próprio projeto poético do que com o "carreirismo literário"; utiliza a expressão "poética edimilsoniana" para definir a poesia de Edimilson Pereira, justificando ser esta a denominação correta para designar uma poesia que recupera "a questão do dizer" (ALEIXO, 1990, 
p.147).

Em Literatura afro-brasileira, o comentário de Maria Nazaré Lima e Florentina Souza sobre a poesia de Pereira indica as várias fontes das quais se nutre sua produção e também uma indica um distanciamento político: "A poesia de Edimilson de Almeida Pereira aborda a questão dos afrodescendentes por um viés menos político, menos contestatório, embora esteja sempre atento aos fatores históricos e às questões sociais." (SOUSA e LIMA, 2006, p.131). Para as autoras, político parece ter uma característica panfletária, menos ligado à noção de político como sujeito inserido em sociedade.

Este trecho aponta uma diferenciação da poesia de Pereira - face às demais produções que poderiam ser lidas como afro-brasileiras, a abordagem do poeta mineiro mostra um movimento diferente, menos centrado nestas questões, ou talvez menos perceptível em seu posicionamento. As escolhas de Pereira, como escrever em espanhol poemas com o nome e as vozes de "Beny Moré" (PEREIRA, 2005, p.50) ou "John Lee Hooker" (PEREIRA, 2005, p.51), fazendo conversar, na mesma língua, sob a égide de uma sessão de poemas intitulada "Orfeo", um dos maiores músicos cubanos e um dos grandes guitarristas americanos, não me parece uma escolha menos política, mas sim um caminho mais exigente na escavação de seus sentidos.

Aponto outro trabalho, este não especificamente tratando da poesia de Pereira mas citando-a como representante da produção contemporânea no Brasil: o pequeno texto, escrito pelo ensaísta Fábio Lucas, "Panorama da Poesia Brasileira Contemporânea" apresenta a atual poesia com um caráter marcadamente fragmentário. Lucas afirma que "a crise do paradigma representa a erosão do sistema literário. Deste modo, desligado do cânone e desfeito o sistema da leitura, o poeta se sente numa espécie de aurora da gênese, ou seja, liberto de qualquer regra ou convenção literária." (LUCAS, $\mathrm{s} / \mathrm{d})$. 
Esses poetas libertos acabam se organizando em pequenos grupos para fazerem circular seus trabalhos através de pequenas editoras e publicações coletivas, alternativa encontrada quando não conseguem penetrar no mercado editorial que busca altos índices de venda. Retomando a relação dos poetas com o cânone, o autor reconhece dois caminhos escolhidos pelos produtores contemporâneos:

Distinguem-se por duas vias tradicionais: o apuro técnico e o respeito pela tradição. Quando leio poetas como [...] Edimilson de Almeida Pereira [...] e tantos outros do mesmo nível, convenço-me da diversidade de manifestações, mas de consciência literária da melhor qualidade. Todas ausentes de um cânone. (LUCAS, s/d)

A ausência dos poetas em um cânone, conforme apontada por Lucas, é a ausência nos "grandes veículos da imprensa". Ou ignorados ou distantes dos meios de legitimação do discurso poético, a alternativa, por vezes, é se juntar a outros produtores para criar/aumentar o círculo de leitores e críticos. Nesse sentido, os poetas podem estar ausentes das grandes editoras e publicações culturais que legitimam um cânone literário facilmente reconhecível, mas esses mesmo poetas criam publicações coletivas, saraus, penas editoras, formas alternativas de circular e constituirem outros cânones. No caso de Edimilson Pereira aponto, além de $A$ roda do mundo (1996), com Ricardo Aleixo, Traduzioni/Traduções (1999) com Prisca Agustoni e o livro-cd Dançar o nome (2000) com Iacyr Freitas e Fernando Fiorese, companheiros do grupo Abre alas, da Juiz de Fora dos anos 1980. Além disso, tanto Variaciones de un libro de sirenas (2009) quanto Homeless (2010) saíram pelo selo organizado por Pereira e Prisca Agustoni na Mazza Edições, o Sans Chapeau. O mais interessante, porém, é a produção de textos críticos sobre a Literatura Negra e/ ou 
Afro-brasileira, nomenclatura utilizada pelo próprio Edimilson Pereira: sem desperdiçar nenhuma oportunidade de fazer este discurso ser legitimado, o autor vai tecendo, com outros criadores da palavra poética, um cânone que reconhece e aponta antecessores, que cria uma tradição e, o mais importante, que abarca criticamente a si mesmo. 


\section{3. "É UM CANTO SILENCIOSO"}

Era mister romper com o Estado toldado das brumas, rasgar as espessuras, as densas argumentações e saberes, desdenhar os juízos altos, por decreto e lei, e, enfim, ressurgir...

("Emparedado", Cruz e Sousa)

je suis un autre avec ma parfeite hallucination a pronunciar uma nova espessura (LINGUAE - Edimilson Pereira)

\section{1 - Ars Poetica}

O fio condutor para este capítulo será o poeta que mescla o projeto crítico ao literário, incluindo ainda os trabalhos como antropólogo visto que, como ressalta o próprio Edimilson de Almeida Pereira, em entrevista concedida ao poeta e tradutor estadunidense Steven White, os escritores interessados na herança afrodescendente no Brasil acabam tendo que exercer também o papel de historiadores, editores, críticos e 
antropólogos, para assim conseguirem desenvolver uma produção bibliográfica sobre a afrodescendência no país (WHITE, 1996, p.53). Um dos exemplos que temos atualmente é Nei Lopes que, além do trabalho artístico como compositor e cantor, é autor de enciclopédias e dicionários sobre culturas africanas e a herança diaspórica no Brasil. A proposta principal deste capítulo é apresentar dois elementos da obra de Edimilson Pereira, sendo o primeiro deles sua concepção de poesia, analisando para tal a construção de uma arte poética encontrada em textos seus e de outrem. Em seguida, analisar com este modo de pensar poesia se desdobra, posteriormente, no estudo dos textos de crítica literária do autor.

Como visto no capítulo anterior, uma das temáticas que aparecem nos poemas engloba personagens outsiders, que são, por diferentes motivos, excluídos no contexto social e econômico. A ideia de falar dos outsiders não é apenas uma parte do projeto poético de Pereira na qual se inserem negros, performers como Madame Satã, operários, pacientes manicomiais, mas reúne a esses o discurso da crítica que se faz ao mostrar que o paradigma literário não é suficiente para toda a produção poética nacional, tanto que exclui textos como os cantopoemas. A produção crítica não é desvencilhada do fazer poético: as personagens estão nas margens, e é por este viés que o crítico busca outras possibilidades de leituras, que o poeta insere outras estéticas (como a do Candomblé). Mesmo sendo capaz de articular/manipular o discurso do centro (e talvez por isso seu trabalho seja tão consistente), Edimilson de Almeida fala da margem.

Neste momento, a ideia principal é depreender, da escrita e leituras de Pereira sua ars poetica, em um levantamento em três fontes. Quando me refiro à leitura, penso numa primeira fonte que são as epígrafes, na qual na qual é possível notar o que autor explicita quando escolhe 
determinadas epígrafes para seus livros, o que ele busca ressaltar apontando esses recortes, se uma indicação dos caminhos anteriores à escrita, se uma chave ou uma senha para abrir os segredos sugeridos pelos poemas; mais explícito desses indicativos é o livreto que acompanha Homeless, com referências musicais, pictórias, poéticas, antropológicas que podem ser encontradas nos poemas do livro (Anexo 1). Retomo a ideia da chave que possibilita a revelacao de segredos explorada por Prisca Agustoni em "Os sete selado na poética de Edimilson de Almeida Pereira" e "Escavações na língua e na cultura". Ao comentar sobre o livro Sete selado, a pesquisadora afirma que

É sintomático, nesse sentido, que o livro se abra com o poema "Senha" (PEREIRA, 2003d, p.143), como se fosse preciso ter um codigo de entrada que permitisse 0 desvendamento do universo. No entanto, nada nos é dado de mão beijada, pois, inclusive coisas comuns têm inscrićões enigmáticas, na medida em que o poema exibe "movimentos que objetivam descamar objetos, mobilizando a memória na decifração de coisas e gentes". (AGUSTONI, 2008, p.18)

Em segundo lugar, mais voltado para a elaboração sobre o fazer poético, temos diversas entrevistas e textos críticos com Edimilson Pereira escrevendo sobre outros poetas ou refletindo sobre os próprios poemas ao responder perguntas de entrevistadores. A terceira fonte são os próprios poemas nos quais se trata do fazer poético, do bulir com a palavra que, diferente do eu-lírico de Drummond em "O Lutador" (José), aparecem mais como jogo, como ritmo do que como batalha. Embora tenham sido apontadas separadamente nesta introdução de capítulo, as fontes serão analisadas conjuntamente, considerando os aspectos e temas que apontam. Importante destacar que estas fontes servirão ainda para a leitura dos três temas que se desdobrarão no Capítulo 3.

Começo com os versos que abre este capítulo, seguindo a conversa 
Edimilson Pereira - Cruz e Sousa apontada no primeiro capítulo. O recorte foi feito para demonstrar como ambos os poetas tentaram "estender o idioma" (PEREIRA apud MARQUES, 2004, pg.65), aceitar o desafio de mostrar algo novo com a linguagem poética. No trecho destacado do poema "Emparedado", lemos: "Era mister romper com o Estado toldado das brumas, rasgar as espessuras, as densas argumentações e saberes, desdenhar os juízos altos, por decreto e lei, e, enfim, ressurgir..." (CRUZ E SOUSA, 1995, pg.662). Este emparedamento do poeta simbolista costuma ser explicado em duas vias: por um lado o preconceito racial, pelo outro a conveção estética de então, o Parnasianismo. No trecho do poema "LINGUAE", lemos um trecho com referência a uma carta na qual Arthur Rimbaud escreve à George Izambard" "je est un autre": "je suis un autre/avec/ma parfeite/hallucination/a pronunciar/uma nova/espessura" (PEREIRA, 2010, pg.118). Não deveria haver, na poesia atual no Brasil, um movimento poético que dite regras de elaboração da linguagem, ditando o que pode ou não ser feito mas, em ensaio de 2010, Pereira afirma o contrário, mostrando uma outra versão do "Emparedado" de Cruz e Sousa, com o desafio:

a Literatura Negra e/ou Afro-brasileira sustenta uma linha pragmática, que circunscreve a pauta de criação, enredando o poeta numa trama na qual ele se vê obrigado a oferecer respostas imediatas às demandas extraliterárias. Nesse caso, a liverdade de experimentação soa como esteticismo alienante, ao invés de se apresentar como recurso para a formulação de novas configurações e interpretações do real. (PEREIRA, 2010, pg.31)

O Poema "39", parte de Ô Lapassi \& Outros Ritmos de Ouvido, pode ser aproximado do título do livro que integra pela forma como o em http://abardel.free.fr/petite_anthologie/lettre_du_voyant_panorama.htm\#je_est_un_autre. 
personagem, o aprendiz de história, atua na realização de sua tarefa. Como lemos no poema,

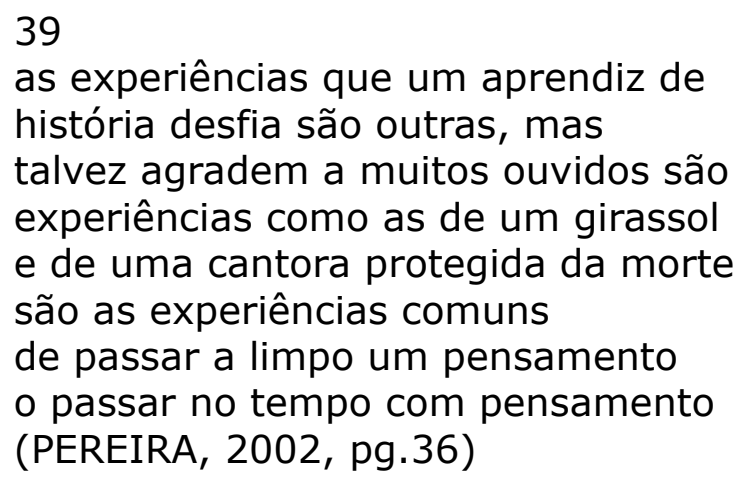

Quando se aprende uma música sem partitura, o aprendizado acontece pela experiência, tal qual aoarece na expressão "tirar música de ouvido", que ajuda a compor o título do livro. Se um músico não tem acesso à partitura de uma música, tenta aprendê-la, escuta cuidadosamente, observa o tom, o compasso, as notas em execução; atentando para a escuta é possível reproduzir uma música aprendida por outro meio que não a descrição formal da partitura, o que é comum se considerarmos que a educação musical da maioria não se faz dentro de conservatórios. Assim acontece também com o aprendiz de história: o mundo não é mostrado a ele decodificado e transparente, mas percebido através de outras experiências. Podemos estender esta noção ao trabalho do poeta, que lê/experiencia outras realidades e tenta transmiti-las.

Embora não esteja claro no poema em relação a qual referencial as experiências do aprendiz de história são "outras" (talvez em relação às histórias excepcionais, visto que as do aprendiz são comuns), não é engano dizer que são experiências relevantes o bastante a ponto de serem narradas para a apreciação dos ouvintes. Essa função sedutora da palavra, que atrai o ouvinte/leitor e busca manter sua atenção, aparece também em "Aula", com uma função bastante prática, a de vender um 
produto: "Três por dois, duas por/ uma - essa sintaxe apraz./ A gente lança no ar. Se der/ ritmo ganhamos a feira, se/ não, fazemos finta de baile." (PEREIRA, 2002, pg.153). No caso destes dois poemas, é necessária a presença de uma platéia, seja somente público ouvinte para as experiências do aprendiz, seja de possíveis consumidores para o vendedor ambulante; embora o intuito inicial, nos dois casos, possa parecer utilitarista, a percepção da estesia é rastreável pelo girassol e a cantora protegida, pela finta de baile.

O poema "Rádio Lata", numa referência a rádios piratas, comunitárias ou não, que existem espalhadas pelo Brasil, traz também a difícil tarefa de conjugar de modo harmônico falas diversas. Conforme lidos nos últimos quatro versos, "Mais difícil que juntar palavras é juntar as/ falas. Nós vós eles tantos, eles e nós di-/ferentes iguais. Essa matemática de um/ verbo veloz." (PEREIRA, 2002, pg.140). A rádio pirata compartilha com o aprendiz e o vendedor ambulante dos dois poemas anteriores uma posição socialmente periférica, que chega à ilegalidade, mas não oculta uma outra intenção desses discursos, que é evidenciar outras vozes; é sempre possível perceber o plural marcando os sujeitos, as vozes nessa poetica.

A inserção de vozes oriundas do contexto oral na expressividade do poema escrito aparece frequentemente na poesia de Edimilson Pereira, como relatado a Fabrício Marques:

Antes de tudo, me dei conta da impossibilidade de registrar a fala por meio da escrita, sobretudo as falas que me tocam, permeadas de desobediência às normas de facilitação da comunicação e, paradoxalmente, tão comunicativas. Os refrões da infância ("Olha o sorvete, moça bonita não paga, mas também não leva") ou os cantos que escutei durante a pesquisa ("Oi, me ajude eu cantar, que me dói o céu da boca"), além de fragmentos de narrativas e conversas me despertaram a atenção para uma prática de metalinguagem 
que se esconde em meio à linguagem figurada. [...] A partir daí, procurei pensar a fala e a escrita não em termos de oposição, mas de provocação. O que há de diferenças entre uma e outra - seja nos conteúdos ou nas formas - é o que nos motiva a procurar uma outra expressão poética, algo entre a fala e a escrita. A possibilidade de que isso não funcione, transforma essa declaração do fracasso mais num horizonte do que num empecilho, pois coloca essa poética em alerta, isto é, na condição das coisas vivas, que precisam se relacionar com o mundo para se dar a ver. (PEREIRA apud MARQUES, 2004, pg. 63-4)

As epígrafes de Veludo azul ("Para tocar no rádio", PEREIRA, 2002, p.78) e Sociedade Lira Eletrônica Black Maria ("Para tocar nas ondas", PEREIRA, 2002, p.126) servem de instruções para a leitura dos poemas: é possível lê-los com o som do rádio da família ao fundo (o cuidado de Edimilson para com seus poemas por vezes os rodeia até com o ambiente/condição de leitura). Essas epígrafes podem ser lidas em conjunto com o poema "Como sintonizar", também pensando em instruções de leitura:

Antes de girar o dial, ligar a cabeça, dentro dela os rios.

Depois trepidar, mesmo que os sons sejam de seda.

Escalar as ondas que se perdem entre conversas.

Rádio é um oceano na sala. Quem o navega conspira contra a ausência, por fala do que vive e arredores. Rádio, equipamento caro. Não pelo teor da moeda, mas por sua incisão no dia. Antes de girar o dial, ligar a cabeça a toda no espaço. (PEREIRA, 2002, pg. 197)

A instrução para ajustar o rádio serve também como caminho para a 
leitura poética: tal qual ouvir música pelo rádio, a leitura aumenta o espaço ("Rádio é um oceano na sala"), ambos dilatam os limites, as fronteiras, as possibilidades. $O$ fato dos sons que enchem o ambiente serem suaves não significa que não sejam capazes de fazer estremecer; a importância do objeto rádio, pelo que provoca ("incisão no dia") e por como é reconhecido pelos ouvintes ("equipamento caro" - caro no sentido de estimado), demonstra como os momentos de prazer ou reflexão provocados pela música são importantes.

As três epígrafes que aparecem em $O$ velho cose e macera estão no entorno musical e cada uma abre uma sessão de poemas do livro. A que abre "Festa" é o título de um poema de Manuel Bandeira: "Você me conhece? (Frase dos mascarados de antigamente)" (PEREIRA, 2002, pg.45). A frase dos mascarados de Bandeira, no meio da festa de carnaval, no qual o jogo das máscaras que escondem o rosto/identidade, permite uma aproximação que poderia não acontecer em outro ambiente, além de ser uma metáfora para as máscaras que usamos todos. O que é selecionado como epígrafe deixa de fora o encerramento pessimista do poema ("Conheço que a vida/ É sonho, ilusão./Conheço que a vida,/A vida é traição." BANDEIRA. 1983, p. 222).

A sessão "Orfeu" traz um trecho da canção "Até quarta-feira", do sambista juizforano Geraldo Pereira: "Sou eu que marco a cadência"; no samba, a função de mestre de harmonia é o motivo para a ocupação durante o carnaval, além é claro de servir como desculpa para o sumiço nos dias de folia: "A batucada começou/ Adeus, adeus/Oh minha querida eu vou/Não sei pra que você chorar/ Se quarta-feira/ Eu tenho que voltar/ Tenha paciência/ Sou eu que marco a cadência/ Da bateria/ Se eu faltar fico mal/ Com o pessoal/ Porque eu sou diretor/ Mestre de harmonia". O recorte feito para a epígrafe ressalta a importância da cadência, da finalização. Continuando com as citações em $O$ velho cose..., A citação à 
frase de Duke Ellington, epígrafe de "Clube", diz que "o blues é sempre cantado por uma terceira pessoa, 'aquela que não está ali' (PEREIRA, 2002, pg.49), aparece também em Muniz Sodré, no livro Samba, o dono do corpo: a explicação oferecida por Sodré é de que a canção é acionada não por aqueles dentro do texto, mas por que está de fora, com a ausência estimulando os ouvintes a preencherem o tempo musical:

\begin{abstract}
A frase do band-leader norte-americano é uma metáfora para a causa fascinante do jazz: a síncopa, a batida que falta. Síncopa, sabe-se, é a ausência no vompasso da marcação de um tempo (fraco) que, no entanto, repercute noutro mais forte, A missing-beat pode ser o missing-link explicativo do poder mobilizador da música negra nas Américas. De fato, tanto no jazz quanto no samba, atua de modo especial a síncopa, incitando o ouvinte a preencher o tempo vazio com a marcação corporal - palmas, meneios, balanços, dança. É o corpo que também falta - no apelo da síncopa. Sua força magnética, compulsiva mesmo, vem do impulso (provocado pelo vazio rítmico) de se completar a ausência do tempo com a dinâmica do movimento no espaço.

(SODRÉ, 1998, pg. 11)
\end{abstract}

Os títulos das sessões que os poemas abrem, "Festa" e "Clube", indicam o contexto de execução da música: aqui não é o blues das plantações, dos spirituals, mas aquele tocado em clubes para entretenimento do público e ganha-pão do músico. O que as epígrafes indicam é a procura de uma pessoa, seja pela incitação feita no poema de Bandeira, da foliã de carnavais passados, que pode ser extendida para locutor/interlocuror mais geral ou para o próprio poema. As epígrafes carregam para a obra poética de Edimilson a pergunta, o inserir de outro que está de fora, ou melhor, a importância do que está de fora, porque é ele quem inicia a combustão da música. Essa inserção do outro se caracteriza como abertura necessária para a realização da troca com o 
outro. Ao retomar a síncopa explicada por Sodré Muniz para fazer entender a epígrafe de Duke Ellington, o poeta afirma que a frase

me faz pensar também na escritura musical do samba, isto é, no ritmo sincopado, que nos leva a preencher com palmas e movimentos do corpo o espaço entre uma nota e outra. Nos dois casos, a ausência poderia corroer as margens do desejo mas, ao contrário, é ela que nos impele à criação. É na dor profunda que o blues e o samba colhem o humor, a auto-ironia e até mesmo a festa. Quer dizer, o ritmo aqui é, antes de tudo, uma experiência dialética, mais aberto às mudanças do que resolvido em si mesmo como uma linguagem para traduzir a posse e a perda, a vida e a morte, a ilusão e o fracasso. Às vezes é terno, outras vezes áspero, intratável. Por isso, "esse ritmo" tem de ser elástico, estando em tudo e em lugar nenhum, preso na caixinha do rádio e livre nas ondas do imaginário. Porque nasce da ausência, ele me situa num constante estado de procura: já não me atrai apenas no sentido musical, mas no de uma vivência com as pessoas e as coisas que, embora presentes, de alguma forma sempre nos faltam. (MARQUES, 2004, pg.63)

Lugares Ares traz, no título da reunião, uma marca de sonoridade bastante forte, com abertura vocálica máxima do [a], que "reforça a impressão auditiva das consoantes que a acompanham"; neste exemplo, as consoantes laterais [I] e vibrantes $[r]$, que formam o título do volume, ajudam Lugares Ares a deslizar quando o nome é dito (MARTINS, 2008, pg.49-57). Talvez essa sensação se contraponham com a "solidão e desalento" que aparecem em Dormundo e são comentados por Iacyr Anderson de Freitas no prefácio à reunião poética 2 (PEREIRA, 2003c, pg.15), mas certamente se encaixa no homem que desaprendeu tudo após o choque do assassinato da mulher e até uma ação corriqueira como andar se transforma numa tarefa maior do que aparenta. O trecho destacado por Edimilson Pereira, "Quando um homem cai sozinho num campo não sabe a quem dar a sua queda", é o final de um dos parágrafos escrito por Clarice Lispector em A maçã no escuro, no trecho "Como se faz 
um homem":

\begin{abstract}
Seus ouvidos ocos tinham sede, e o rumor primário do mar seria o que menos comprometeria o modo cauteloso como ele se tornara apenas um homem caminhando. Porque estendera abruptamente os braços, perdeu o equilíbrio e quase caiu - seu coração pulou em espanto várias vezes. A vida inteira aquele homem tivera medo de um dia levar uma queda numa ocasião solene. pois havia de ser naquele momento que, perdendo a garantia com que um homem fica sobre dois pés, ele se arriscou à penosa acrobacia de voar desajeitado. Boquiaberto, olhou em torno porque certos gestos se tornam aterrorizantes na solidão, com um valor final neles mesmos. Quando um homem cai sozinho num campo não sabe a quem dar a sua queda." (LISPECTOR, 1961, pg.22)
\end{abstract}

Essa situação do homem sozinho, tentando reconstruir-se novamente, é encontrada na poesia de Edimilson com a linguagem que se debruça sobre o que constitui a humanidade do homem, sobre o seu convívio e troca com outros homens. Este elemento, descrito por Sebastião Uchôa Leite e retomado por outros autores ao lerem o trabalho de Pereira, concentra-se numa poesia de "caráter antropológico, mas não no sentido mais superficial de uma poesia temática e sim no sentido mais vertical que incorpora o ponto de vista nuclear do ser humano como centro das preocupações. É esse caráter de integração que o caracteriza não apenas como poeta imerso nas tradições populares, mas como alguém que se preocupa em estabelecer diálogos profundos com as realidades mais diversas." (PEREIRA, 2002, pg. 13). A busca pelo homem é apontada ainda pelos versos de Drummond, "Como vive o homem,/ se é certo que vive?" (ANDRADE, pg.428).

$\mathrm{O}$ índice da Ira, que leio como combustível, aparece vindo de um poema de Osvaldo de Camargo: "Súbito o grito - ô - cresceu depressa/ ante as portas do ouvido, um 'ô' tão longo/ para viver nos séculos". A Ira 
é representada pelo grito que cresce depressa - e permanece, considerando que vive nos séculos. Esse grito é recorrente em outros poemas e também no Cahier d'un retour au pays natal de Aimé Césaire, com o qual Edimilson Pereira dialoga fortemente em "Caderno de retorno". O grito, le cri: inicialmente pode ser tomado apenas como sonoro, como um início, uma abertura a outros gritos, musicais, corporais, caminhos.

A epígrafe seguinte de Dormundo é um recorte do prefácio que Arlindo Barbeitos, poeta angolano, escreveu para seu primeiro livro de poemas, Angola Angolê Angolema, enquanto trabalhava como etnógrafo. No recorte, Barbeitos discorre sobre o silêncio e o início: "Este grande silêncio é talvez o começo de muita coisa, até o fim; é uma espécie de ovo, por assim dizer, é o momento onde pode começar a gestação, onde toda a tempestade 'começa e acaba', 'mas dança' tem vida." (BARBEITOS, 1976, pg. 05). Muito se pode depreender deste prefácio para o reconhecimento do projeto poético de Edimilson Pereira.

A escrita é apresentada como tessitura: coser, costurar, juntar com linha, trabalhar com o tear, as metáforas com os trabalhos manuais comuns às mulheres do interior de Minas Gerais ou como fazer música, sagrada ou secular. O que se quer destacar é que, fazer poesia, produzir obras esteticamente válidas e significativas não é privilégio somente do poeta: da boca dos viajantes, das mãos das tecelãs, do corpo dos jongueiros, da voz das cantoras, da oferta do vendedor de rua, de cada um deles e de todos se percebe um discurso que reflete sobre si mesmo, que busca se elaborar, depurar.

O artesanato é uma das metáforas da escrita mais frequentes na obra de Pereira: sempre há retalhos que se juntam a outros diferentes para formar algo maior como uma colcha; nada é desprezado, mas unido ("como cerzir um país com linhas várias/ onde uma se quebra/ outra a emenda" [As Coisas Arcas, 2005, p.199]); não se despreza o pequeno, o 
miúdo, assim como na poesia de Edimilson de Almeida não se descuida de nada: nem do ritmo, nem do estranhamento causado pela sintaxe, nem os gestos discretos das mãos ou do olhar, sempre carregados de sentidos. Há ainda o elemento feminino, geralmente executor dos trabalhos com tecido. Costurar com os retalhos é não desprezar o que se tem (mesmo que pareça pouco), é transformar em algo significativo, em objeto funcional, valorizado.

Os elementos formais que aparecem mais comumente podem ser exemplificados pelo multilinguísmo, principalmente francês, espanhol e resquícios de línguas africanas presentes nos cantos, com acréscimo de inglês e italiano, bastante explorado em Homeless.

Outros

elementos aparecem como sinal de copulativa comercial (\&), as inversões sintáticas, mescla de gêneros, grafia de português do século XVII, interrogação retórica final, diferenciações ortográficas significativas, como as que aparecem em "Avisos de praça" (PEREIRA, 2003, p.150-152), poema no qual o encolhimento moral do sujeito é representado pela diminuição do seu nome (Affonso Henriques Assis > Affonso Henriques > Affonso $>$ afonso ${ }^{8}$ ), marcas de oralidade (pronúncia cabo-verdiana, dupla negativa), coloquialismo (Quebra Galho > Quebra Gaio > Quebra Gai); aproveitamento gráfico para auxiliar na significação.

\section{2 - Crítica}

$8 \quad$ Em Recitação da passagem, Maria José Barbosa faz uma leitura detalhada deste poema (BARBOSA, 2009, p.154). 
A atuação de Edimilson Pereira como poeta, crítico e antropólogo alimenta-se mutuamente. É possível reconhecermos uma dicção drummondiana na primeira obra, Dormundo, que mais tarde cede espaço para a reação a outros meio poéticos, como os revelados pela pesquisa do Candombe em Minas Gerais. As inserções de cantopoemas podem ser encontradas, principalmente, nos versos de Árvore dos Arturos. Mas o crítico não ficou de fora da equação, como vemos pelos artigos referentes aos cantopoemas questionando os parametros para se entender/estudar poesia brasileira ao sugerir que talvez seja o momento de se atentar mais detidamente à produção afro-brasileira, não como fonte temática para a produção poética, mas ela mesma como produção poética afro-brasileira. Conforme destacado por Maria José Barbosa, o poeta

coloca-se na fronteira enunciativa onde as vozes dissonantes e dissidentes têm o poder de pôr em xeque o conceito da homogeneidade de culturas e literaturas nacionais e canabalizar o que se costuma conceituar como 'tradição literária'. [...] Edimilson questiona o passado como um 'antecedente estético' e o reconfigura como o 'espaço de intersecção' e de enunciação, a partir do qual se recria e se negocia com o presente histórico-cultural.

(BARBOSA, 2009, p.33)

Neste ponto, a discussão sobre o cânone é central para entender não apenas a nomeclatura para a Literatura Negra, ou para demonstrar que esta produção é mais antiga do que parece e que precisa ser documentada dentro da história da Literatura Brasileira. A discussão sobre o cânone do primeiro capítulo serve também para entender porque algumas produções, mesmo com características reconhecidamente poéticas, como comprovado pelo artigo "Poesia no meio da rua, no meio do mar", permanecem fora da categorização como poesia.

Considerando a formação diversa da população brasileira, os vários 
modos de entender e de se relacionar com o entorno, com os diversos povos aqui reunidos, o mais importante - no caso da produção poética de Pereira e do corpus aqui analisado -, as negociações estabelecidas para a convivência simultânea dessas diferentes formas de enxergar o mundo, é no mínimo pertinente tentar observar se os parâmetros utilizados para definir o que é considerado texto literário conseguem abarcar a produção percebida no Brasil ou se as particularidades estéticas de algumas produções acabam sendo negligenciadas por falta de interesse em enfrentar o desafio de análise. A questão levantada por Edimilson Pereira nos textos de crítica literária mais recentes não é especificamente a inserção no cânone literário brasileiro de produções que englobem elementos da chamada estética banto-católica, mas antes de se pensar quais são "as estratégias de formação e transformação" dos fatos estéticos relacionados aos afrodescendentes, ao que acrescentamos o questionamento do que é considerado literatura ou não - antes de tentar definir o que é válido ser lido e estudado, seria interessante observar que fatores são levados em conta na hora de caracterizar um texto como literário ou não.

Embora as práticas religiosas dos Arturos, grupo de origem familiar praticante do Candombe (resultado da junção de práticas africanas de origem banto à devoção a Nossa Senhora do Rosário), não sejam de conhecimento comum e necessitem sempre de alguma explicação sobre sua realização, seu papel como gerador de significação estética é ressaltado na produção crítica de Edimilson Pereira e retomado aqui com o objetivo de levantar alguns aspectos do debate sobre a produção literária brasileira frente ao cânone ocidental, visto por alguns como um conjunto de valores atacados por grupos insatisfeitos e ressentidos com a exclusão de seus representantes deste panteão.

Os objetivos deste capítulo são apontar como, após a pesquisa 
antropológica premiada, nos moldes acadêmicos, o antropólogo voltou-se para a produção poética tendo os Arturos e demais praticantes/práticas do Candombe como personagens, explorando o ritmo e estrutura dos pontos e bizarrias. Em contrapartida, a produção crítica de Pereira aponta agora para um outro viés: a análise dos próprios pontos de Candombe como obra poética silenciosa que necessita de outro instrumental que não somente o da poética ocidental para ser entendida como objeto artístico e, deste modo, auxiliar no enriquecimento da crítica brasileira ao ser capaz de reconhecer elementos da cultura banto na produção poética nacional, uma idiossincrasia comumente ignorada.

Dentro das discussões acerca do cânone ocidental, observamos o trabalho de teoria e análise crítica empreendidos por Edimilson de Almeida Pereira na tentativa de romper determinados limites para englobar as produções de matriz afro no Brasil, especialmente as de origem banto. 0 trabalho elaborado por Pereira estende-se por várias frentes: a pesquisa antropológica junto à comunidade dos Arturos estimulou a criação poética tomando elementos estéticos do Candombe, que motivam agora o pensamento crítico acerca da análise da produção literária afrodescendente.

Partindo deste ponto, o poeta assume o papel de crítico e questiona o tratamento dispensado à produção estética dos cultores do Candombe, entendida nunca como literatura, mas vista ordinariamente com interesse antropológico; com o intuito de justificar a relevância dos cantopoemas dos Arturos como produção literária, o autor elabora uma conceituação acerca da produção estética feita à margem dos parâmetros literários habituais. Não se trata apenas de questionar o cânone, mas de provar, com elementos de análise estética, a possibilidade de inserção de obras outras que não as comumente aceitas.

Algumas vozes retomadas para abrir os livros sequer seriam 
reconhecidas como pertencentes ao âmbito literário ou musical, como os viajantes, os moradores de cidades do interior ou mestres do Candombe que recitam trechos de cantos ritualísticos; como o intento deste levantamento não é se restringir à produção poética escrita, encontramos referências para a construção de um cânone particular que não se limita à presença de autores legitimados, englobando outros autores do fazer poético, numa ampliação do que é entendido como poesia. Em ensaio intitulado "Poesia no meio da rua, no meio do mar" (2003), o autor discute a necessidade de alargamento das fronteiras teóricas para que se contemplem as textualidades executadas com técnicas e visões de mundo distintas das encontradas no cânone literário ocidental. Para tal, volta-se para o griot africano, o songman australiano, o troubadour e jongleur medievais, demonstrando a possibilidade de inserção do cantopoeta brasileiro como produtor de literatura e a existência de uma estética banto-católica (acrescentamos 'brasileiro' mas as inter-relações estéticas entre catolicismo e cultura manifestam-se em toda a América Latina). Essa discussão é retomada em "Cantopoemas: uma literatura silenciosa no Brasil" (2010). Estética e crítica, portanto, caminham juntas no trabalho de Pereira.

O silêncio é um signo recorrente na obra de Edimilson Pereira: o silêncio é pronunciado, ouvido, ressaltado; mesmo os tambores dos cultos afro-brasileiros, por vezes não podendo ser explícitos, soam silenciosamente, como vemos no trecho do poema "Capelinha": Os negros Arturos com seus/ tambores sagrados. Silêncio,/ estão cantando calados." (PEREIRA,2003b p.76). O que lemos em "Capelinha" é a presença de termos sempre ligados ao não explicitamento seja dos atos dos negros, dos Arturos, dos deuses, dos nomes, todos velados, seguidos do canto calado dos tambores. Mesmo que esteja camuflado, disfarçado, o som dos tambores permanece audível, sem ceder ao silêncio. Conforme ressalta 
Pereira em ensaio de 2003, "pode-se dizer que a literatura silenciosa mantém seu significado político-ideológico porque, se por um lado se refere à textualidade de grupos marginalizados em conflito com a literatura legitimada, por outro exige que a alusão ao silêncio seja compreendida como um pretexto para garantir a tessitura de um discurso complexo e criativo" (pg.10). É preciso esclarecer que, no que se refere ao silêncio, o sentido é expandido para conhecimento velado, pouco divulgado; não é preciso "dar voz", voz e sentido os cantopoemas têm, é preciso, por outro lado, saber ouvi-los.

Neste momento do trabalho, optamos por uma leitura mais detalhada de duas obras poéticas específicas: Árvore dos Arturos e Nós, os Bianos, que estão na mesma reunião poética, Casa da Palavra, fato que já os torna próximos, posto terem "familiaridades de tema e estilo", como ressalta Edimilson na "Nota Inicial" encontrada no início de todas as reuniões poéticas (PEREIRA, 2003b, p.17); além destes, utilizaremos fragmentos de poemas recolhidos em outras obras nos quais percebemos um trato mais acurado dos temas da família e da religião, bem como observar as estratégias estéticas de matriz banto-católica, apontadas por Pereira em Um tigre na floresta de signos $^{9}$, cuja leitura dialógica com os livros escolhidos mostrou-se enriquecedora.

Como continuação dos estudos antropológicos conjugados às produções poética e crítica, Edimilson Pereira desenvolveu um conceito em torno da expressão "estética banto-católica" que pode ser encontrado em alguns artigos escritos no decorrer dos últimos anos, dos quais ressaltamos: "Cantopoemas: uma literatura silenciosa no Brasil", de 2002 (expandido para ser publicado no livro de 2010); "Poesia no meio da rua,

\footnotetext{
9 O título do livro é uma alusão a parte IV, "Correspondences", de Spleen et Idéal, de Charles Baudelaire. In: Les fleurs du mal. Paris: Le livre de poche, 1999, p.55. Os versos do poema fazem referência a "a natureza 'é um templo', onde o homem passa 'através de florestas de símbolos' e 'os perfumes, as cores e os sons se respondem."
} 
no meio do mar: notas sobre ritualidade e estética na cultura afrobrasileira", no ano subsequente; e os artigos de Um tigre na floresta de signos, obra organizada pelo próprio poeta, que demonstra na introdução ("Negociação e conflito na construção das poéticas brasileiras contemporâneas") como a literatura de expressão afro se inseriu no contexto nacional: "Foi, portanto, na aflição e na transformação da poesia brasileira em 'outra coisa' que a Literatura Negra e/ou Afro-brasileira, delineada a partir da obra de determinados autores, se articulou, rasurando o cenário da literatura brasileira contemporânea." (PEREIRA, 2012, p.16).

No final dos anos 1980, junto a professora Núbia Pereira Gomes, Edimilson Pereira teve contato próximo com as celebrações do Candombe e do Congado em Minas Gerais, resultando daí a escrita de vários trabalhos acerca da cultura popular afrodescendente, que se expandiu em seguida para aspectos outros que não os religiosos. As obras mais significativas de Pereira advindas destas viagens foram, no âmbito da antropologia, Os tambores estão frios: herança cultural e sincretismo religioso no ritual de Candombe (2005); Arturos: olhos do Rosário (1990) e Negras raízes mineiras: os Arturos (1988), os dois últimos em coautoria; o primeiro livro é estruturado de modo bastante formal, apresentando o Candombe pelos vieses linguístico, histórico, antropológico, oferecendo ao leitor a apresentação de diversos pontos ritualísticos, suas funções, narrativas de fundação, aspectos técnicos de confecção dos tambores e mesmo os questionários elaborados para as entrevistas com os devotos; todas as informações que oferece se mostram valiosas ao se fazer a leitura dos poemas de Pereira.

$\mathrm{Na}$ hierarquia da fé, os reis congos são os chefes supremos, ocupam postos de honra ao representarem Nossa Senhora do Rosário e as nações africanas; os capitães, detentores de conhecimento, devotados, são os 
condutores dos cantos, guardam os segredos do Rosário (PEREIRA; GOMES; PEREIRA, 1990, p.17). Dentro do Candombe, tão importantes quanto os devotos são os elementos que os mesmos lutam para manter, como os três tambores sagrados, Santana, Santaninha e Jeremia, que representam a resistência negra, chamam os antepassados (sendo, portanto, intermediários entre vivos e mortos); conforme ressalta Leda Maria Martins, na cultura banto não há cisão entre secular e sagrado, história individual e memória coletiva local: no saber deste grupo, o indivíduo é constituído pela tríade dos ancestrais fundadores, divindades e "outras existências sensíveis" combinado ao grupo social e a série cultural (MARTINS apud LUCAS, 2002, p.49); A sacralidade dos instrumentos do Candombe se percebe na proibição de se usá-los fora do rito: mesmo aqueles industrializados se tornam sagrados e não podem ser tocados fora do ritual.

A dança por vezes se transmuta para reproduzir os gestos dos escravos que mudavam o comportamento quando um estranho se aproximava, fingindo serem picados, indicativo de que era necessário camuflar "dos de fora" as práticas religiosas não aceitas. As celebrações do Candombe (que faz parte do Congado) são analisadas como resistência através do sagrado, mesmo que já não seja mais possível manter os elementos tais como eram antigamente (alguns instrumentos não são mais fabricados pelos fiéis, mas comprados industrializados e tornados sagrados), mas "a sabedoria dos descendentes está em conviver com o antigo e o novo, criando tempo e espaço propícios para o desenvolvimento de uma ordem social que dignifique os seres humanos e o mundo em que vivem." (PEREIRA, 2005, p.22). Como descrito na introdução da obra, a manutenção do antigo e a convivência com o novo geram equilíbrio na prática do Candombe - podendo-se utilizar este equilíbrio entre o antigo e o novo como modo de entender a poética de Pereira. O intuito 
antropológico de sua obra é demonstrar a fragmentação cultural de alguns grupos étnicos, o sincretismo religioso e as tensões perceptíveis através do rito do Candombe, além de abordar a reelaboração identitária dos afrobrasileiros.

Embora o livro avance para especificidades dos grupos praticantes do Congado principalmente em Minas Gerais, vamos nos ater aos elementos comuns entre eles e algumas características próprias dos Arturos. De modo geral, os candombeiros gozam de prestígio na comunidade por deterem um conhecimento antigo que os diferencia dos praticantes dos demais rituais: embora um devoto do Candombe participe de outras festas, os praticantes das outras festas nem sempre são iniciados capazes de "bulir com os tambores". A fala dos mesmos obedece a uma organização sintática própria, assim como a organização fonológica empregada pelos devotos. O ritual que une santos católicos e antepassados pode ser celebrado tanto em lugar delimitado quanto livre, conforme a descrição abaixo:

quando é realizado na capela ou no terreiro, os tambores são fixados num determinado lugar e a partir deles se abre a roda. Os cantadores entram na roda, tiram os pontos e retornam para 0 grupo de pessoas localizadas nas proximidades dos tambores.

Quando o Candombe sai às ruas, tem-se a formação no mesmo estilo das guardas ou ternos de Congo e Moçambique: são duas filas indianas, lado a lado, tendo ao centro e à frente o capitão que tira os cantos. (PEREIRA, 2005, p. 65)

Observa-se uma maior inserção de mulheres e crianças no Candombe mais recente, o que não ocorria antes, visto serem os homens a maioria dos iniciados; além disso se destacam, como elementos comuns à prática, a transmissão do conhecimento antigo através do canto, da 
dança e das narrativas, a celebração dos antigos sem incorporação, a divisão dos cantos entre pontos (de demanda ou porfia), que servem para desafiar outro candombeiro e a bizarria, voltada para a brincadeira.

Outro livro que destacamos, Arturos: olhos do rosário, dirige suas atenções para um grupo específico dentro do Candombe - a família constituída por Arthur Camilo Silvério e a esposa, Carmelinda Maria da Silva - residentes da região de Domingo Pereira, próxima ao município de Contagem, região metropolitana de Belo Horizonte. Nesta obra, escrita com Núbia Pereira Gomes e repleta de fotografias de Marcelo Pereira, a apresentação dos Arturos se mostra mais aproximada, não apenas pela descrição de outras celebrações da comunidade (das quais falaremos abaixo), ou por termos mais imagens dos rostos, capturando feições e risos, mas pelos descendentes do tronco iniciado com Arthur Camilo serem apresentados não unicamente por suas funções dentro do Candombe, mas pelas representações poéticas de Edimilson de Almeida que culminaram, no ano de 1988, no livro Árvore dos Arturos. Nos "Retratos de Família", as fotos dos filhos de Arthur Camilo, vestindo ou não suas indumentárias celebrativas, são acompanhadas de poemas referentes aos devotos, que relembram dos ensinamentos e gestos do pai e indicam seu papel dentro da hierarquia das festas, misturando o som de gungas às contas da Senhora do Rosário, onde moram os olhos de Zambi (PEREIRA; GOMES; PEREIRA, 1990, p.23).

A apresentação dos Arturos se faz lembrando alguns aspectos fundamentais: a presença deste grupo familiar em Minas Gerais se deve à vinda forçada dos africanos para um solo desconhecido cuja trajetória não se fez somente pelo caminho marítimo, mas também através da resistência afetiva, na construção e sedimentação da família e na celebração religiosa, indissociáveis, tão inserida está a prática da fé no cotidiano dos Arturos, daí o epíteto dado no título da obra: por 
vivenciarem a ligação primordial entre criatura e Criador, por verem na Nossa Senhora do Rosário - a Grande Mãe - o motivo para continuarem a viver, a resistir, são eles os "olhos do Rosário" que a protetora carrega nas mãos.

No fim do século $X V$, os dominicanos introduziram na África a devoção à Nossa Senhora e a reza do rosário como estratégia de catequese; quando os africanos escravizados vieram para o Brasil, o modo de coibir as expressões de religiosidade africana e simultaneamente incutir as práticas católicas foi incrementado no século XVIII com a devoção a santos negros, como São Benedito e Santa Efigênia (que teve, inclusive, uma capela construída em Vila Rica por Chico Rei, monarca africano que teria vivido como escravo no Brasil e, fazendo-se liberto, ajudou a libertar outros negros, tendo sido coroado rei da festa da Senhora do Rosário pelo bispo de Diamantina). Como participantes das Irmandades de santos negros ou de Nossa Senhora do Rosário dos Pretos, os negros, escravizados ou libertos, podiam praticar rituais africanos (como as coroações de reis e rainhas) junto aos ritos católicos, assim como realizar as danças e os cantos próprios, mantendo os instrumentos. A flexibilidade no sentido de permitir a prática de ritos africanos junto ao processo de cristianização servia como forma de controle e submissão dos escravos. Os negros, por outro lado, aproveitaram para continuar inserindo sua concepção de mundo no modelo a que eram expostos; a permissão dos encontros religiosos serviu como oportunidade para elaborarem a sua música (LUCAS, 2002, p.44).

Estamos analisando aqui a edição de 2003 de Árvore dos Arturos (in: Casa da Palavra: obra poética 3), reformulada desde sua primeira publicação, em 1988, pelas Edições d'lira. O autor empreendeu mudanças para a recente publicação da obra: os textos apareceram mais enxutos, os trechos de pontos de Candombe foram destacados do corpo dos poemas, 
como para mostrá-los mais autônomos, merecedores de observação mais atenta; modificaram-se termos (sinhá<diá). Na peça de abertura encontrada na reunião poética de 2003, lemos:

\author{
CURIANGU \\ Silêncio veio no \\ raio. \\ Os ossos voltados \\ para o mundo. \\ A família surgiu na \\ floresta rubra. \\ São pequenos de mãos pequenas, adultos \\ antes do tempo. \\ Os meninos criaram \\ memória \\ antes de criarem cabelos. \\ (PEREIRA, 2003, p.53)
}

O título deste poema remete a um momento específico do dia: o curiango é uma ave de hábitos noturnos, assim como noturnas são grande parte das celebrações dos Arturos. O poema traz signos caros à Pereira, comumente usados na construção dos cenários em que transitam os devotos do Rosário, tais como o silêncio que não se pode ignorar, vindo num raio, luminoso: é silêncio e tem força, faz-se presente, insere-se através da luz do raio, ao mesmo tempo em que se situa nas frações de segundo anteriores ao ruído do trovão.

É interessante perceber que este silêncio se apresenta tão potente quanto a trovoada ou a faísca de luz do raio; então, no meio do silêncio e da noite (dois índices bastante fortes de ocultamento, de segredo) é que nasce o embrião dos Arturos, "os ossos voltados/ para o mundo", uma abertura e não um encerramento dentro das práticas religiosas. Esta abertura, o voltar-se para o mundo, foi essencial para a sobrevivência das 
práticas africanas herdadas: caso optassem por um essencialismo para manterem os cultos sem alterações, corriam o risco de vê-los perecer, dada a conversão forçada ao cristianismo; o sincretismo religioso é uma forma de continuidade ao agregar o novo, no caso, elementos da religião oficial; mas o "voltar-se para o mundo" é também entender o sagrado como intimamente ligado ao profano, ou melhor, como uma vivência do sagrado que não exclui de si o mundo, mas faz do mundo o lugar no qual a prática se presentifica.

A importância do segredo nas práticas religiosas dos afro-brasileiros e a situação marginal em que ainda se encontra o reconhecimento da cultura afrodescendente, leva a uma leitura do ocultamento da significação dos ritos como uma forma de defesa:

Pedindo nós a tradução de uma cantiga, Manuel Pedro foi logo respondendo: - "Dessa daqui só posso dizer que ngombe é boi. O mais, não". Tudo fizemos para lhe arrancar o segredo. Advertimos que, entre homens, podia proferir qualquer palavra, ainda a mais indecorosa, mas nada. - "Eu não posso ensinar. Meu mestre não me ensinou. Mandou outro. Nem todo fundamento ${ }^{10}$ a gente pode dar." (MACHADO FILHO, 1985, p.67)

A família que surge em meio a uma floresta rubra, que remete não apenas à multiplicidade de espécies, mas ainda aos muitos significados que se encontram na linguagem poética, vem toda corporificada pelos meninos: são eles os que amadureceram forçados ("adultos/ antes do tempo") pelo trabalho extenuante na nova terra, e são eles que carregam os antepassados ("criaram/ memória/ antes de criarem cabelos"). A primeira versão do poema, "Mata do Curiangu", traz o dado espacial que localiza o lugar de surgimento do grupo, além de 7 versos e uma estrofe a mais; para a versão mais recente, subtraiu-se verbos e adjetivos,

10 Fundamento: tradução sumária. 
procurando não desperdiçar palavra sequer para reproduzir a gênese do grupo: as palavras parecem ter crescido, tão carregadas de sentido, que os versos mais curtos nos retém por mais tempo para, olhando de perto, conseguirmos captar o que dizem.

A raiz que gerou a árvore familiar representada no livro de poemas é Arthur Camilo, cuja memória é mantida pelos filhos, relembrada para não se perder: o núcleo gerado por ele se fez forte através da união dos descendentes, da celebração da fé e da resistência da festa. Ao contrário do que se propaga a respeito dos afrodescendentes no Brasil, a presença do grupo familiar se percebe ainda no período da escravidão.

Após sinalizar o surgimento na floresta, abre-se clareira num ponto específico e nos vemos inclinados a observar o elemento central desta árvore, a ligação Arthur Camilo Silvério com os familiares, contada na sessão "Árvore de Arthur Camilo", composta por três poemas de três estrofes cada, com o ritmo marcado estabelecido pelos refrões de cada poema. Inicia-se a descrição da árvore pelo "Tronco" (p.54), expandindose com a "Companheira" (p.54) para se alongar nos galhos, "Arturos" (p.55). No caso específico de Arthur Camilo, nascido após a Lei do Ventre Livre, mas afastado do convívio paterno para morar na casa do padrinho que se incumbiu também de ser patrão, o empecilho de praticar as ligações familiares foi o que o fez lutar para a solidez da família dos Arturos. Tendo morrido o pai numa localidade próxima à fazenda na qual vivia com o padrinho (devido, aparentemente, mais ao trabalho servil prestado do que à ligação religiosa), o jovem, diante da negativa ao pedido de ver o pai morto, insistiu, chorou, mas o patrão/padrinho continuou a negar e, para encerrar a questão, quebrou-lhe os dentes, porque "negro não tem sentimento"; quando chegou o momento de constituir a própria família criou os filhos unidos para que o pertencimento se fizesse forte (PEREIRA; GOMES; PEREIRA, 1990, p.13). Dentro da 
formação familiar que concretizou Arthur Camilo, foi passada aos descendentes a devoção à Nossa Senhora do Rosário e a prática do Candombe. Eis o primeiro poema desta sessão:

\author{
1/ TRONCO \\ Meu pai se chamou Camilo \\ na chuva dos dias quebrados \\ conheceu minha mãe Felisbina. \\ Minha mãe não sei de onde veio \\ sua vida permaneceu comigo \\ o riso mais tarde é que veio. \\ Meu pai se chama Camilo \\ e na sombra dos dias perdidos \\ encontrou minha mãe Felisbina. \\ (PEREIRA, 2003, p.54)
}

No poema "Tronco", os pais são nomeados e o encontro entre eles é lembrado. Destacamos aqui o verbo referente ao pai: o pretérito perfeito "chamou", na primeira estrofe, situa a figura paterna num passado já findo, ao qual se retorna apenas com o recurso da memória; na última estrofe, o "pai se chama Camilo" e se presentifica não só pela lembrança, mas pela vivência desta lembrança, da sabedoria com ele aprendida; da mãe não se sabe a origem e as memórias parecem poucas, mas a herança mais importante, a vida, segue com o eu poético. Podemos distinguir uma cisão temporal no texto: o encontro dos genitores se dá em meio à sombra, à chuva, aos dias quebrados, tudo remete ao desconsolo, à fragmentação. Nos versos que indicam o vislumbre da mãe pelo pai, no final da primeira e terceira estrofes, o tempo se abre para o futuro: "e na sombra dos dias perdidos/ encontrou minha mãe Felisbina", os versos servem como prenúncio do alívio encontrado no bem-querer e nas possibilidades que este encontro carrega consigo. O conectivo " $\mathrm{e}$ " mostra 
a junção entre os dois, mas também a continuidade no filho.

Seguindo os poemas, Arthur Camilo é o tronco de onde saem os Arturos, com ele começa a valorização familiar; podemos aproximar este poema a outro presente em Signo cimarrón, livro publicado por Edimilson em 2005: o poema encontrado na página 56, "Palo Monte", desdobra-se ao detalhar as formas que são usadas para chorar os mortos. O nome do texto refere-se aos "Palo" ou "Las Reglas de Congo", grupos de origem banto organizados por escravos vindos da África Central para a República Dominicana, podendo ser conhecidos ainda como Palo Monte, Palo Mayombe, Brilhumba, Kimbisa. O nome palo (pau) é dado às estátuas ou aos altares, construídos em madeira e é equivalente a árvore, local habitado pelos espíritos na África. O ritual de iniciação acontece no que chamam de "templo" ou "casa", como são chamados os grupos dentro da religião, organizados tal qual uma família, o que foi tomado de forma literal após a separação das famílias sanguíneas pela escravidão. Como vemos, as semelhanças entre as práticas religiosas de matriz afro que se espalharam pelas Américas não é apenas na manutenção de crenças (a referência ao palo, ao tronco que carrega consigo os antecessores), mas no esforço em se manter núcleos familiares, seja por identificação religiosa - como os escravos na República Dominicana, seja pelos laços sanguíneos, como no caso dos Arturos.

As atividades do Congado - no qual se insere o Candombe começam após a Semana Santa com a abertura do Reino e terminam em outubro ou novembro; conforme explica Leda MARTINS e Afrografias da memória, os Reinados são

definidos por uma estrutura simbólica complexa e por ritos que incluem não apenas a presença das guardas, mas a instauração de um Império, cuja concepção inclui vários elementos, atos litúrgicos e cerimoniais e 
narrativas que, na performance mitopoética, reinterpretam as travessias dos negros da África às Américas. (MARTINS apud LUCAS, 2002, p.20)

Vale ressalta que, para os fiéis, o Reinado é religião e não manifestação folclórica: para eles, folclore é uma forma pejorativa de referência, usada ao se tratar daqueles grupos que se distanciaram dos fundamentos.

Por se tratar de uma celebração com grande importância para o grupo retratado nos poemas, consideramos importante detalhar como se desenvolve a abertura do Reino: na comunidade dos Arturos, o Reino é aberto no domingo de Páscoa ou no seguinte; quando o reino se fecha (a partir do mês de outubro ou novembro), os tambores não são tocados e não há festas, mas com o reino aberto "as guardas são solicitadas para vários compromissos que incluem rezar Missas Congas em outras localidades, hastear bandeiras ou rezar terços para o cumprimento de promessas de devotos, comparecer às festas de outros grupos para retribuírem visitas, etc" (LUCAS, 2002, p.62). A festa do Reinado, próxima ao dia de Nossa Senhora do Rosário, 7 de outubro, é indicada com o hasteamento do mastro de aviso duas semanas antes do início das celebrações; nos dias seguintes os demais mastros são erguidos. $\mathrm{Na}$ sexta-feira à noite os Arturos batem o Candombe; no domingo, as caixas de Moçambique acordam os fiéis para a alvorada, caminhando dentro da comunidade em direção às casas dos reis e rainhas, dirigindo-se posteriormente para a Igreja de Nossa Senhora do Rosário, cantando ao pé do cruzeiro. Retornam para o café e, de volta à capela, trajam as vestes próprias para o ritual, as guardas se organizam e, separadamente, partem para buscar a corte, reunindo-se depois para formar o cortejo que segue até o local da Missa Conga. Com o fim da missa os fiéis voltam à capela para, com cantos, encerrarem o dia. Na segunda-feira o cortejo 
segue de manhã e, após o almoço, iniciam-se os rituais de agradecimento que indicam o fim da festa. À tarde ocorre o pagamento de promessas e, à noite, depois da missa, os "reis festeiros" (aqueles que serão os reis do ano seguinte) são coroados e recebem dos "reis de ano" as coroas e mantos, abençoados pelo cortejo, por Deus e por Nossa Senhora (LUCAS, 2002, p.64).

São muitas as festas ou vivências do sagrado praticadas pelos Arturos, mas ocorrem de duas formas - no caso do Batuque, do Candombe e do João do Mato, a celebração é interna, familiar; a festa da Libertação, do Rosário e da Folia de Reis são festas de cortejo, para o público, celebradas externamente, para recriação do sagrado. Um elemento presente nos dois tipos de celebração é o mastro, encimado pelo estandarte com os santos de devoção, erguido antes das festas de cortejo para indicar o centro energético da celebração e os lugares destacados, como em frente às capelas, às casas dos capitães, diante da casa de um mestre já falecido, defronte à Igreja do Rosário (este acompanhado de dois mastros indicando um a guarda do Congo, o outro a de Moçambique). Em torno do mastro, representativo da verticalidade que une terra e céu, vivos e mortos, corpo e espírito, os devotos dançam recriando as reuniões em torno do fogo sagrado, formando o círculo que indica perfeição e integração (PEREIRA; GOMES; PEREIRA, 1990, p.42).

A Festa de Nossa Senhora do Rosário, celebrada no mês de outubro, é compartilhada por grupos negros praticantes de Congada, Congos ou Conga, englobando também a celebração de santos negros como São Benedito e Santa Efigênia, e se espalha por várias regiões do país além de Minas Gerais. A devoção mescla a fé em Nossa Senhora (que teve o culto imposto na África pelos dominicanos) com a coroação de reis, a dança dos guerreiros, refazendo as práticas da Terra-Mãe; o resultado se deu, portanto, da fusão entre a religião branca e a recriação dos afro- 
brasileiros. Existe mais de uma versão para a origem do culto praticado entre os Arturos; destacaremos os elementos da fundamentação mítica que servem como importantes chaves de leitura para os poemas de Pereira. Num das versões, o resgate da imagem de Nossa Senhora ocorreu em Argel e a identificação de Nossa Senhora com os negros se confirmou quando Ela resolveu com eles ficar: os ricos tentaram atraí-la com banda de música, o padre com missa e pregação, mas a imagem pouco ou nada se moveu no mar.

Uma variação conta que os brancos tiraram a imagem da água por diversas vezes para colocá-la numa capela ricamente construída mas a santa, invariavelmente, desaparecia do lugar e voltava às águas. Quando conseguiram autorização dos senhores para tentar levar a imagem à praia, os escravos construíram seus instrumentos (os três tambores Santana, Santaninha e Chama - mais cuíca e chocalho) com folhas e cabos encontrados no mato; como narra o capitão João Lopes, da Irmandade de devotos do Jatobá, em depoimento à Glaura Lucas, "fizero o oratore de sapé, pusero arco de bambu enfeitado pra ela passá e foro bateno os tambô, cantano, dançano pra ela [cantavam na sua própria língua]: 'anaruê, okunda tunda dandolê de carunga uiá, anaruê oiê akunda akunda oreia di carunga anaruê." (LUCAS, 2002, p.57). Com seu canto, os escravos conseguiram trazer a imagem para dentro de sua roda, mas a estátua foi tomada pelos senhores, que a levaram para a capela. A santa fugiu e refugiou-se na construção de sapé erguida pelos escravos, sem luxo, e de lá não mais saiu; dizem que Santana, o tambor sagrado, foi o lugar escolhido pela imagem para se sentar.

São duas as guardas da festa, uma das mais importantes para os Arturos: a guarda de Moçambique e a de Congo; na região metropolitana de Belo Horizonte a versão mítica divide as guardas entre as que conseguiram os primeiros movimentos da imagem e a que a retirou das 
águas, diferenciadas pela fundação mítica, cujo desenrolar é descrito no trecho abaixo:

\begin{abstract}
as guardas se formaram ainda em África, quando uma imagem de Nossa Senhora do Rosário apareceu no mar. O grupo do Congo se dirigiu para a areia e, tocando seus instrumentos, só conseguiu fazer com que a imagem se movesse uma vez: num movimento rápido, Nossa Senhora se encaminhou para frente e parou. Então vieram os negros moçambiqueiros, batendo seus tambores recobertos com folhas de inhame, cantando para a Santa e pedindo-lhe que viesse para protegê-los. A imagem veio se encaminhando, no movimento vai-vem das ondas, lentamente, até chegar à praia. (PEREIRA; GOMES; PEREIRA, 1990, p.47)
\end{abstract}

A diferenciação na fundação mítica é reproduzida na função e no vestuário das guardas, com o Congo vestindo rosa e verde (as flores e galhos representando o caminho para a Senhora passar), desloca-se puxando os dançantes com movimentação rápida, como fizeram com a imagem nas águas, conduzindo o trajeto carregando espada e tamboril, instrumentos que movimentaram a imagem. O Moçambique, por sua vez, trajado de branco e azul (as cores da santa), guarda a Grande Mãe "representada pelos reis cujas coroas a guarda conduz" (PEREIRA; GOMES; PEREIRA, 1990, p.47), carregando o bastão, que indica poder por terem conseguido mover a imagem até a praia. Pela dança e linguagem dos cantos também se percebe as diferenças das guardas: com bailado rápido, saltitado, cruzando pernas, deslocando-se lateral e pendularmente, os Moçambiqueiros, guarda mais antiga e, por isso, executores da música secreta, da memória africana e dos antepassados, têm o canto mais improvisado. No Congo, em contrapartida, o cantar é fixo, fala de um tempo mais próximo cronologicamente, dos problemas com a Igreja e com o poder público, das bizarrias; a guarda se movimenta no ritmo do Dobrado, abre e limpa os caminhos, executando uma dança 
que mimetiza o movimento do pilão, vertical, indo para o alto e voltando à terra como se a quisesse penetrar, com latas de chumbo (gungas) amarradas nos pés.

Como vemos em "Os Arturos dançam por dentro", a vida de devoção explicitada nos versos "Os santos pedem um corpo[...]/ O Arturo oferece a vida" (PEREIRA, 2003, p.58), é feita da reza em forma de canto, do corpo construindo o bailado da representação dos movimentos das guardas: o Moçambique fere a terra como um pilão visto que este é o modo como se desloca na Festa de Nossa Senhora do Rosário, enquanto o Congo mimetiza o movimento de vai-vem de um barco. Durante os festejos, as guardas tocam simultaneamente, mas com andamentos diferentes, criando uma aura musical que delimita o espaço sagrado de cada guarda (LUCAS, 2002, p.72). Outra das representações feitas é a história natalina dos Três Reis Magos:

O Bastião: Trouxe um par de enigmas e uma dança de bastões. Agora não sei de nada o frio, contudo, é maior.

O Friage: A caminho os guardas moeram a chuva encarangou: trago os dedos e a tremedura do corpo que espera.

O Velho: Quando vi sereno nasci com os ossos perfumados. A vida os foi quebrando trago as mãos e as sobras.

(PEREIRA, 2003, p.89)

Reproduzindo a peregrinação dos Reis Magos em busca do Messias que iria nascer, a Folia de Reis, realizada no período natalino, desfila em cortejo acompanhada de palhaços mascarados representando os soldados 
de Herodes ou o próprio demônio e, por serem um forte signo do mal, são impedidos de estar à frente do cortejo, de tocar a bandeira da Folia ou se aproximarem do presépio. Por outro lado, no Reisado transmitido por Arthur Camilo a seus filhos, os palhaços assumem papel de grande importância: são eles a representação dos reis Baltazar, Gaspar e Melchior, um deles inclusive carregando a bandeira sagrada. A história resgatada pelo primeiro dos Arturos narra que, enquanto fugiam de Herodes, Gaspar e Melchior tiveram vergonha da companhia de Baltazar, o rei negro; dispostos a seguirem sozinhos, partiram da estalagem em que se encontravam antes do despertar do terceiro rei que, percebendo a ausência dos companheiros, orou a Deus pedindo orientação; a estrela o guiou até Belém e, recebido pelo Deus-menino, foi abençoado com alegria e juventude: é ele Bastião, quem mais pula e brinca na Folia. Os outros dois sofreram no caminho e tardaram a chegar - Melchior, trêmulo de frio é conhecido como Friage, que se chacoalha e gagueja por não ter escolhido a humildade e a alegria; Gaspar, o Véio, é o depreciamento de quem segue o percurso mais longo para se chegar à Verdade.

Uma das festas mais recentes, a de Libertação, comemorada em 13 de maio, obedece a uma sequência lógica: um cortejo de escravos acorrentados recria a vida dos antepassados antes da libertação; mais do que esta rememoração, a presença dos negros e das correntes dá ao momento mais força, e quando se veem livres das correntes, os libertos gritam e festejam. Em seguida se dirigem para a igreja que, de portas fechadas, demonstra um momento em que não podiam adentrar nos templos dos brancos: diante da lembrança da proibição cantam seu lamento até que, findo, o capitão pede ao padre que abra a porta para que possam entrar; os reis negros sentam-se diante do altar e recebem, no ofertório, coroas, bastões e espadas, símbolos de seu poder. As guardas, de indumentária festiva, canta durante a celebração (PEREIRA; 
GOMES; PEREIRA, 1990, p.78). A importância da reencenação dentro da comunidade é uma forma de adentrar no tempo sagrado, como vemos no seguinte trecho:

à medida que o homem experimenta o mito através dos ritos, ele deixa o tempo cronológico, profano, e penetra no tempo sagrado, que é simultaneamente primordial e recuperável a qualquer momento e para sempre. A reencenação dos mitos através dos ritos permite que 0 tempo individual seja unido ao tempo cósmico (RIBEIRO; FRIANÇA apud LUCAS, 2002, p.70).

As celebrações internas dos Arturos, como as festas de aniversário, com os aniversariantes do mês comemorando juntos numa única festa, na casa do pai, onde também são celebrados os casamentos, com música moderna na parte da frente da casa e Batuque nos fundos. Quando os músicos da frente vão embora, a roda de tambor se abre para jovens e crianças. A coreografia executada na roda tem elementos comuns a todos, como palmas, giros, sapateios, encontro de ombros ou mãos, mas há também movimentos que diferenciam os dançarinos já que, enquanto os gestos femininos são mais curtos, de faceirice derramada, os gestos masculinos, por sua vez, são mais livres no cerco que fazem ao corpo feminino, os ombros se tocando e o casal girando. Nos domingos comuns, a festa se divide com partidas de futebol entre as guardas ou entre os jovens e os velhos, ou ainda a disputa pela faixa de "Rei do Truco dos Arturos", todos estes elementos que mantêm o grupo unido em convivência e festejo.

A festa do João do Mato, um rito para destruir o capim e purificar as terras, expulsando o medo, desenvolve-se da seguinte forma: em mutirão, os capinadores vão ceifando o mato do chão enquanto cantam as alegrias e os lamentos da vida; quando se aproximam do fim surge o João 
do Mato, coberto de folhas, expurgado do lugar capinado, em fuga enquanto passa sob o som das enxadas erguidas, batendo umas nas outras enquanto se ouve a cantiga de expulsão: "Entre as árvores o medo" (PEREIRA, 2003, p.78), medo do João do Mato, medo do mal vencer o bem. Como representa a erva daninha que pode se espalhar e colocar em risco a plantação, ou atrair pragas, deve-se eliminar o ser antes do Natal, visto que a capina do milho ocorre em dezembro, criando uma rivalidade entre a criatura ameaçadora e o Jesus-menino. Mas não se pode descuidar, é preciso repetir anualmente a celebração, pois o tempo é cíclico: a capina é feita, segue-se o plantio e a colheita, depois novamente o mato e nova capina é necessária. Tenta-se controlar o mal, a morte (pela renovação) e o tempo através do ritual, que sempre retorna.

Em artigo de 2010, Pereira aponta que a apropriação mais comum de elementos do universo afro na Literatura Brasileira é feita a partir da matriz iorubá, (embora tenha sofrido rejeições face ao modelo literário vigente) grande diante dos poucos empréstimos tomados à matriz banto; faz-se necessário, portanto, um espaço maior para a explicação do que são chamados cantopoemas e sua importância na discussão da literatura brasileira. A nomenclatura utilizada por Pereira difere daquela empregada pelos fiéis: enquanto os devotos da Senhora do Rosário seu autonomeiam como "pretinhos do Rosário", "vassauli" ou "marujo", a iniciativa de escolher um nome próprio tem como intuito tentar estabelecer um diálogo com as representações universais do sujeito criador, daí a opção por "cantopoemas" para se referir aos textos e "cantopoetas" para nomear os seus produtores. Identificados nas celebrações do Candombe, os cantopoemas utilizam como suporte a linguagem oral e a escritura, constituem-se de elementos formais tais como versos livres, com grande variação no que se refere aos esquemas de rimas e estrofes, improvisação, repetição de fórmulas, expressão através do canto, da 
coreografia e da dramatização. É possível distinguir dois tipos de cantopoemas: os menos sincréticos, nos quais são mapeados menor quantidade de elementos católicos e os mais sincréticos, exemplificados pelos orikis do Candomblé e cantos de Xangô; no caso dos bantocatólicos, que carregam elementos do catolicismo, candomblé e kardecismo, as principais manifestações são o jongo, os cantos do Congado e dos vissugos. A temática dos cantos pode variar, desde a viagem da África, o cativeiro no Brasil, as resistências religiosa e quilombola, a Abolição da escravatura, as relações com os ancestrais, até a metalinguagem e os conflitos ideológicos, como nos exemplos abaixo, complementares:

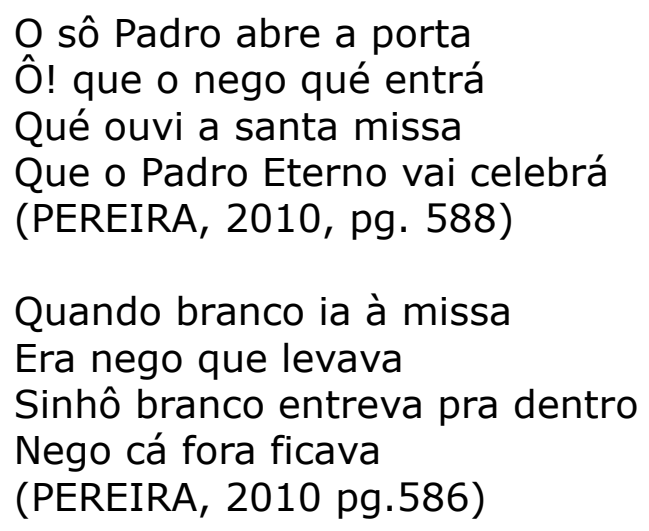

A argumentação de Edimilson de Almeida para inserir os cantopoemas (aqui exemplificados por aqueles mantidos pelos Arturos) no contexto literário brasileiro, cujas técnicas e visões de mundo diferem da literatura escrita, pauta-se na comparação dos cantopoetas com outros performers, como os griots africanos, o songman australiano, os troubadours e jongleurs medievais: todos compartilham o fato de serem sujeitos multimeios, alguns com afirmação de seus contextos sócioculturais e, no caso específico dos performers mineiros, preocupações estéticas e lúdicas e o sincretismo religioso. Afirma o autor: 
- estatuto de textualidade rejeitada atribuído ao legado banto-católico não é suficiente para afirmar que ele deixou de ser mantido e recriado nas comunidades de devotos espraiadas pelas periferias urbanas e regiões do interior do país. Essa textualidade - apesar de não chegar aos currículos das instituições de ensino ou aos meios de comunicação - vem sendo criada e recriada desde o período colonial; sua vitalidade é justificada na medida em que os devotos a tomam como um medium para relacionar-se com o mundo a fim de compreendê-lo e de atribuir-lhe sentidos. [...] No que diz respeito à literatura, a noção de poema ensinada nas escolas e universidade não apreende a contento as criações dos devotos, cuja representação textual, mesclada ao canto e à coreografia, é exibida através de um registro que não corresponde à língua padrão e aos meios de difusão legitimados. Porém, quando os circuitos acadêmicos se deixam afetar pela sensibilidade mais do que pela intransigência dos métodos, articulam-se argumentos para legitimar as textualidades não canonizadas. (PEREIRA, 2003, pg.10)

O ponto que defende Pereira é que, se continuarem sendo tratados como documentos, que circulam basicamente nos contextos da antropologia e ciências sociais, os cantopoemas permanecerão rejeitados no âmbito literário, caso que caracteriza como de situação de exílio, ou de uma "poética subterrânea" (expressão tomada de Antônio Risério), ou ainda de literatura silenciosa, termo cunhado por Patrick Chamoiseau e Raphaël Confiant, significando tanto "a textualidade de grupos marginalizados em conflito com a literatura legitimada" quanto que "a alusão ao silêncio compreendida como um pretexto para garantir a tessitura de um discurso complexo e criativo." (PEREIRA, 2003, pg.10).

Como o trabalho desenvolvido por Pereira se mostra bastante sofisticado para se restringir ao âmbito teórico, em sua obra poética podemos colher exemplos da inserção de caracteres de uma estética banto-católica na produção poética brasileira. Em "Guarda de 
Moçambique", lemos:

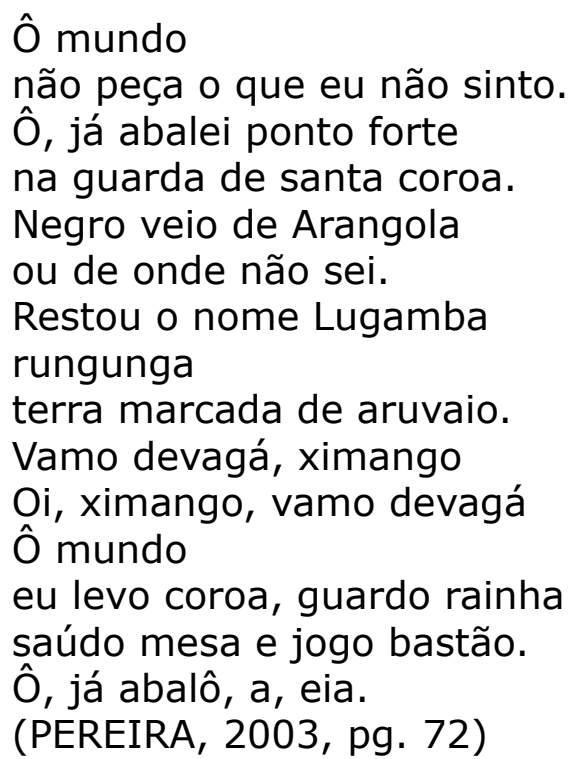

No cortejo da Guarda, vemos a presença do sincretismo representado pela "guarda de santa coroa" (de Nossa Senhora do Rosário) e o acréscimo de um possível lugar de origem ("Negro veio de Arangola/ ou de onde não sei."). Ao lado do corpo do poema, vemos uma indicação para que o ritmo seja desacelerado ("Vamo devagá, ximango"): dentro das celebrações, alguns cantos são mais conhecidos ou apreciados e, quando o cantopoeta entoa o canto de um antepassado, o discurso estabelecido por um outro, é importante que as improvisações feitas, como no poema de Edimilson Pereira, seja de acréscimos de gestos, comentários pessoais ou orientações, não impeçam a identificação do cantopoema original, não abafem a voz do criador original do texto. 0 capitão que bem conduz o cortejo sabe fazer com que as duas vozes coexistam. 


\section{4. "I'M ALWAYS LIKE A TIGER, I'M READY TO JUMP"}

\section{1 - A Ira}

Embora a estrutura deste trabalho siga uma determinada convenção acadêmica (iniciei o texto da tese propriamente dito com um capítulo teórico para demonstrar nossa compreensão de um dos caminhos de abordagem possíveis), acredito que um dos cernes do trabalho deveria estar na leitura dos poemas do autor. Mesmo tendo produzido pesquisas antropológicas, publicado trabalhos de crítica, escrito livros infantis, a poesia foi o tecido que mais nos interessou desde o início e que acreditamos ser o maior fornecedor de senhas para os constructos textuais de Edimilson Pereira. Cabe neste momento, portanto, atentar um pouco mais para essas senhas.

Com o mapeamento do capítulo anterior, a partir daqui me deterei à leitura de algumas temáticas encontradas na obra poética. No trecho elaborado, optei por uma leitura que abordasse os elementos estilísticos encontrados nos poemas nos quais se percebem as manifestações musicais, passíveis que são de uma análise na qual se depreende elementos identitários e de manutenção cultural, e os pontos nos quais eles dialogam mais fortemente.

Em Nota Inicial presente em cada reunião poética, o poeta justifica a organização não-cronológica escolhida para os livros por preferir "que os textos conversassem entre si", e segue dizendo que "bem verdade, os livros poderiam ser agrupados de outras maneiras, além desta em que julguei reconhecer familiaridades de tema e estilo entre os textos. Mas, 
como tudo é uma questão de ritmos, o leitor, certamente, verá aqui outros bailes." (PEREIRA, 2002, p.15). As primeiras reuniões poéticas de Edimilson de Almeida Pereira reúnem livros escritos e publicados em momentos diferentes dos anos da carreira do poeta, mas agrupados sob o mesmo "pacto": ao reorganizar os trabalhos, Pereira optou por um arranjo temático. Partindo da justificativa do autor e aproveitando a brecha por ele oferecida, optamos por uma análise que contemple nesse baile os pares que executam a coreografia executada pelo poeta, procurando mapear alguns movimentos presentes nesta obra que ecoam também em outros pontos da festa construída por Pereira, como os elementos da cultura popular e a presença afrodescendente nas produções musicais.

Determinados elementos se repetem em todos os livros de Pereira. Um dos mais impactantes é o grito, le cri: inicialmente pode ser tomado apenas como sonoro, como um início, uma abertura a outros gritos, musicais, corporais, caminhos, mas com atenção percebe-se a música como forma de transportar esse grito; grito transportado pelo corpo, que acaba sendo veículo destacado pela mensagem que carrega. Para Glissant, presente em uma das epígrafes de Edimilson, os lugares comuns precedem à linguagem: há o momento de voltar ao grito, ao signo.

Outro índice é a ira, a luta, a peleja que sempre rondam o poema, seja na voz de Bessie Smith ("sou uma fábrica/ sou uma operária/ tenho a necessária raiva para viver"), da ira retrabalhada como combustível para impulsionar a vida e não destruí-la, a peleja no campinho (bater pelada); há também a raiva estranha que se sabe enorme, mas parece difícil de ser definida: o oceano preso na gente, a hidra, o animal domesticado que ataca, existe uma força que anima os sujeitos e os faz sobreviver alertas, lutando contra o esquecimento. Da ira partimos para o cabelo, um dos mais recorrentes, que serve para encantamentos, ou afirmação 
identitária; os elementos de origem africana ou usados em celebrações do congo e do reisado estão também presentes, a esfera, o movimento (signos de Exu), a pele ("varanda com vistas para o incerto") que é radar, cilada, o ato de 'cerzir um país com várias linhas', a alegria como disfarce, bordar para tramar insurreições; o corpo do outro, a umidade amorosa, o arco do mundo.

Durante o período colonial nas Américas, sobretudo em Santo Domingo, cimarrón foi o termo usado para se referir aos negros ou indígenas que, escravizados, se rebelaram da subjugação do regime ao fugir para regiões nas quais não conseguiam ser alcançados, como o alto dos morros, daí umas das possíveis origens do nome, considerando que se reuniam no "cimo" dos morros. Como há registro da utilização do termo antes de 1530 nomeando os índios alzados, a origem permanece incerta. Do nome cimarrón vem a prática da cimarronaje, a resistência em si, refugiando-se juntos em lugares que permitiam "subsistir en su propio ambiente, cultivar las costumbres recientemente aprendidas junto a las antiguas creencias religiosas, para luego unirse después a los movimientos de cambio y justicia em busca de la igualdad.", como explica William Luis no prefácio de outra obra do poeta aqui analisado, Signo cimarrón, (2005, p.09), livro inteiramente escrito em espanhol, do qual utilizaremos algumas passagens ao iniciar a leitura de Zeosório....

A escolha do cimarrón como importante elemento constitutivo do conjunto de poemas pode ser exemplificada pelos versos de "Signo": "El signo es cimarrón, el texto/ una cimarronada". É patente o motivo da recuperação desse personagem da colonização europeia nas Américas se entendermos o poema como espaço de reflexão acerca dos cimarrones e seus descendentes, mas também como o próprio fazer poético, com escolhas e posicionamentos tão claros, ser visto como forma de cimarronaje possível no âmbito artístico para relembrar aqueles que não 
se curvaram ante as correntes físicas e psíquicas utilizadas pelo colonialismo e continuadas pelas políticas de desiguladade racial pós libertação dos escravos, como aparece em "Indicios": "Los textos/ de la memoria esperan lectores,/ el desafío es escoger la frase/ que nos presenta unos a los outros" ["Os textos/ da memória esperam leitores,/ o desafio é escolher a frase/ que nos representa uns aos outros"] (2005, 23).

O que demonstram ter nos poemas: a Ira, representada pelo grito que cresce depressa - e permanece, uma vez que vive nos séculos. Esse grito é recorrente em outros poemas e também no Cahier d'un retour au pays natal de Aimé Césaire, com o qual Edimilson Pereira dialoga fortemente em "Caderno de retorno" (perguntar para MJ: o que eu faço, reescrevo parte das coisas que fiz na dissertação de mestrado já que não publiquei?). O grito, le cri: inicialmente pode ser tomado apenas como sonoro, como um início, uma abertura a outros gritos, musicais, corporais, caminhos. [v.Césaire - "cette foule qui ne sait pas faire foule"].

\section{2 - O Ritmo}

Utilizar a palavra é um modo de mostrar que foi possível sobreviver a algumas restrições como a do aprendizado da escrita, símbolo da alta cultura no ocidente, proibida aos negros escravizados no Sul dos Estados Unidos, por exemplo: infringir tal norma era passível de punição; daí a importância da oralidade para o desenvolvimento da música negra na diáspora, servindo, combinado à dança, como forma de comunicação. 
Mesmo a expressão através da música não era permitida em todas as suas possibilidades, visto que o uso de tambores era proibido em algumas regiões dos Estados Unidos durante o período de escravidão dos negros, para impedir que se comunicasse; o uso de temática amorosa em alguns dos primeiros blues servia para, indiretamente, reclamar da exploração do patrão: o sujeito queixava-se de que a mulher não o tratava bem, tomava-Ihe o dinheiro, querendo referir ao chefe, conforme narra Willie King a Corey Harris em Feel like going home. EM O atlântico negro, Paul Gilroy ressalta que

O topos de indizibilidade produzido a partir das experiências dos escravos com o terror racial e reiteradamente representado em avaliações feitas no século XIX sobre a música escrava tem outras importantes implicações. Ele pode ser utilizado para contestar as concepções privilegiadas tanto da língua como da literatura enquanto formas dominantes de consciência humana. O poder e significado da música no âmbito do Atlântico negro têm crescido em proporção inversa ao limitado poder expressivo da língua. É importante lembrar que 0 acesso dos escravos à alfabetização era frequentemente negado sob pena de morte e apenas poucas oportunidades culturais eram oferecidas como sucedâneo para outras formas de autonomia individual negadas pela vida nas fazendas e nas senzalas. A música se torna vital no momento em que a indeterminação/polifonia linguística e semântica surgem em meio à prolongada batalha entre senhores e escravos. Esse conflito decididamente moderno foi resultado de circunstâncias em que a língua perdeu parte de seu referencial e de sua relação privilegiada com os conceitos. (GILROY, 2001, 160).

As referências musicais surgem a partir de nomes de músicos, instrumentos, ritmos, e se misturam muitas vezes às celebrações religiosas (os tambores do Candomblé, os pontos para os orixás), ao canto que facilita o trabalho (o João do Mato), à música que impede a dor de tomar conta do sujeito e paralisá-lo (como o blues que encurta as 
férias no inferno de Mama Bessie), às notas que ferem (retiradas dos metais); uma coisa é certa: os ritmos são sempre aprendidos por experiência, não por teorias ou conceituações, são parte da vivência e se confundem com o fazer poético.

Mas a música tem outras finalidades: cantar é uma prática contra o esquecimento. A tríade de poemas protagonizados por Joplin e Bessie Smith em "Carta de Janis a Bessie", "Carta de Bessie a Janis" e "Depois das cartas" demonstra isso: após a morte de Bessie Smith, possivelmente vítima de negligência médica, o túmulo permaneceu por anos sem lápide até que Janis Joplin, com alguns amigos, encomendou uma pedra com os dizeres "A maior cantora de blues que o mundo jamais deixará de ouvir": separadas por terem vivido momentos diferentes no mesmo país, os poemas promovem o diálogo entre as duas cantoras e funcionam como registro que luta contra o apagamento de vozes dissonantes.

Apesar da mistura e profusão de ritmos, é possível perceber os mais frequentes e quando estes aparecem: em Zeosório blues, a música fora do ambiente sagrado, mas não menos séria ou comercializável, por ser também vida, é preciso seriedade no trato, afinal "um compositor não samba para turistas" (PEREIRA, 2002, p.41). No livro, a música dos terreiros e velórios traz a força que inunda os sujeitos, faz com que dancem nos clubes, viagem nas ondas vindas do rádio, ouçam os lamantins, o "canto" comparado ao das sereias, como uma lamentação (Colombo anotou numa caderneta de expedição a presença de três sereias, entendidas hoje como os animais citados), cantem pelo não apagamento da memória - como faz Joplin inserindo no próprio canto as particularidades das cantoras de blues. Aponta-se em "é Dixie a canção/ que sabemos" (2002, p.13), para a canção "Dixie" ou "I Wish I Was in Dixie".

Ainda sobre o ritmo, a "Sociedade Lira Eletrônica Black Maria", 
entendida mais como grupo performático multimídia do que musical, criado por Ricardo Aleixo e Gil Amâncio (criador da Companhia Seraquê?), estabelecido em Belo Horizonte. Na explicação de Aleixo em entrevista a Ricardo Corona e publicada na revista Oroboro em 2005 ( n० 05, setembro), o poeta explica que "o nome homenageia Thomas Alva Edson, cujo estúdio tinha o nome de Black Maria, e, de tabela, ressalta a ideia de invenção presente no nosso projeto, que mistura poesia falada, cantada e cantofalada com música eletrônica e realização acústica, videopoemas e vídeo ao vivo, dança, performance, arte vestual, afrofuturismo, música concreta e o que pintar, sempre oscilando, propositalmente, entre hightech e low-tech". No livro de mesmo nome, o rádio traz o som que enche a casa.

Outro aspecto da expressão musical que aparece nos poemas de Pereira é o sagrado: os cantos do Candombe (cuja nomenclatura visaria, bizarria, gromenta, demanda, etc - varia de acordo com a função, seja brincar, desafiar, fazer a abertura, apaziguar) são marcações dentro das celebrações que se expandem para a poética de Pereira ("nada é feito sem ritmo"). Os pontos fazem a conexão entre o sagrado e o humano e abrem espaço para que os antepassados falem: às vezes, o desafio do cantopoeta é entoar o ponto de um antigo sem que as improvisações abafem a voz do antepassado.

A legitimação do discurso oculto do samba é perceptível na comissão de frente com "os todos/cabelos/da vida", todos os tipos/condições raciais/de vida; há sempre um ensinamento camuflado, um ocultamento, uma dança que esconde outra significação, talvez a luta, a ira que ronda por vezes os poemas.

As manifestações musicais, religiosas e de construção identitária são indissociáveis neste fazer poético, mas o conflito está presente: nas demandas do Candombe, no conflito com a religião oficial ("a culpa por 
não amar o deus imposto" - o substantivo deus está sempre em minúsculas), no sincretismo que permite a sobrevivência dos deuses antigos no exílio dos antepassados, com Exu se misturando ao santo católico (Santo Antônio dos Crioulos); há também as benesses advindas de Nossa Senhora do Rosário, a Grande Mãe tirada das águas (a lenda da Senhora do Rosário leva à adoção da santa pelos órfãos da África), um dos motivos encontrados pelos Arturos para continuar existindo na fé que se faz festa: durante todo o ano, rezar e dançar constituem a linguagem religiosa, o signo vital. A recriação ou fortalecimento dos laços interpessoais praticadas por Arthur Camilo e seus descendentes é ao mesmo tempo de caráter identitário e de união para resistência: a reificação do africano escravizado retirou-lhe a família, que é a principal raiz da árvore dos Arturos.

A temática das cartas aparece em mais de um livro de Edimilson Pereira, e pode ser encontrados principalmente em Zeosório Blues e Signo cimarrón. A leitura aqui sugerida será ao redor de três poemas, dois deles de Zeosório..., um de Dormundo. O primeiro destes poemas foi um dos estímulos para a elaboração da conversa entre compoēm os outros dois textos, uma correspondência fictícia entre as cantoras norte-americanas Janis Joplin e Bessie Smith, encontrados em Zeosório....

Edimilson Pereira conta, em entrevista de 2004 a Fabrício Marques, como surgiram os poemas de "Cartas": numa pesquisa sobre excelências (cantos fúnebres de intensidade dramática), a maior mágoa dos entrevistados era uma lápide sem inscrição, sinal de desaparecimento do morto da vida social. O poeta ressalta que o apagamento da memória de alguns mortos não se deve ao esquecimento natural, mas a um ato político, quando o morto incomodava de alguma forma o status quo. Se apagar um nome pode ser considerado um ato político, fazê-lo voltar à tona, fazer a voz ressurgir aos ouvidos dos vivos também é um ato 
político, forte sobretudo se aquele que é lembrado era conhecido por discordar do discurso vigente (MARQUES, 2004, p.97). Além da pesquisa sobre excelências, a existência de um poema anterior também foi importante para o surgimento desta conversa entre as duas cantoras, e na mesma entrevista Pereira afirma que

precisava dar uma resposta a um antigo poema, [...] onde
anotei: "Cartas adernam no espírito". Ao colocar Bessie e
Janis em contato, via lettera, não quis resolver apenas esse
meu impasse, resgatando a carta (e a comunicação) do
naufrágio, mas afirmar também a confiança de que a arte
ainda é capaz de nos colocar ante a nossa natureza de seres
que não se dobram e não se quebram. (MARQUES, 2004,
p.67)

O poema ao qual Edimilson se refere alerta sobre os perigos deste meio de comunicação:

CARTAS

O perigo está na carta.

Envie outra coisa, móvel e compassiva:

o bloco carnavalesco, a erva, exumação do saldo

que compõe e dissipa.

Cartas adernam no espírito.

E o recebimento é causa

que a cidade interdita contempla.

Somente em desafio a paixão perdo.

Outra dívida se impõe a carta.

O amor não compreende.

O contato não tem forma. 
O perigo está na carta.

(PEREIRA, 2003, p.57)

Janis Joplin, cantora estadunidense nascida em Port Arthur, começou a despontar no cenário musical nos anos 60, quando iniciou suas apresentações como vocalista da Big Brother and the Holding Company, de San Francisco. Tornou-se uma figura icônica na história do rock, muito pelo envolvimento com drogas e a morte causada por overdose de heroína, talvez mais lembrados do que suas performances musicais. A biografia Scars of sweet paradise, de Alice Echols, demonstra a dificuldade em se comportar de acordo com as expectativas familiares e sociais, especialmente no seu interesse por pintura e música:

Para o trabalho de uma adolescente presa no Golden Triangle [Texas, que inclui as cidades de Beaumont, Port Arthur e Orange], as pinturas de Janis são extraordinariamente fortes, mas sua paixão pela arte foi considerada como um déficit em Port Arthur, onde isto só fez com que ela parecesse mais peculiar aos jovens que não eram da sua turma. [...] "Ela era selvagem e estranha e incomum." (ECHOLS, 2000, p.20-1)

O trabalho artístico inicial de Janis foi a pintura, mas seu interesse por música foi alimentado paralelamente, durante a adolescência, com a dedicada escuta de música folk e antigos blues, e a tentativa de imitar as interpretações de Odetta, cantora afro-americana dos anos 1960, "the queen of folk music" [a rainha da música folk] (ECHOLS, 2000, p.21). Mas, quando decidiu se dedicar mais seriamente à música, sua atenção voltou-se para as cantoras de blues, como atestam amigas da época, Linda Gottfried e Jae Whitaker: "'She studied Leadbelly, Billie Holiday, Bessie Smith. On Sundays we'd go to various black churches and sit in the back and do gospel.' [...] Bessie Smith was her idol, though. 'She felt she 
was Bessie Smith reincarnated. She really did."' ["Ela estudou Leadbelly, Billie Holiday, Bessie Smith. Aos domingos íamos a várias igrejas negras e sentávamos na parte de trás e ouvíamos [música] gospel." [...] No entanto, Bessie Smith era sua ídola. "Ela sentia que era Bessie Smith reencarnada. Ela realmente sentia."] (ECHOLS, 2000, p.75). Com Bessie Smith, aliás, a relação pode ser estabelecida não apenas no que se refere à incorporação de elementos de interpretação musical, mas na identificação do túmulo de Smith: Joplin, junto a Juanita Green, teria sido responsável pela lápide feita nos anos 1970.

Enquanto ainda morava com a família em Port Arthur, a principal diversão noturna de Joplin e seus amigos era ir em busca de uma música mais autêntica nas cidades do entorno: "The gang's passion were folk, blues, and jazz, but they also spent many nights across the line in the Cajun town of Vinton, Louisiana, where Jim Langdon began getting gigs playing trombone in rock 'n roll bands." [A paixão da turma era folk, blues e jazz, mas eles também passaram várias noites do outro lado da linha na cidade Cajun de Vinton, Louisiana, onde Jim Langdon começou a fazer shows tocando trambone em bandas de rock.] (ECHOLS, 2000, p.22). Interessante notar a expressão "across the line", que serve para indicar a fronteira física entre os estados mas também um outro lado para a exploração musical, atentando para músicos que estavam à margem da sociedade americana dos anos 1960.

Mas para cantar o blues, para que a performance fosse verdadeira, era preciso mais do que dedicação e estudo, era preciso pagar o preço da carga emocional que a música implica, como contam o empresário e o músico que trabalharam com Joplin na época:

"Ela sentia que tinha que pagar o ônus para cantar blues. De alguma forma ela sentia que de não havia sofrido o 
bastante," diz Chet Helms [...]. Michael Pritchard, um guitarrista que tocou com Janis nesse período, diz: "Eu podia tocar blues tecnica mas não emocionalmente ou psicologicamente por causa de tudo que o blues implica." (ECHOLS, 2000, p.78)

\section{CARTAS}

\section{DE JANIS A BESSIE}

A gente não tem o que quer.

Queria ser de rua.

Usar filtros de ontem.

Não explicar as ranhuras.

Não importa falar

que amei.

Amor é a guinada.

O dia preferido não vem.

Olho fotos de infância

e sinto a angústia

de quem é feliz.

Queria ser a santa clara

dos demônios.

Espetar na memória

a agulha letal.

Mas não adianta

sofrer.

A rua continua lá.

O coração continua

como as marcas de pneus.

As coisas continuam

em quem passou por elas.

E nem dá para viajar

fora da eternidade.

A gente não tem o que quer.

(PEREIRA, 2002, p. 97) 
Os vinte e três versos são distribuídos por nove estrofes sem regularidade (1-3-3-4-4-2-3-4-1), com versos curtos e assertivos em sua maioria ("A gente não tem o que quer"; "Amor é a guinada", "Mas não adianta sofrer"). O poema não apresenta rimas marcadas, exceto talvez pela repetição do som [ua] de "rua", no segundo verso, em "ranhuras", no quarto verso. A sonoridade que aproxima estas duas palavras pode ajudar a entender a proximidade atemporal entre as interlocutoras: a conotação de "rua" como passagem pública, "via ladeada de casas", (indicada no Dicionário Priberam da Língua Portuguesa, 2013), traz, por extensão, o sentido de "habitantes de uma rua; a plebe" (Priberam, 2013); já o substantivo "ranhuras", definido como "entalhe feito na espessura de uma tábua ou de uma peça de ferro para nela se encaixar o ressalto ou dente de outra peça" (Priberam, 2013), indica o talhe feito não numa peça, mas numa pessoa, para permitir o encaixe de outra/ outro - outras pessoas, outros comportamentos. Os desejos expressados, "Queria ser de rua" e "Não explicar as ranhuras", indicam a tentativa de se inserir em um lugar exterior, não conectado a normas sociais rígidas, sem ter que justificar a existência das marcas presentes no eu-lírico. A rua, espaço dos que estão de algum modo excluídos e as ranhuras, marcas incisivas, abrem o poema de modo a deixar claro que o sujeito que fala não se encaixa em esquemas previstos.

O primeiro verso funciona como um refrão de abertura e encerramento. A afirmação feita no primeiro verso é repetida no último, não há mudança de desejo ou realidade no decorrer do poema: a assertividade dos versos corroboram o refrão.

A carta de Joplin é a primeira a aparecer considerando a paginação do livro em que foram publicadas, Zeosório Blues. Lemos a carta de Janis primeiro pela lógica de ter sido a cantora mais nova a ouvir a mais velha, pois quando Joplin nasceu Bessie havia falecido há quatorze anos. A forma 
de tratamento utilizada pela locutora Janis para se dirigir à interlocutora Bessie, no primeiro verso, "A gente", demonstra a identificação de Joplin em relação à sua interlocutora. Como destaca Nilce Sant'anna Martins, "As diferentes formas de tratamento correspondem a diferentes graus de intimidade/ distância e níveis de hierarquia social" (MARTINS, 2008, p.259). A escolha do informal "A gente" no lugar da primeira pessoal do plural, "Nós", é um sinal de proximidade entre as partes, como se compartilhassem a mesma situação. Neste caso específico, ambas foram cantoras que simultaneamente atraíram tanto elogios pelas performances quanto críticas pelos comportamentos não adequados aos seus papéis sociais de mulheres ou mulher negra, no caso de Smith.

No poema-carta de Bessie a Joplin vemos a presença da morte, do sangue, da falência e da raiva, mas uma raiva necessária, sem a qual não se vive:

\section{DE BESSIE A JANIS}

Amar a música leva ao amor dos músicos.

Precisei deles para ver como os felinos são tranquilos.

Precisei deles quando as férias no inferno duravam.

Outro remédio é tomar o ônibus.

Dizer ao vizinho morrer não é elegante.

Ninguém lê as tardes. Não gostam do carmim nas flores. 
O sangue sai uma vez

de nossa vida.

É a música ligada.

Isso não é morrer.

É falir como as fábricas

que deixam raiva

nos operários.

Eu sou uma fábrica.

Eu sou uma operária.

Sinto a necessária

raiva para viver.

(PEREIRA, 2002, p.113)

Chamada de "imperatriz do blues", Bessie Smith é considerada uma das maiores cantoras do ritmo, uma das primeiras intérpretes negras a alcançar sucesso, com grande capacidade de improvisação. Sua morte foi causada pela falta de atendimento na frente de um hospital que não atendia negros, após um acidente de carro. Eric Hobsbawn comenta, em História Social do Jazz, que sentimentalismo e autopiedade não fazem parte do blues: ou se vive a vida como ela e ou se morre: "Eles [reler; eles quem?] riem e choram porque são humanos, mas sabem que isso não adianta. Nada adianta, a menos que eles queiram se ajudar. Pois raramente se fala do céu, uma canção puramente secular, e também não há Deus, embora, algumas vezes, no Blue Spirit Blues, de Bessie Smith, haja inferno." (2010, p.206). [pesquisar]

$\mathrm{Na}$ "Carta de Bessie a Janis" os atores não parecem ter seus papéis tão definidos. Os músicos podem ser facilmente reconhecidos na função de destinadores, sujeitos do fazer que dotam o sujeito (eu-lírico) da capacidade de percepção: o eu-lírico adquire uma competência ("ver como os felinos/ são tranquilos"), e é ainda auxiliado pelos destinadores "quando as férias no inferno/ duravam". Reconhecemos o sujeito e seus destinadores iniciais, mas o verso "É a música ligada" parece desdobrar-se 
nos papéis de destinador e antissujeito: o sangue que sai, mas que não provoca a morte, indica uma gradação que começa com "falir" e é menor que "morrer", daí a impressão inicial de se tratar de um antissujeito, visto que algo que faz sangrar a vida não é visto como benéfico. Mas nas duas penúltimas estrofes percebemos que é necessária a existência do provável antissujeito "música ligada" para que o sujeito sinta raiva, necessária para viver, e assim adquira competências; o enunciado de estado encontrado nos versos "Eu sou uma fábrica./ Eu sou uma operária." poderia então se concretizar, sendo a presença semiótica de realização indicada pelo verbo "ser".

Eric Hobsbawn descreve as grandes cantoras de blues, como "Leoas, embora às vezes feridas ou na defensiva (Bessie Smith não se autodenominou 'um tigre pronto para dar o bote'?)" (1998, p.402); nos dois poemas percebemos elementos lexicais em torno tanto da imagem das leoas (felinos) quanto referente a uma posição de defesa alimentada pela possibilidade de ataque iminente, como as férias no inferno, a raiva que cresce nos operários, a angústia que quem é feliz; lidos em conjunto, é como se a sintaxe narrativa se nutrisse de si mesma, com os actantes desempenhando funções diferentes para garantir a continuidade.

A construção poética tenta repetir os gestos melódicos de Smith, que pode ter escapado do inferno no poema, mas carrega consigo a raiva, e a cimarronagem de Joplin ao encomendar a lápide, que escolhe continuar o canto iniciado anteriormente por Bessie. Finalizando com as palavas de Edimilson Pereira, "a experiência de cantar na dor não se resume a uma frase feita, é algo mais profundo, que incomoda quem oprime e alimenta quem está em desespero". Já não se trata só do canto, mas de um discurso e de uma atitude, coisas que nos dão a esperança de ver o homem mesmo onde ele parece ter sucumbido. A opção por uma leitura conjunta dos três poemas foi feita para melhor observar a conversa 
proposta por eles que, mesmo separada pela impossibilidade de comunicação empírica - visto que a distância entre a morte de uma e o nascimento da outra é de mais de dez anos - não impede uma comunicação no âmbito poético.

Mesmo a organização das "Cartas" nos dá indícios de como ocorre a 'conversa' poético-musical: a carta de Janis, que aparece primeiro no livro Veludo azul, terceiro dentro da obra poética 1 , é a cantora que cronologiamente apareceu depois, mas surge antes no livro porque é aquela que lembra, que faz referência ao universo daquela que a influenciou. Janis aparece em clara incompletude, podendo o eu-lírico ser caracterizado num enunciado elementar de estado, em disjunção com o objeto.

Publicado no ano de 1998, Águas de contendas traz, logo no título, um dos muitos caminhos possíveis para se percorrer o livro: a ideia de luta, de disputa por algo em momentos e espaços variados. Tal como Rebojo, publicado em 1995, a movimentação das águas revela a existência de elementos em conflito constante. O poema de abertura, "Os Dias", lemos uma quase epígrafe: "Quem escreveu vem à janela,/ o que passou outra vez passa." (PEREIRA, 2003, p.127); os versos indicam o retorno de temas e cenários que o poeta, "quem escreveu", observa mas também ajuda a nomear, o que é perceptível no poema seguinte:

\section{SANTO ANTÔNIO DOS CRIOULOS}

Há palavras reais.

Inútil escrever sem elas.

A poesia entre cãs e bichos

é também palavra.

Mas o texto captura é o rastro

de carros indo, sem os bois.

A poesia comparece

para nomear o mundo.

(PEREIRA, 2003, p.113) 
Neste poema, ressalto $\mathrm{O}$ caráter nomeador: "A poesia comparece/para nomear o mundo", a representação do verso como o rastro que é capturado pelo texto, o carro de boi sem os animais, num exercício filológico de retomada da origem da palavra: versum, em latim, é o desenho que se forma no chão depois do campo ser arado para o plantio. Mesmo com o forte caráter meta poético, é possível identificar índices que podem ser mapeados no decorrer do livro: Santo Antônio, padroeiro de Juiz de Fora, cidade natal do poeta, que aparecerá retratada em diversos poemas, é o santo associado a Exu no Candomblé. Exu, cujo nome em iorubá significa esfera, é conhecido por ser o orixá do movimento, é o guardião do terreiro, aquele que primeiro deve ser saudado; embora reaja positivamente quando bem tratado, Exu é mais conhecido por suas reações quando estão em falta com ele, provocando disputas, montando armadilhas, criando contendas. Mesmo que o poema seja intitulado com o nome de um santo e que muitos elementos do catolicismo se apresentem no decorrer do livro, não custa nada saudar Exu e garantir a tranquilidade dos trabalhos, acrescentando ao nome do padroeiro dos pobres e dos noivos o complemento "dos Crioulos"11.

Retomando a bibliografia teórica sobre o poema, deparamo-nos com a tentativa de Octavio Paz em diferenciar prosa e verso em $O$ arco e a lira. O teórico mexicano classifica o poema "como um círculo ou uma esfera algo que se fecha sobre si mesmo, universo autossuficiente no qual o fim é também o princípio de volta, se repete e se recria" (PAZ, 1982, p.15). A definição ajuda a retomar a imagem de Exu, mas o caráter autossuficiente do universo poético não o impede de dialogar tão fortemente com outras formas textuais a ponto de quase se confundir com elas.

\footnotetext{
11 Uma leitura mais detalhada deste poema foi feita por Maria José BARBOSA e pode ser encontrada em: BARBOSA, Maria José Somerlate. Recitação da passagem. Belo Horizonte: 2010, p.80.
} 
Ô Lapassi \& Outros Ritmos de Ouvido apresenta, em seu início, uma série de poemas, numerados de 1 a 40 . Nos primeiros poemas, os versos surgem esparsos, distantes uns dos outros, distribuídos em diversas estrofes; depois vão se aproximando, o número de estrofes diminui e há mais versos nelas. Ao final desses 40 poemas, que nos guiam como pequenos trechos de um caminho, chegamos aos poemas-cidades que completam o livro.

Apesar do corpus inicial de análise deste texto serem os treze poemas designados com nomes de cidade, para chegar a eles precisamos, mesmo que brevemente, caminhar pelos poemas precedentes, que iniciam o trajeto. Nestes, é possível ver a música como forma de transportar o grito de que fala Oswaldo de Camargo na epígrafe "Súbito o grito - ô - cresceu depressa/ ante as portas do ouvido, um "ô" tão longo/ para viver nos séculos" (PEREIRA, 2002, pg.13). Ela aparece por seus instrumentos, seja a clarineta de treze chaves de Dimundi, o irmão caçula, como vemos no poema 5 (PEREIRA, 2002, p. 21), ou o acordeon Schandall do cego no poema 21 ( $p .29$ ); temos também os homens e mulheres ligados à música e à dança: o trompetista do poema 3 (p. 20), a comissão de frente, a porta-bandeira, o mestressala, nos poemas 14 ( $p$. 25), 23 (p. 30) e 33 (PEREIRA, 2002, p. 34), respectivamente.

A multiplicidade musical está presente não apenas em seus signos, mas também em seus ritmos: temos jazz, blues, samba, dobrado, ritmos presentes em um baile que parece aceitar qualquer harmonia, até mesmo as que, à primeira vista, apresentam-se dissonantes, como pensaria um leitor distraído que se esquecesse de acessar a informação de que o jazz, música hoje tida como tão sofisticada, originou-se do blues, que por sua vez nasceu dos cantos de trabalho nas plantações do sul dos Estados Unidos e dos spirituals negros. Nasceu de construções musicais populares, como o samba e o dobrado. O falar coloquial é perceptível, além do título, 
também no decorrer dos poemas, como no de número 7, em que "mestre/ Jacaré e o com viver/ de lua" transforma-se, alguns versos depois, em "mestre alua Gincaré" (PEREIRA, 2002, p. 22); o verbo 'aluar', em português do Brasil, é considerado uma palavra de uso informal, e indica que o sujeito enlouqueceu pela influência da lua (a preposição latina $a$, ad indica movimento para aproximação ou ainda transformação - no caso, a transformação do mestre Jacaré em Gincaré); no poema 10, "na banda/ o ritmo da cidade/ quiéssa é maravilhosa" (idem, ibidem, p. 23), vemos a junção gráfica dos pronomes 'que' e 'essa' em uma única palavra, mantendo a junção da fala, sem romper com o ritmo.

O que aqui chamarei de cidades não se refere necessariamente à sede de um município, mas a espaços urbanos que compreendem (além das cidades propriamente ditas) bairros, distritos ou townships sulafricanos. Embora as cidades que dão nome aos poemas existam de verdade, os versos que compõem as "ruas feitas de textos" refletem imagens cuja existência não podemos averiguar geográfica ou materialmente. Os poemas podem ser fruto do olhar de alguém sobre as cidades reais (ou suas histórias), acrescentado das subjetividades e particularidades captadas por ele.

Em texto de 1994, Renato Cordeiro Gomes analisa As cidades invisíveis, de Ítalo Calvino; apesar de se referir especificamente às cidades presentes no livro do escritor italiano, o texto de Cordeiro Gomes nos auxilia na leitura das cidades de Edimilson de Almeida Pereira visto que, segundo ele: $O$ texto é o relato sensível das formas de ver a cidade; não enquanto mera descrição física, mas como cidade simbólica, que cruza lugar e metáfora, produzindo uma cartografia dinâmica, tensão entre racionalidade geométrica e emaranhado de existências humanas. Essa cidade torna-se um labirinto de ruas feitas de textos, essa rede de significados móveis, que dificulta a sua legibilidade (GOMES, 1994, p.24). 
A cidade simbólica, construída pelo olhar do observador/leitor, mesmo quando se oferece organizada racionalmente, deixa brechas para que o homem a reconstrua simbolicamente e veja nela outros trajetos que não os indicados explicitamente, criando assim outros mapas, como veremos posteriormente, com as cidades dos poemas de Pereira, que se ligam de modo não-linear. O primeiro poema-cidade presente em Ô Lapassi..., 'Oyo', remete-nos ao Império de Oyo, estado iorubá de maior importância política em meados do século XVII. Fundado antes de 1400, tendo como capital Oyo Ilê, dominou estados iorubás mais fracos e o reino fon do Daomé. De 1656 a 1730, o grupo hoje denominado iorubá, termo utilizado tanto para designar o grupo lingüístico ou cultural, ocupava a região então nomeada Ulkumy. A partir de 1726 esse nome dá lugar a 'Ayo' ou 'Eyo', ambos designando Oyó (VERGER, 2002). Com uma revolta em 1796, o império começou a se desfazer. Eis o poema, seguido de "Salvador", o décimo poema:

OYO

o mundo e sua carne sob os olhos divinos

Em Oyo a manhã e uma árvore ajuntam os homens quando nenhuma lei do mundo decifra em suas faces a religião do outro. À caça nem de governos nem de assuntos a manhã em Oyo se deposita sobre o chão: com ou sem nenhum receio os companheiros as plantas de seus pés ouvindo como se falassem entre si os deuses. Em Oyo as nuvens. (PEREIRA, 2002, p.37)

\section{SALVADOR}

sob os olhos divinos o mundo e sua carne se arranham

Em Salvador a manhã e uma oferenda ajuntam 
os homens quando toda lei do mundo oculta em cartões postais o esqueleto do outro. Com a manhã o mar se oferece ao chão e o pensar dos muitos cresce cidade adentro as letras de seus olhos gravando como se lessem a verdade dos deuses. Em Salvador o tempo. (PEREIRA, 2002, p.41)

É possível observar no último poema, "Nova Orleans", uma idéia que auxilia na compreensão de "Oyo": no subtítulo de "Nova Orleans", "como um canto transpõe a hipocrisia", o verbo transpor, além do significado primeiro de movimentar para outro lugar, indica também a ação de passar para outro tom uma melodia ou um trecho musical. Seguindo a idéia da mudança de tom, no poema-cidade "Salvador", a transposição acontece se partirmos da leitura conjunta do poema "Oyo". Essas cidades aparecem simétricas, com a estrutura frásica similar, o compartilhamento de palavras e imagens, embora não sejam idênticas. Em texto de 1994, Ricardo Cordeiro Gomes fala sobre uma das cidades de As cidades invisíveis, de Ítalo Calvino:

Apreender, assim, as cidades é detectar o fio condutor de seu discurso, o seu código interno. Descrever e rearticular esse fio é a tentativa de ler a cidade, que parece um quebracabeça ilegível, semelhante ao sonho. Nesta ótica, a duplicidade é o princípio estruturante das cidades invisíveis: cada cidade se divide em duas. Há duas maneiras de ler a cidade, embora não simétricas [...]. As duas cidades gêmeas não são iguais, porque nada do que acontece em Valdrada é simétrico. O jogo aponta, desta maneira, para a disjunção entre a cidade e o discurso que a descreve. (GOMES, 1994, p. 50)

O compartilhamento de palavras entre os poemas, como a manhã que está presente no $1^{0}$ verso de ambos; ou ainda como a manhã em "Oyo", que se deposita sobre o chão, e o mar que se oferece ao chão em "Salvador" - chegando a ser possível ler no segundo poema uma citação 
do primeiro: "Com a manhã o mar se oferece ao chão", com 'a manhã referindo-se a "a manhã em Oyo se deposita sobre o chão". Enquanto em "Oyo" a religião dos homens não é decifrada, em "Salvador" a oferenda se apresenta logo no primeiro verso. A transposição feita de uma cidade para outra tem 'mudanças de tom' significativas: enquanto na primeira nenhuma lei do mundo decifra, na segunda toda lei do mundo oculta. Os três poemas-cidades seguintes a "Oyo", respectivamente "Kush", "Napata" e "Meroé", têm suas histórias interligadas, o que podemos perceber desde o início pelos subtítulos: "o surgimento do reino", "a primeira capital", "a nova capital". Kush o surgimento do reino No livro de G. Mokthar uma cidade pela primeira vez se erige com a lama. E o rio a circunda, e o Nilo a desce numa escadaria de musgo: uma única vez o livro de G. Mokthar falará na cidade escoando pelos ferimentos do Nilo. Napata a primeira capital A segunda palavra do livro de G. Mokthar é ainda uma cidade possuidora. Dois ou quantos reinos tenham se afogado nas estiagens do ouro e da madeira. Isso nunca é história nos compêndios a não ser quando o Nilo escoando funda o livro de G. Mokthar. Meroé a nova capital A segunda cidade afasta-se na floresta por não sentir o Nilo preenchendoa. A espessura do livro de G. Mokthar acumula o sumiço de outra cidade. A última estátua no livro de G. Mokthar seca ao sol de um reino extinto: o Nilo segue ferimentos. Vamos partir, inicialmente, de algumas informações históricas que podem nos auxiliar na compreensão dos poemas. O título do primeiro poema refere-se a Kush, o império que existiu entre o terceiro milênio antes da nossa era e o século IV, na Núbia, no vale do rio Nilo, região atualmente partilhada pelo Egito e Sudão. Acredita-se ter sido a civilização negra mais antiga da África. As primeiras sociedades estruturadas surgiram durante a primeira dinastia egípcia; durante a sexta dinastia (2246 a.C. a 2150 a.C.), os núbios estavam divididos em pequenos reinos. A unificação veio com o reino de Kerna. A cidade de 
Napata, localizada na margem oriental do Nilo, foi construída em 1450 a.C., aproximadamente. Trezentos anos mais tarde tornou-se a capital do reino de Kush. Após a expulsão dos kushitas do Egito, Napata continuou como residência real e centro religioso até aproximadamente o ano de 350, quando da dominação dos auximitas. Considerada Patrimônio Mundial pela UNESCO em 2003, Napata tem templos e palácios descritos por pesquisadores europeus desde a década de 1820. A nova capital dos núbios, Meroé, era mais próxima do Mar Vermelho. A escrita inventada pelos núbios, chamada meroítica, foi inventada durante o período de Meroé como capital do reino de Kush. Da nova capital os núbios dominaram o comércio entre a Arábia e a Europa. Os três poemas-cidade, "Kush", "Napata" e "Meroé" são todos atravessados pelo Nilo e pelo livro de G. Mokthar. Na verdade, o Nilo escoando é o que funda o livro de G. Mokthar, como vemos nos últimos versos de "Napata"; o Nilo funda o livro e vai levando consigo as cidades decadentes. Em "Napata" vemos o advérbio "ainda", no segundo verso, indicando tanto a semelhança com Kush, a cidade anterior, rica, portanto possuidora, quanto a noção de que Napata deixará de ser um núcleo poderoso, sucumbindo também à ruína. Em seguida temos: "Dois ou quantos reinos tenham se afogado/ nas estiagens do ouro e da madeira", e vemos o paradoxo de reinos que se afogam em estiagem, o que pode ser compreendido como reinos que pereceram devido à escassez dessas riquezas; a menção ao ouro nos remete à riqueza encontrada também em Ouro Preto e Johannesburgo, como veremos adiante. A parte do livro de G, Mokthar referente à África antiga é quase um compêndio de cidades e reinos que pereceram. A obra não registra uma "cidade possuidora" como Napata, a não ser quando esta escoa pelos ferimentos do Nilo. O que aparece no texto do estudioso não são as cidades em si, mas as ruínas, os restos, as feridas pelas quais se tenta recompor a imagem das cidades. Em "Napata", temos os versos 
"Dois ou quantos reinos tenham se afogado/ nas estiagens do ouro e da madeira./ Isso nunca é história nos compêndios/ a não ser quando o Nilo escoando/ funda o livro de G. Mokthar.": a história de Napata (e das outras cidades) só aparece devido ao que sobrou de seu afogamento que escoou pelo Nilo. Ainda que esteja se referindo à cidade textual moderna, um dos trechos de "Cidade: texto, labirinto, montagem", de Renato Cordeiro Gomes, ajuda-nos a ilustrar esse raciocínio, na parte em que se refere ao livro de registro da cidade: O livro é composto de pedaços, fragmentos, trechos apagados pelo tempo, rasuras - de textos que jamais serão recompostos na íntegra. As folhas, por outro lado, se superpõem, pois inscrevem cidades sucessivas, que por acaso têm o mesmo nome. Por isso, sua leitura se dá por aproximações, tentativas, rascunhos. A cidade construída pelo discurso possibilita visões diversas, leituras e interpretações que dependem do leitor, "o espaço exato em que se inscrevem, sem que nenhuma se perca, todas as citações de que uma escrita é feita" (GOMES, 1994, p. 24).

O que Cordeiro Gomes chama de livro de registro da cidade é uma reunião de diversos documentos, mapas, fotos, literatura, de materiais utilizados para fixar a memória da cidade. No que concerne ao livro de G. Mokthar, a memória das cidades da África antiga é escrita com os fragmentos restantes de documentos, esculturas, construções, o que talvez abra uma brecha ainda maior para a leitura dessas cidades feita pelo poeta, que une Kush (hoje chamada Kerna), Napata e Meroé não pelo laço histórico, como no livro de G. Mokthar, mas pela presença do Nilo, por onde as ruínas dessas cidades-poemas escoam.

Da África para as Minas Gerais, das cidades do reino de Kush para Macacos e Ouro Preto: 


\section{MACACOS}

o sentido das cidades históricas

Os homens são vulneráveis e as idéias deixam um rastro de impossível percepção. Estão abaixo todos os ossos e sobre eles os livros revelam minuciosamente: ardem. Os livros serão escritos nesta argila ao jeito de uma cidade inteira sobre um monte. (PEREIRA, 2002, p.38)

OURO PRETO roteiro de interpretações

Ao contemplar o barroco das igrejas e a rouquidão do ouro, o visitante olhar não funde o corpo ao tempo: outeiros tão escuros e não compreende o silêncio de um totem antes jamais percebido. O barroco não é o cansaço só ouro mas o direiro do explorado corpo. (PEREIRA, 2002, p.39)

Macacos é como é conhecido o distrito de Nova Lima, Minas Gerais, que tem como nome oficial São Sebastião das Águas Claras. A povoação começou em meados do século XVIII, tendo seu crescimento ligado à exploração do ouro (como Ouro Preto, antiga Vila Rica). Histórica e textualmente, a presença do ouro é importante nas duas cidades, seja no momento de sua fundação histórica, seja na sua permanência nas igrejas. Macacos e Ouro Preto tiveram seu crescimento diminuído com o fim do ouro, o que, de alguma forma, é como as cidades africanas afogadas em estiagem.

Saindo do Brasil e voltando à África, especificamente à África do Sul, temos três poemas: 


\section{SHAPERVILLE}

de saber que o mito de um homem

é mais forte que seu punho

O solfejo vem sobre o silêncio

maior é o seu sentido que as bandeiras

saudando os líderes e os códigos vazios.

Não importa por que solfejo anima

a um vivo mais que um discurso.

O solfejo de um pai junto aos seus mortos

torna-os cem anos relembrados.

(PEREIRA, 2002, p.39)

\section{JOHANNESBURGO}

Com a presença dos mais ausentes

é a vida seguindo

O incêndio é a mente do companheiro pousada no poema que há tempos é impossível completar: o incêndio grande sem chamas e grande como um tiro.

Há uma sombra razoável entre a árvore inexistente e o policial desapontado.

(PEREIRA, 2002, p.40)

\section{SOWETO}

o que parece frágil sabe reunir-se fortemente

O zinco espera a varanda que será mas a madeira não é toda para montar um abrigo de pétalas no jardim.

Por agora só a Constituição se contenta em saber os centímetros de um girassol. Um girassol é o sol colado ao zinco. (PEREIRA, 2002, p.40)

Shaperville é um bairro da África do Sul onde, durante uma manifestação nos anos 60 contra a lei do passe, uma das práticas do apartheid, policiais mataram 69 manifestantes negros desarmados. 
Johannesburgo é a maior cidade da África do Sul, tendo sido fundada em 1886 com a descoberta do ouro. É considerada a única cidade global africana. Nela se localiza a township de Soweto (South Western Township), criada para abrigar as populações negras que tiveram sua mudança forçada devido ao regime do apartheid.

Em 1976, o Conselho Representativo de Estudantes organizou um protesto contra o ensino da língua africâner, considerada opressora, nas escolas para negros. A polícia abriu fogo contra os manifestantes, e cerca de mil pessoas morreram no decorrer dos 12 meses seguintes, devido à violência que permaneceu após o protesto.

A primeira relação que estabelecemos com Johannesburgo é a ligação com Ouro Preto, advinda da exploração aurífera que alçou ambas à posição de destaque por conta do cobiçado metal. Assim como Napata, as demais cidades se afogam nas estiagens do ouro. As três regiões sulafricanas têm marcas causadas pela violência na luta contra o apartheid, mas as características representadas nos poemas estão ligadas ao que restou das lutas pela igualdade racial: em "Shaperville" o "mito de um homem" que aparece no subtítulo, assim como o solfejo que se sobrepõe ao silêncio, é mais significativo que bandeiras e símbolos, que torna os mortos lembrados durante cem anos; os ausentes presentes em "Johannesburgo"; o frágil unido que se torna forte em "Soweto", são elementos que ajudam na fixação da memória da luta anti-apartheid, na luta para que os gritos passados continuem a ecoar no presente.

Em seguida temos "Luanda":

\section{LUANDA}

ou por que uma cidade habita num homem

Os homens são banidos de sua terra e tornam com o tempo mais velho: são homens crescidos 
e sua vontade revendo a árvore que o vento concebeu em suas ausências: um oceano não adia um homem de sua árvore e a experiência que o amplia ensina-Ihe a orientação do mundo. (PEREIRA, 2002, p.42)

Em "Luanda", a ausência dos homens, banidos de sua terra de origem (historicamente, a maioria deixou o país devido à guerra civil angolana), mostra-nos o exílio. Luanda, a cidade que habita estes homens expatriados, passa a habitar o corpo dos homens, já que, em solo estrangeiro, o corpo acaba sendo a pátria dos exilados.

Em "Rio de Janeiro" e "Nova Orleans", as últimas cidades, os últimos poemas, a música ganha destaque:

\section{RIO DE JANEIRO}

que a música pode ser a vida

e isto é muito sério

A música das estações perdura nos sapatos e a verdade de um samba é a experiência de uma rua mal iluminada: aos sábados um bom dançarino está mais próximo da morte que uma estrela acesa sobre um hotel. Um compositor não samba para turistas e a vida não the parece o furo que o capitalista pensou para o surdo. (PEREIRA, 2002, p.41)

\section{NOVA ORLEANS}

como um canto transpõe a hipocrisia

A vida sabe o revés de uma tentativa mas o incêndio da voz atenua a solidão e o medo de um país incompreensivo. Arde para resistir ao não e revelar-se a alma que mais dentro do desespero percebe o mundo e seu absurdo: só um blue é justo e completo como um abraço. 
(PEREIRA, 2002, p. 42)

A importância da música em "Rio de Janeiro" é enorme: ela perdura, é de tal modo séria, que um compositor, que vive realmente próximo da música, e não do produto dela, como um capitalista, não explora o samba (um negócio bastante rentável, principalmente na cidade do Rio de Janeiro) vendendo-o e se vendendo para turistas; para o compositor, a relação existente com a música é bem diversa daquela pensada pelo capitalista.

Cidade multicultural, Nova Orleans tem influência francesa, espanhola e africana. Nela, a música serve como forma de ultrapassar a hipocrisia. Nota-se a polissemia presente no subtítulo do poema, no qual se lê "como um canto transpõe a hipocrisia". Como demonstrei na leitura de "Oyo" e "Salvador", a palavra transpor permite duas leituras. O canto pode ultrapassar a hipocrisia, mas também pode ser capaz de mudar-lhe o 'tom', alterando-Ihe a altura, a intensidade ou a duração. Quem sabe conseguindo modificar o 'tom', o caráter hipócrita.

A presença da cultura negra nesse conjunto de poemas é marcante. Ela aparece nas civilizações africanas de milênios antes de Cristo, que são nomes nos compêndios devido as suas ruínas. Surge também em "Oyo" e "Salvador", separadas pelo tempo e pelo espaço, mas unidas pela cultura iorubá (os escravos levados para a cidade de Salvador eram em sua maioria iorubás e nagôs). É perceptível também nos poemas das modernas cidades africanas, em suas lutas contra o preconceito e pela melhoria da vida de seus habitantes.

A música, que participa de alguns poemas e que percorre o livro todo, surge como uma forma de, em meio à mistura de influências, superar os problemas advindos da convivência de grupos distintos. Embora possa ser sentida, a presença desses fios condutores dos poemas 
não é apontada textualmente de forma a serem mais importantes do que os caminhos que o leitor pode traçar, mas estão inegavelmente presentes, o que faz dessa "presença ausente", porque se mostra e se esconde, algo mais forte e significativo, é claro sem que seja preciso dizê-lo. Como afirma Wim Wenders: "À medida que se deseja captar qualquer coisa para mostrá-la, é necessário se esforçar para não se deixar entrar na imagem. Aquilo que se quer mostrar, isso que se quer ter na imagem, explica-se pelo que se deixa de fora." (WENDERS, 1994, p.186).

Mas a presença aqui não é apenas afrodescendente, mas dos excluídos de um modo geral, do "explorado corpo" que aparece em "Ouro Preto". A lembrança de vozes que foram abafadas, como as das cidades descritas por G. Mokthar, dos manifestantes mortos na África do Sul, dos exilados angolanos, é mais do que um simples citar de nomes e datas, é um discurso desafiador.

Termino com a citação de entrevista de Fabrício Marques a Edimilson de Almeida Pereira:

Apagar a memória de certos mortos é mais do que um ato de displicência, pode ser um ato político, sobretudo quando, em vida, sua atuação, direta ou indiretamente, atirou pedras nas janelas de vidro; quando seu comportamento semeou rebeldia ou indicou outros caminhos além daqueles preestabelecidos. Por isso, o costume da opressão colonial de cortar cabeças e salgar a terra onde viveram os descontentes; por isso, a indiferença da sociedade moderna para com os espoliados e o interesse em apagá-los de suas páginas. (MARQUES, 2004, p.67) 


\section{CONCLUSÃO}

Ter nomeado este trabalho como "leituras das escolhas críticopoéticas" foi a alternativa encontrada para apontar como o projeto de Edimilson de Almeida Pereira se configura em três direções: antropologia, poesia, crítica. Tal projeto não precisa ter sido pensado da forma como se configura hoje para que tenha se desenvolvido de modo coeso e retroalimentar. A produção crítica não é desvencilhada do fazer poético: as personagens estão na margem da sociedade assim como o crítico que busca outras possibilidades e o poeta que insere outras estéticas (como a afrodescendente do Candombe).

Mesmo sendo capaz de lidar com o discurso do centro - e talvez por isso se trate de um trabalho tão consistente, já que para ele o desafio é "mapear essa outra configuração da poesia brasileira", a fala do poeta/crítico vem da margem. Ele ajuda a criar seu próprio espaco de inserção dentro da Literatura Afro-brasileira e, portanto, dentro da Literatura Brasileira.

A antropologia foi o meio no qual Edimilson Pereira foi premiado e reconhecido antes de que isso acontecesse enquanto poeta ou crítico. Embora atualmente sua produção seja mais concentrada nos textos poéticos, a antropologia serviu de caminho para conhecesse essa outra configuração, outras possibilidades estéticas. Pereira afirma em 
entrevistas, conforme demonstrado no decorrer desta tese, que o Projeto Minas \& Mineiros, que gerou resultados como Os tambores estão frios e Negras raízes Mineiras: os Arturos, foi importante para que ele entrasse em contato com outras expressões estéticas presentes na cultura afromineira, mas não exploradas, lidas, analisadas. A subsequente publicação de Árvore dos Arturos e Nós, os Bianos, aponta para uma poesia que tenta incorporar os novos elementos estéticos mas reconfigurados e criando o problema da classificação.

Os estudos antropológicos constituem uma das chaves para se adentrar na poesia de Pereira, sem a qual é difícil entender as referências aos ritos, cantos e crenças que aparecem nos poemas. Mas o trabalho como antropólogo acabou fomentando, também, o trabalho do crítico: a proposta de ler os cantopoemas não como manifestações folclóricas ou apenas cantos religiosos, abriu outra possibilidade, a de inseri-los como produções poéticas afro-brasileiras. Quando a leitura dos cantopoemas é feita para além da leitura antropológica, inserida no meio poético, a marcação do reconhecimento artístico não valoriza apenas aquela produção, mas problematiza as instâncias que negam esse reconhecimento.

Desde os primeiros contatos com a obra de Edimilson Pereira, a complexidade de sua produção poética foi um dos meus maiores desafios, mas não tão grande quanto tentar pensá-lo no cenário literário brasileiro. A leitura frequente de Pereira como poeta afro-brasileiro parecia condicioná-lo a uma categoria dentro da literatura que implica mais restrição do que classificação, algo que não me parece coerente com sua produção, tão voltada para a abertura e o diálogo com outras obras que não necessariamente afrodescendentes. Percebo hoje que a produção de Edimilson Pereira, como poeta e como crítico, problematiza a Literatura Brasileira e mais ainda a Literatura Negra e/ou Afro-brasileira, pois 
questiona a marcação histórica e ideológica apreciada pelos críticos da produção afrodescendente, que por vezes coloca de lado as características do discurso poético, o elemento estético do texto literário. Não há, na poesia de Pereira, a necessidade de escolher entre a elaboração estética e as interpretações do real, pelo contrário: o projeto poético do autor revela a mescla desses aspectos, o que destoa diante de discursos engessados.

A produção de Pereira aponta para a criação - ou conquista - de um território no qual a Literatura Afro-brasileira não precise se ater às denúncias da situação extra poética dos afrodescendentes. Embora esta não seja uma questão a ser ignorada, o cerceamento que por vezes gera impede que experimentações estéticas sejam feitas, que autores não afinados com determinadas ideologias sejam ouvidos. No jogo dicotômico entre produção literária de cunho político e elaboração estilística, pender para um só lado é um risco que inibe que mais vozes sejam ouvidas.

Os tópicos sobre uma História da Literatura Afro-brasileira que Edimilson Pereira vai apontando em seus textos críticos não excluem os autores que abordaram ou pouco ou de modo menos contundente a situação social dos afrodescendentes no Brasil. E suas marcações de leitura não ficam nem no Brasil nem na estética européia, nem na busca de uma África mítica: o encontro com os poetas caribenhos, músicos cubanos e argentinos, bluesmen norte-americanos, tudo indica não para um fechamento ou um retorno, mas assinala as trocas possíveis entre outros buriladores da palavra dentro da diáspora. 


\section{REFERÊNCIAS BIBLIOGRÁFICAS}

ALBERTSON, Chris. Bessie. Rev. and exp. edition. Yale University Press and New Haven \& London: 2003.

ALEIXO, Rique. "Viagem à textualidade afro-mineira". IN: Suplemento Literário de Minas Gerais. Belo Horizonte: No1113, Sábado, 07/01/1989.

. "A roda do mundo é grande mas Oxalá é maior". Oroboro, n 05, setembro de 2005. Entrevista concedida a Ricardo Corona. Disponível em <http://blogdocorona.blogspot.com/2011_05_01_archive.html>. Acesso: 14 de nov. de 2013.

AVELAR, Idelber. "Cânone literário e valor estético: notas sobre um debate de nosso tempo. In: Revista Brasileira de Literatura Comparada, n015, 2009, pgs.113-150.

BANDEIRA, Manuel. Estrela da vida inteira. Introdução de Gilda e Antonio Candido de Mello e Souza. Rio de Janeiro: José Olympio, 1983.

BARBOSA, Maria José Somerlate. "'Dançar o nome com o braço na palavra berço': A relação vida e obra poética". In: Scripta, Belo Horizonte: Editora UFMG, v.15, n.29, p.235-262, 2011.

- "Com modos e truques de ouvir: entrevista com Edimilson de Almeida Pereira". Brasil/Brazil: Revista de Literatura Brasileira/ Journal of Brazilian Literatura. Porto Alegre, EDIPUCRS, 1998, p.98-130.

BASTIDE, Roger. A poesia afro-brasileira. São Paulo: Livraria Martins Fontes, 1943.

BERND, Zilá (org.). Antologia de poesia afro-brasileira: 150 anos de consciência negra no Brasil. Belo Horizonte: Mazza Edições, 2011.

BLOOM, Harold. O cânone ocidental. Tradução de Marcos Santarrita. Rio de Janeiro: Objetiva, 2010. 
BUEHRER, Ted. How to Listen to and Appreciate Jazz. Course guide. Kenyon College: Recorded Books, 2006.

CAMPOS, Mara Consuelo Cunha. "Cruz e Sousa". In: DUARTE, Eduardo de Assis (org.). Literatura e afrodescendência no Brasil: antologia crítica. Belo Horizonte: Editoda UFMG, 2011. Pg. 223-25.

CASANOVA, Pascale. A República Mundial das Letras. Tradução de Marina Appenzeller. São Paulo: Estação Liberdade, 2002.

CRUZ E SOUSA, João da. Obra Completa. Rio de Janeiro, Editora José Aguilar, 1961.

- Cruz e Sousa. Seleção de textos, notas, estudos biográficos e crítico por Aguinaldo José Gonçalves. 2 edição. São Paulo: Nova Cultural, 1988.

CUNHA, Celso. Nova gramática do português contemporâneo. Rio de Janeiro: Nova Fronteira, 1985.

CUTI (Luiz SILVA). Literatura negro-brasileira. São Paulo: Selo Negro, 2010.

DELEUZE, Gilles \& GUATTARI, Félix. Mil platôs: capitalismo e esquizofrenia. Volume 5. São Paulo: Editora34, 1007.

Dicionário Priberam da Língua Portuguesa [em linha], 2008-2013. Disponível em: http://www.priberam.pt/dlpo/. Acesso: 09 de jan. De 2014.

DUARTE, Eduardo de Assis. "A capoeria literária de Machado de Assis". Portal Liteafro. Acessado em 18 de jun. De 2014. Disponível em $<$ http://www.letras.ufmg.br/literafro/data1/autores/98/machadocritica08. pdf>

ECHOLS, Alice. Scars of sweet paradise: the life and times of Janis Joplin. New York, Holt Paperbacks, 2000.

EVANS, David. "Bessie Smith's 'Back-Water Blues': the story behind the song". In: Popular music. Volume 26, Issue 01, January 2006, pp. 97-116. Published online 04 January 2007. Disponível em <http://journals.cambridge.org/abstract_S0261143007001158>. Acessado em 28 de abril de 2014.

GILROY, Paul. O Atlântico negro. Tradução de Cid Knipel Moreira. São 
Paulo: Ed. 34; Rio de Janeiro: Universidade Cândido Mendes, Centro de Estudos Afro-Asiáticos, 2001.

GOMES, Núbia Pereira de Magalhães e PEREIRA, Edimilson de Almeida. Mundo encaixado: significação da cultura popular. Belo Horizonte: Mazza Edições, 1992.

GOMES, Renato Cordeiro. Todas as cidades, a cidade: literatura e experiência urbana. Rio de Janeiro: Rocco, 1994.

GULLAR, José Ribamar Ferreira. "Preconceito cultural". Caderno Ilustrada, Jornal Folha de S. Paulo. São Paulo, domingo, 04 de dezembro de 2011. Disponível em http://www1.folha.uol.com.br/fsp/ilustrada/12790preconceito-cultural.shtml. Acesso: 09 de abril de 2014.

HOBSBAWN, Eric. História Social do Jazz. Tradução de Angela Noronha. São Paulo: Paz e Terra, 2010.

- Pessoas extraordinárias: resistência, rebelião e jazz. Tradução de Irene Hirsch, Lólio Lourenço de Oliveira. São Paulo: Paz e Terra, 1998.

HOUAISS, Antônio e VILLAR, Mauro de Salles. Dicionário Houaiss da Língua Portuguesa. Rio de Janeiro, Objetiva, 2001.

JAHN, Janheinz. A History of Neo-African Literature. London: Faber, 1968.

JAMES, Henry. "A figura no tapete". In: . A morte do leão. Tradução de Paulo Henriques Brito. Companhia das Letras: São Paulo, 1993.

LEITE, Sebastião Uchoa. "Invenção a várias vozes de Edimilson de Almeida Pereira". In:

LEMINSKI, Paulo. Cruz e Sousa: O negro branco. São Paulo: Brasiliense, 2003. Coleção Encanto Radical.

LOBO, Luiza. Crítica sem juízo. Rio de Janeiro: Francisco Alves, 1993.

LUCAS, Fábio. "Panorama da Poesia Brasileira Contemporânea". Disponível em: http://armazem.literario.nom.br/convidados/18_fabiolucas.htm. Acesso em Jan.2014.

LUCAS, Glaura. Os sons do Rosário: o congado mineiro dos Arturos e Jatobá. Belo Horizonte: Editora UFMG, 2002.

MACHADO FILHO, Aires da Mata. O negro e o Garimpo em Minas Gerais. 
São Paulo: Editora da Universidade de São Paulo, 1985. Série Reconquista do Brasil, v.88.

MARTINS, Nilce Sant'anna. Introdução à Estilística: a expressividade na Língua Portuguesa. 4a edição,

OLIVEIRA, Fabrício Marques de. Dez conversas - diálogos com poetas contemporâneos. Belo Horizonte: Gutenberg, 2004.

OLIVEIRA, Eduardo de Oliveira e. "O mulato, um obstáculo epistemológico". In: Argumento. Rio de Janeiro, ano 1, n03, pg.65-74, Jan. de 1974.

O'NEALE, Sondra A. "Phillis Wheatley". Disponível em: http://www. poetryfoundation.org/bio/phillis-wheatley. Acesso: 09 de dez. De 2013.

PADILHA, Laura Cavalcante. Novos pactos, outras ficções: ensaios sobre literaturas afro-luso-brasileiras. Porto Alegre: EDIPUCRS, 2002 (Coleção Memória das Letras/10).

"Palo (religião)". In: Wikipedia. Acessado em 23 de janeiro de 2012. Disponível em http://pt.wikipedia.org/wiki/Palo_(religi\%C3\%A3o); http://www.wikidominicana.edu.do/wiki/Cimarronaje Acesso: 07 de dez. de 2010.

PEREIRA Edimilson de Almeida; GOMES, Núbia Pereira de Magalhães; PEREIRA, Marcelo. Arturos: olhos do Rosário. Belo Horizonte: Mazza Edições, 1990.

PEREIRA, Edimilson de A. Zeosório Blues. Obra poética 1. Belo Horizonte: Mazza Edições, 2002. 2003a. 2003b.

. Lugares Ares. Obra poética 2. Belo Horizonte: Mazza Edições,

Casa da Palavra. Obra poética 3. Belo Horizonte: Mazza Edições, . As Coisas Arcas. Obra poética 4. Juiz de Fora: Funalfa Edições, 2003c.

. "Poesia no meio da rua, no meio do mar: notas sobre ritualidade e estética na cultura afro-brasileira" In: NASCIMENTO, Evando; OLIVEIRA, Maria Clara Castellões de; SILVA, Teresinha Zimbrão da. Literatura em 
perspectiva. Juiz de Fora: Editora UFJF, 2003d.

Os tambores estão frios: herança cultural e sincretismo religioso no ritual de Candombe. Belo Horizonte; Juiz de Fora: Mazza Edições e Funalfa Edições, 2005a.

. Signo cimarrón. Belo Horizonte: Mazza Edições, 2005b.

. "O movimento literário em Juiz de Fora nos anos 80". In: FARIA, Alexandre (org.). Poesia e vida: anos 70. Juiz de Fora: Editora da UFJF, 2007.

. "Territórios cruzados: relações entre cânone literário e literatura negra e/ ou afro-brasileira." In: PEREIRA, Edimilson de Almeida \& DAIBERT JÚNIOR, Robert (orgs.). Depois, o Atlântico: modos de pensar, crer e narrar na diáspora africana. Juiz de Fora: Editora UFJF, 2010a.

- Homeless. Belo Horizonte/Juiz de Fora: Mazza Edições/Sans Chapeau, 2010b.

- Malungos na escola: questões sobre culturas afrodescendentes e educação. São Paulo: Paulinas, 2010c.

- Variaciones de un libro de sirenas. Belo Horizonte/Juiz de Fora: Mazza Edições/Sans Chapeau, 2010c.

. "Cantopoemas: uma literatura silenciosa no Brasil"; "Negociação e conflito na construção das poéticas brasileiras contemporâneas". In: PEREIRA, Edimilson de Almeida (org.). Um tigre na floresta de signos: estudos sobre a poesia e demandas sociais no Brasil. Belo Horizonte: Mazza Edições, 2010d. Coleção Setefalas.

. "Entrevista - Edimilson de Almeida Pereira: como modos e truques de ouvir". In: Brasil/Brazil: Revista de Literatura Brasileira/ A Journal of Brazilian Literature. EDIPUCRS. No19, ano 11, 1998. Entrevista concedida a Maria José Somerlate Barbosa.

PERRONE-MOISÉS, Leyla. Altas literaturas: escolha e valor na obra crítica de escritores modernos. São Paulo: Companhia das Letras, 1998.

. "Literatura para todos". In: Revista Literatura e Sociedade. N.09. Departamento de Teoria Literária e Literatura Comparada. São Paulo: USP/FFLCH/DTLLC, 2006.

"Prémio Camões". In: Direção Geral do Livro, dos Arquivos e das 
Bibliotecas. Secretário de Estado da Cultura. Governo de Portugal. Disponível em <http://www.dglb.pt/sites/DGLB/Portugues/premios/Paginas/PremioDetal he. aspx?PremioId=61>. Acesso em 23 de abril de 2014.

RESENDE, Beatriz. Apontamentos de crítica cultural. Rio de Janeiro: Aeroplano, 2002.

ROCHA, Enilce Albergaria. "No fio da navalha". In: Estado de Minas Gerais. Caderno Pensar. Belo Horizonte: 20 de dezembro de 2003, p.4.

ROWELL, Charles \& SILVA, Luiz (Cuti). "Uma entrevista". In: Callaloo, Vol. 18, n. 4, Literatura Afro-Brasileira: Um Número Especial (Autumn, 1995), pp. 901-904. Johns Hopkins University Press.

RUFFATO, Luiz (org.). Questão de pele. Rio de Janeiro: Língua Geral, 2009.

SAUSSURE, Ferdinand. Curso de Linguística Geral. Tradução de Antônio Chelini, José Paulo Paes e Izidoro Blikstein. São Paulo: Cultrix, 1995.

SILVA, Daviane Moreira e. "Césaire-Pereira: uma leitura Martinica-Brasil". In: Revista Crioula, n.06, 2009. Disponível em http://www.revistas.usp.br/crioula/article/view/54970. Acesso em 25 de março de 2014.

SILVA, Luiz (Cuti). "A empáfia do poeta Gullar". In: Geledés Instituto da Mulher Negra. Publicado em 08/12/2011. Disponível em http://www.geledes.org.br/em-debate/colunistas/12190-luiz-silva-cuti-aempafia-do-poeta-goulart. Acesso em 09/04/2014.

SILVA, Luiz. Um desafio submerso: evocações, de Cruz e Sousa, e seus aspectos de construção poética. Dissertação de mestrado. Instituto de Estudos da Linguagem, Universidade Estadual de Campinas, 2008.

SILVA, Geraldo da \& ARAúJO, Márcia. "Da interdição escolar às ações educacionais de sucesso: escolas dos movimentos negros e escolas profissionais, técnicas e tecnológicas". In: História da Educação do Negro e outras histórias. ROMÃO, Jeruse (org.). Secretaria de Educação Continuada, Alfabetização e Diversidade. - Brasília: Ministério da Educação, Secretaria de Educação Continuada, Alfabetização e Diversidade. 2005.

SOARES, Iaponan. Ao redor de Cruz e Sousa. Florianópolis: Editora da 
UFSC, 1988.

SOUZA, Florentina \& LIMA, Maria Nazaré (org.). Literatura Afro-Brasileira. Salvador: Centro de Estudos Afro-Orientais; Brasília: Fundação Cultural Palmares, 2006.

SPADA, Fred. Juiz de Fora - História lírica: 2, Edimilson de Almeida Pereira. Depoimento concedido a Frederico Spada. Disponível em http://www. youtube.com/watch?v=4XKuNRttvyI\&feature=plcp. Acesso: 28 de maio de 2012.

THE BLUES. Feel like going home. Direção: Martin Scorsese. Produção: Sam Pollard. Roteiro: Peter Guranilk. São Paulo: Focus Filmes, 2003, 1 DVD.

VERGER, Pierre Fatumbi. Os Orixás. Salvador: Corrupio, 2002.

WHITE, Steve. "An Interview With Edimilson de Almeida Pereira". Callaloo, volume 19, no 1, Winter 1996. The John Hopkins University Press. p.4454. Disponível em http://www.jstor.org/stable/3299318. Acesso em 24/04/2012. 


\section{ANEXO 1}

\section{APRESENTAÇÃO dOS VOLUMES DE POESIA DE EDMILSON DE ALMEIDA PEREIRA}

Os livros de poesia escritos anteriormente começaram a ser reorganizados no início dos anos 2000, o que deu origem aos quatro volumes poéticos que compunham o corpus original da pesquisa: os poemas inéditos ou não foram combinados de modo que se percebesse similaridades estilísticas e temáticas.

PEREIRA, Edimilson de Almeida. Zeosório Blues. Obra poética 1. Belo Horizonte: Mazza Edições, 2002.

A primeira reunião poética, Zeosório blues, de 2002, percorre vários cenários: dos locais da infância aparecerem as casas da família, os quintais próprios e dos vizinhos, o campinho, as ruas do bairro, as avenidas de Juiz de Fora; além desses, os ambientes de produção e compartilhamento musical, como as quadras de escolas de samba, gafieiras, clubes de música, bares. Soma-se ainda os poemas sobre antigos reinos africanos, os bairros e capitais da África contemporânea, as cidades históricas do Brasil que receberam grande quantidade de africanos escravizados.

A dicção presente em Zeosório Blues mostra-se clara desde o título; mais exato do que falar em diç̧ão talvez seja se referir aos 'ritmos' deste 
primeiro volume, do qual destacamos dois aspectos: a música e seus entornos, que percorrem todo o livro e podem ser rastreados também nos outros livros (representados nos poemas pela dança, pelos ensaios nas quadras de escola de samba, pela mulher que estuda a voz, o músico que mora sozinho); e é a diç̧ão, no sentido dicionarizado de "modo de dizer, no que tange à escolha e à combinação e disposição das palavras, com vista à correção, clareza e eficácia do texto" (HOUAISS, 2001, p. 1034). Neste caso, a voz que se ouve articular as palavras adéqua a pronúncia aos sujeitos líricos presentes nos textos, geralmente produtores de música, com a aglutinação, na escrita poética, de termos unidos na linguagem oral, como nos versos "na banda/ o ritmo da cidade/ quiéssa é maravilhosa" (PEREIRA, 2002, p.23), priorizando o som que mantém o ritmo do poema. As variantes musicais e os personagens que surgem são originários das camadas populares, daí o possível interesse em mostrar a cadência da linguagem falada através da adequação da forma escrita, identificável no título do livro, que opta por Zeosório no lugar de José Osório, o que permite que o deslisar do som chegue mais prontamente ao leitor.

A escolha de Drummond para "abrir" O Lapassi \& Outros Ritmos de Ouvido aparece com a pergunta vinda de "Especulações em torno da palavra homem": o poema não funciona só como epígrafe para este livro, mas pode ser uma das linhas de leitura para toda obra.

PEREIRA, Edimilson de Almeida. Lugares Ares. Obra poética 3. Belo Horizonte: Mazza Edições, 2003.

Lugares ares, de 2003, abarca exemplos das duas décadas de produção poética, trazendo o primeiro livro, Dormundo (cujos temas vão do cotidiano de solidão e desalento à multiplicidade contida nas palavras) e Blanco, então inédito, que compartilha com Águas de Contendas o gosto 
dos lugares que se visita; além desses lemos o encontro amoroso em Corpo imprevisto, os enigmas e embaixadores de Rebojo (explicar quem sao estes embaixadores e porque sao importantes). O livro Águas de Contendas, na organização da reunião poética de Edimilson de Almeida Pereira, juntou-se ao segundo volume, Lugares Ares, e reúne poemas nos quais o cenário mineiro se faz presente em diferentes momentos históricos, do "Quarto de moça no século XVIII", que reúne quatro poemas indicativos do universo feminino pré-nupcial com um "Oratório" no qual Santa Bárbara "calma/tormentas/de águas e mágoas", enquanto em "Roda de fiar" a noiva agiliza a confecção da manta na qual o futuro marido "depois de imundiçar o mundo/limpará a alma", ou ainda a "Vigília" da moça cujo "O pai tem seu mando/ em cavalos e mantas./Nos desejos não.". Nesse conjunto de poemas percebemos a reconstrução de um cenário em que, conforme destacado no primeiro deles, o tempo volta mas demonstra que sob o recato da moça que não ergue os olhos diante do pretendente, há o desejo revelado na observação de mãos e ombros masculinos, desejo esse que nem o pai, nem o anjo da guarda conseguem conter (PEREIRA, 2003, p. 139-40). Dos quartos do século XVIII e das cartas escritas em respostas a ofícios pode-se transitar para os dias atuais, percorrendo as partes mais diversas do mundo, desde cidade do interior de Minas Gerais, como Lagoa de Santo Antônio, na qual "Boi no carro ajunta contas pessoais" (idem, ibidem, p.191), passando por Dublin, "onde um brasileiro estuda iorubá." (idem, ibidem, p.160), enquanto o leitor ouve a voz de Cesária Évora cantando em Cabo Verde ecoar em Praga, em casas alemãs, e nos subúrbios de Belo Horizonte (p.193).

PEREIRA, Edimilson de Almeida. Casa da Palavra. Obra poética 3. Belo Horizonte: Mazza Edições, 2003b.

Em 2003 foi lançada a terceira reunião poética, Casa da palavra, 
sobre a qual é importante destacar que, enquanto as referências críticas e literárias aparecem frequentemente no decorrer das outras reuniões poéticas, os livros ou sessões que recriam ritos ou celebrações do Candombe, lendas africanas, enfim, que de algum modo têm como principais elementos de criação o saber tradicional de comunidades ou grupos étnicos menos contemplados nos estudos e escritas que se utilizam da matriz africana, não aparecerem mesclados a citações de obras da cultura escrita. Na esfera familiar e dos antepassados, vemos o retorno à nação de origem através da transcriação das lendas e dos mitos de diversas etnias africanas: a criação do homem por Mbere (Bantu), o morto que deve ser levado para o outro lado do rio; aproximando-se das crenças ainda vigentes de se enterrar o umbigo do recém-nascido perto de porteiras para crescer forte ou de roseiras para garantir a beleza da criança. A família é eixo importante das intermediações sociais ( $v$. Na senzala, uma flor para pensar isso no corpo do texto da tese), providenciando a benzição, rezando o terço, proporcionando o aprendizado; até mesmo nos nomes podemos ler os laços existentes em uma identidade constituída pelas relações sociais de parentesco e matrimônio: vemos o nome de Zé da Ernestina (por ser dela marido), com o consorte sendo conhecido pela relação com a mulher, e não o contrário, Terezinha de Nélson de Jacó (Terezinha casada com Nélson, filho de Jacó), nomeação que consegue elencar a relação de parentesco de três pessoas: no discurso de diminuição do negro, a família é resistência à reificação.

PEREIRA, Edimilson de Almeida. As Coisas Arcas. Obra poética 4. Juiz de Fora: Funalfa Edições, 2003.

A reunião seguinte, também de 2003, As coisas arcas, traz algumas das chaves para se adentrar nesse universo poético tão recheado de personagens, de links com outros contextos diaspóricos que não o 
brasileiro, como os "Três tigres", três narradores da vida de escravos nas Américas ( $p .173$ ), ou o vertiginoso e circular [lembrar da cobra engolindo o proprio rabo] "Caderno de retorno", que se inicia e termina com a pele que interessa, aquela "que se arrisca ao texto e refuta a tese" (p.241), dialogando com o Cahier d'un retour au pays natal do martinicano Aimé Césaire, diálogo esse tratado durante nossa dissertação de mestrado.

PEREIRA, Edimilson de Almeida. Signo cimarrón. Belo Horizonte: Mazza Edições, 2005.

O primeiro livro lançado após as reuniões poéticas, Signo cimarrón, traz no nome a relação que constrói com a afrodescendência na América Latina, seja pelo espanhol como língua escolhida, seja pela eleição do cimarrón como símbolo da resistência à escravidão.

PEREIRA, Edimilson de Almeida. Variaciones de un libro de sirenas. Belo Horizonte/Juiz de Fora: Mazza Edições/Sans Chapeau, 2010.

O livro trabalha a temática do exílio representado não apenas pela dispersão física, mas também linguística (o livro também foi escrito em espanhol), em meio ao ambiente maravilhoso habitado por sereias e kiandas.

PEREIRA, Edimilson de Almeida. Homeless. Belo Horizonte/Juiz de Fora: Mazza Edições/Sans Chapeau, 2010.

Em Homeless, a 'abertura' das três partes que formam o livro vem da reconfiguração de outros poemas [poeta esta realmente relendo sua obra]; as diásporas africanas e as elaborações estéticas surgidas do tema se fazem bastante presentes nesta última obra, bem como um estreitamento entre a antropologia e a poesia. 


\section{ANEXO 2}

\section{TABELA TEMÁTICA}

A tabela que segue foi feita no início do doutoramento, em 2010, e complementada em 2012, quando tive acesso aos dois livros de poesia mais recente de Edimilson de Almeida Pereira, Variaciones de un libro de sirenas e Homeless. O objetivo principal era realizar um levantamento dos temas, expressões, imagens e referências recorrentes na obra de Pereira para, através deles, melhor definir o corpus poético a ser analisado. Não há intenção de esgotar todas as referências possíveis, mas tal levantamento auxiliou bastante na hora de observar algumas particularidades e obsessões de Pereira, no sentido de temas e expressões sempre retomados em sua extensa obra. O procedimento mostrou-se útil pela gama de ligações que percebi entre os livros e, principalmente, entre Pereira e outros artífices da palavra. E, qual não foi a minha surpresa ao perceber que o livreto que acompanha Homeless (excerto Anexo 3) serve para apontar mais claramente algumas dessas referências, mais difíceis de serem identificadas.

Alguns esclarecimentos sobre a tabela que apresento devem ser feitos: em "Referências Literárias/Teatrais", apontei menções a autores, versos, livros e peças que pude reconhecer. Embora expressões do "Sagrado" (coluna G) possa ser lido como "Marcas culturais" (coluna H), destaquei as alusões às religiões afro-descendentes pela frequência e importância que assumem na obra. Em "Poética/Linguagem" (coluna I), 
reuni os poemas nos quais encontrei reflexões sobre o fazer poético e a linguagem, o que auxiliou no recorte para a leitura dos metapoemas do Capítulo 2. Sob o nome de "Índices" (coluna L), reuni algumas das repetições que aparecem na obra, e entre eles optei pela leitura mais detalhada de "Orfeu" e "Ira" cujas possibilidades de análise apresentei no Capítulo 3. 


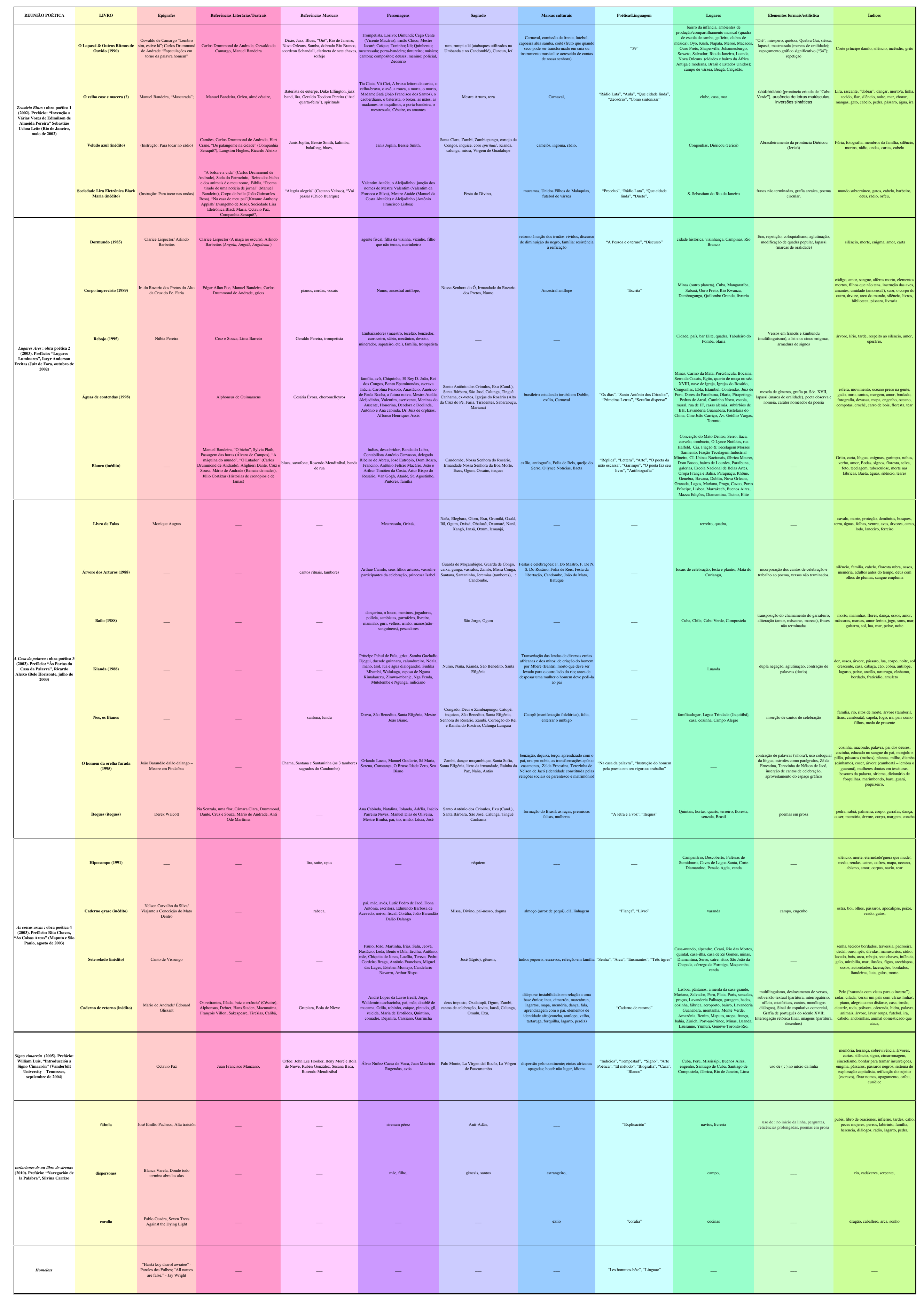




\section{ANEXO 3}

EXCERTO LIVRETO HOMELESS

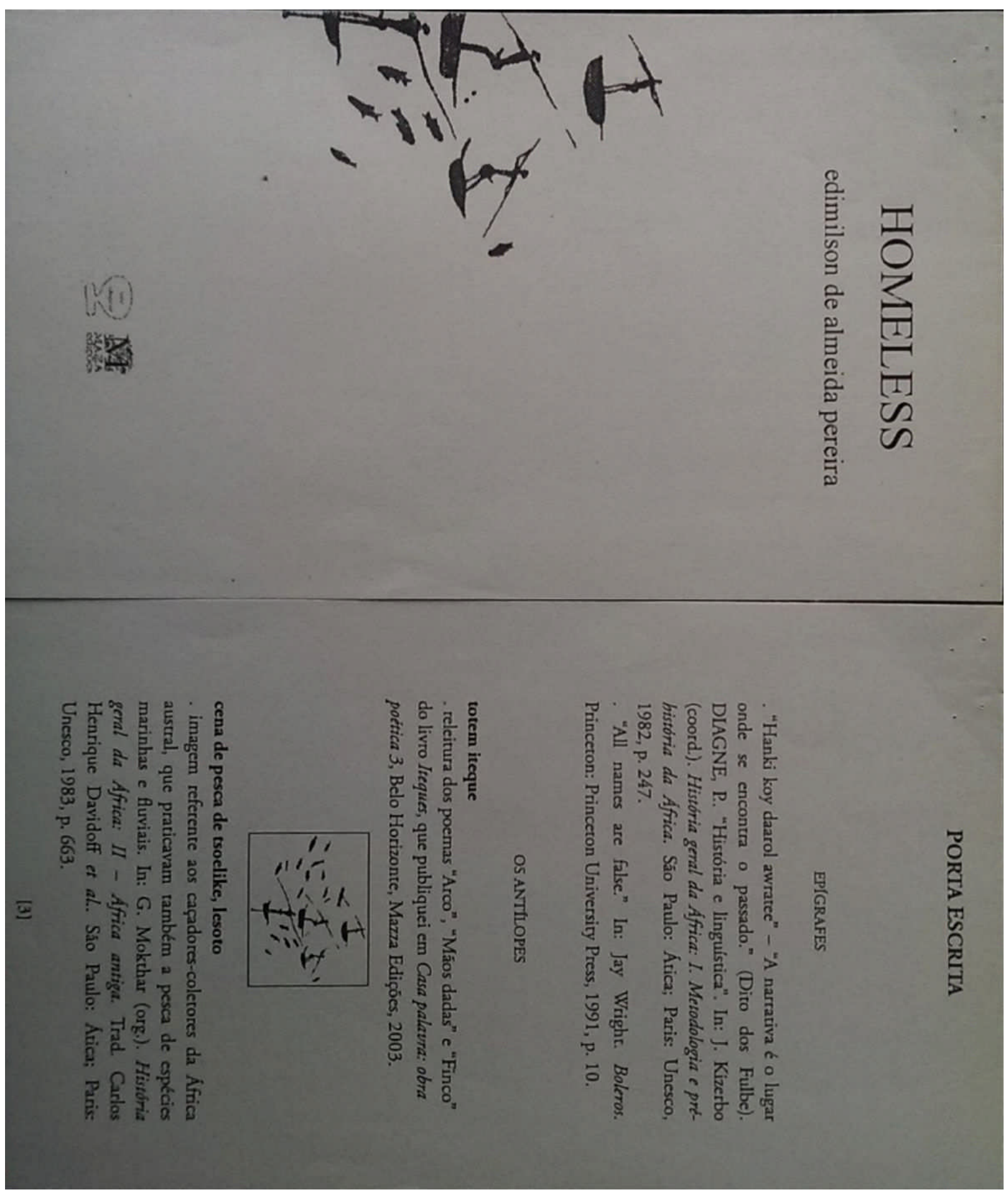

